Historic, Archive Document

Do not assume content reflects current scientific knowledge, policies, or practices. 



\section{LUXEMBURG HARDY}

Best Copper Yellow Rose

No. 1, 2 Years, Lang's Special.
FRAU K. DRUSCHKI

The Largest Pure White Rose Grown No. 1 Lang's Quality, 2 Years

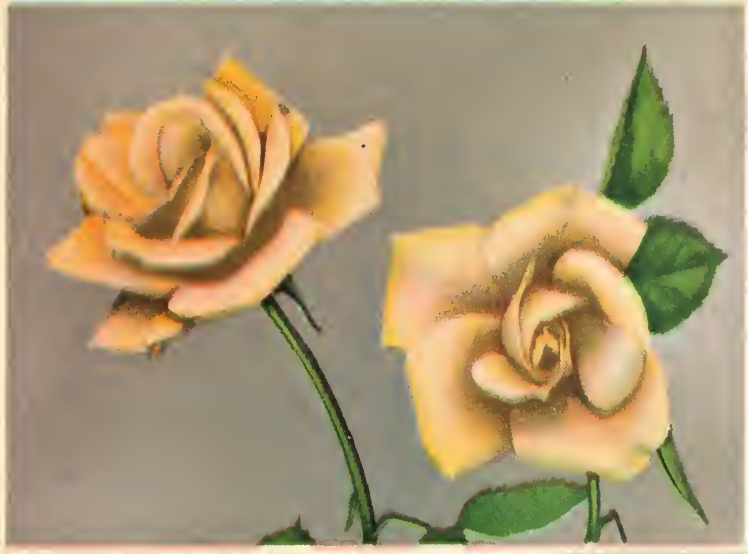

American Beauty

2-Year Plants, No. 1 Lang's quality
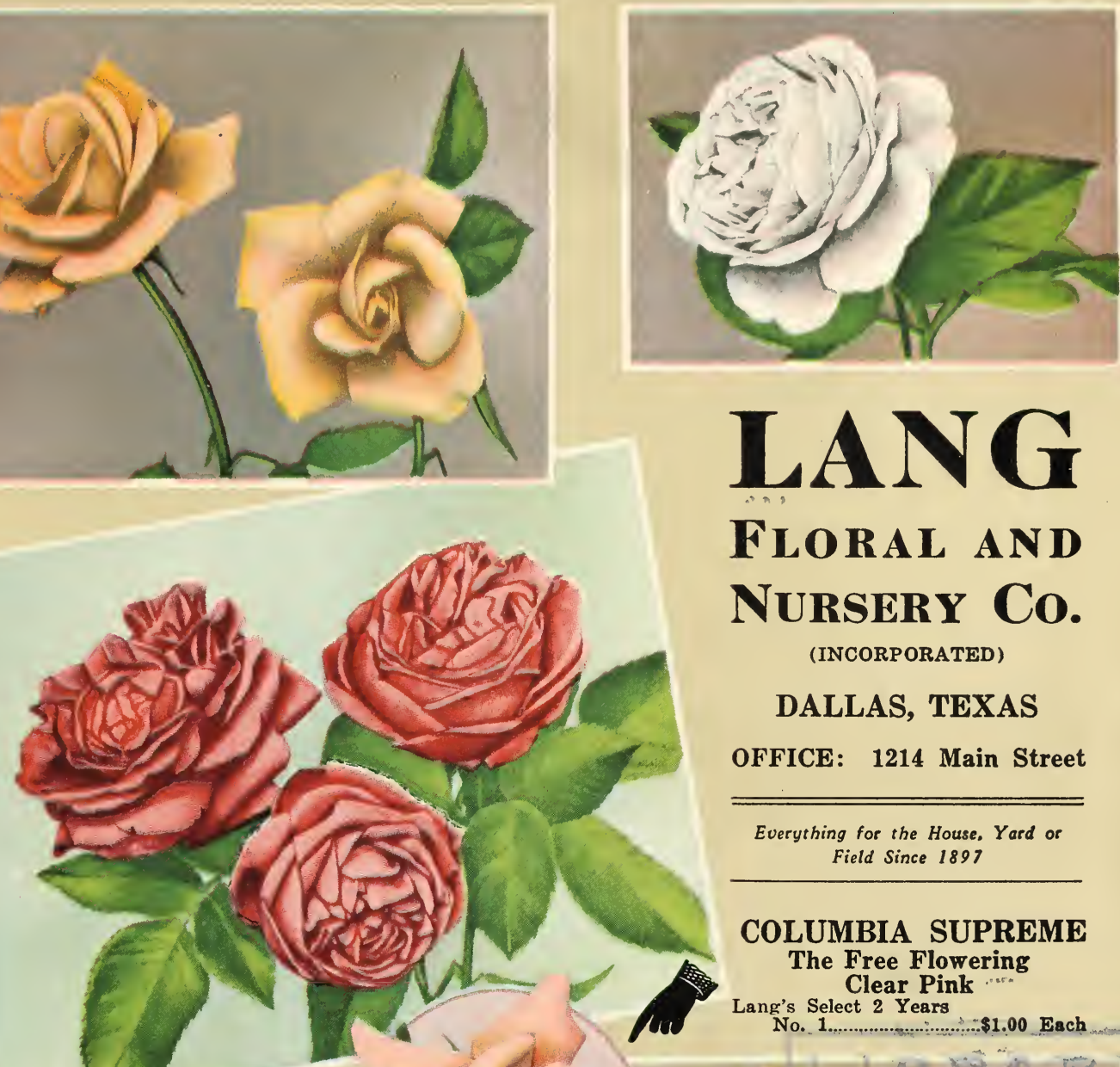

\section{Floral and NURSERY Co.}

(INCORPORATED)

DALLAS, TEXAS

OFFICE: 1214 Main Street

Everything for the House, Yard or Field Since 1897

COLUMBIA SUPREME

The Free Flowering Clear Pink

Lang's Select 2 Years

No. 1.......................... \$1.00 Each

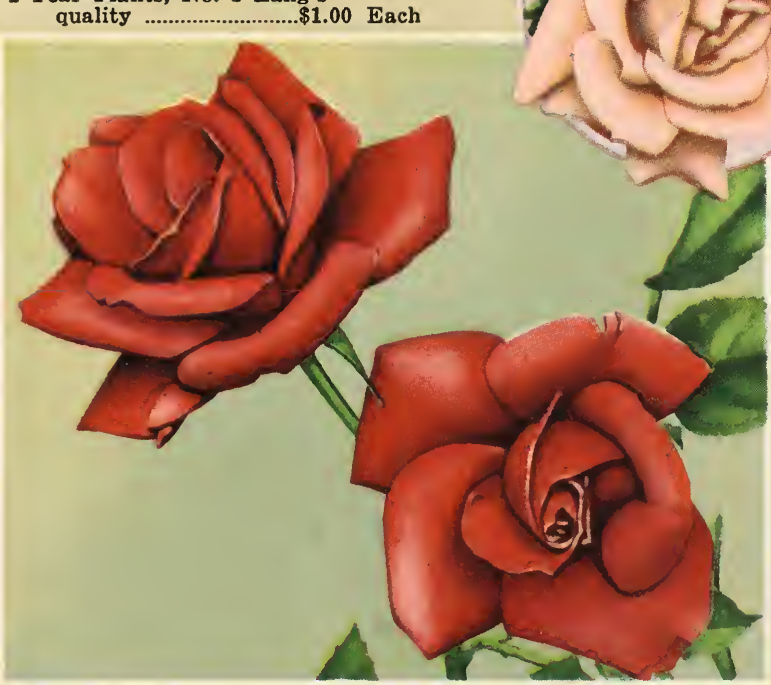

IMPROVED RED RADIANCE

The South's Best Red Rose

Lang's Special 2-Year No. 1 .
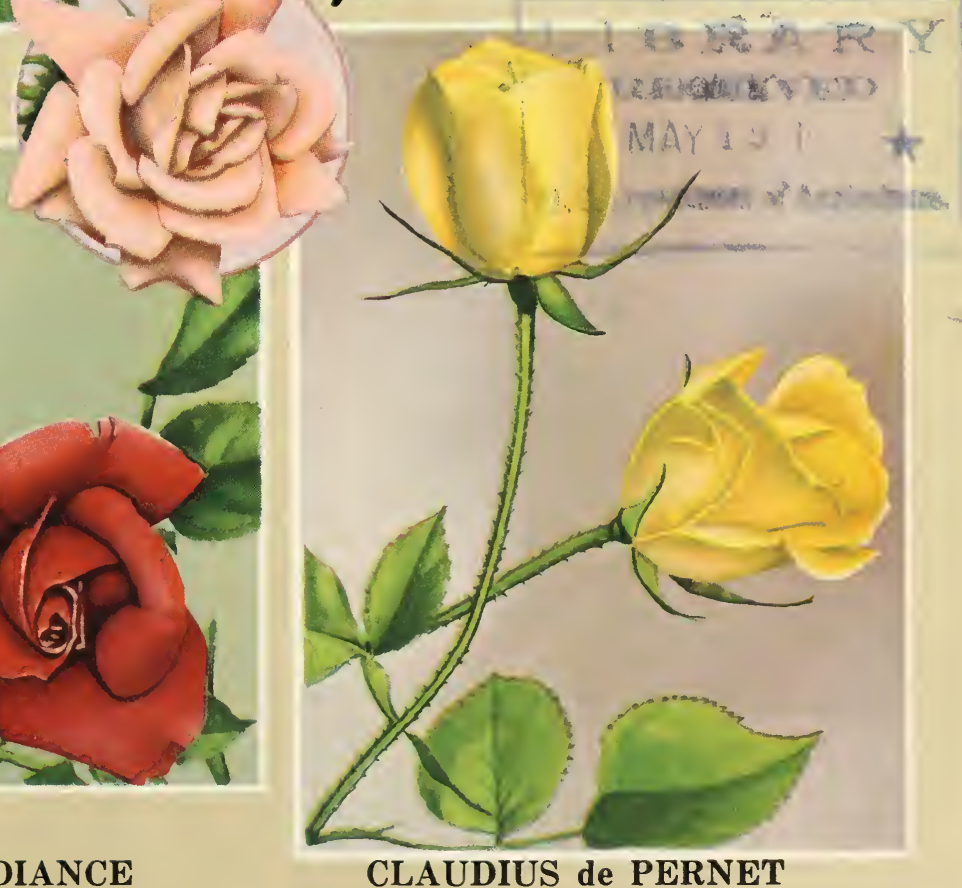

The Finest Pure Yellow Long Bud to Date 2-Year No. 1 Lang's Special............................\$2.00 Each 


\section{HOLLYHOCK}

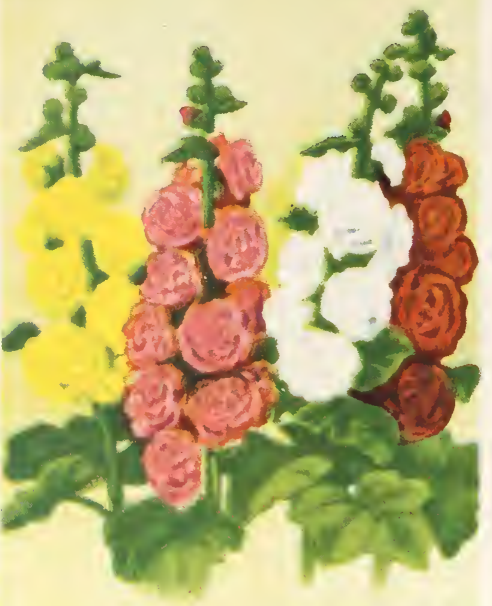

Double Hardy.

Lang's Special Mixture. Pkg. 15c COLUMBINE

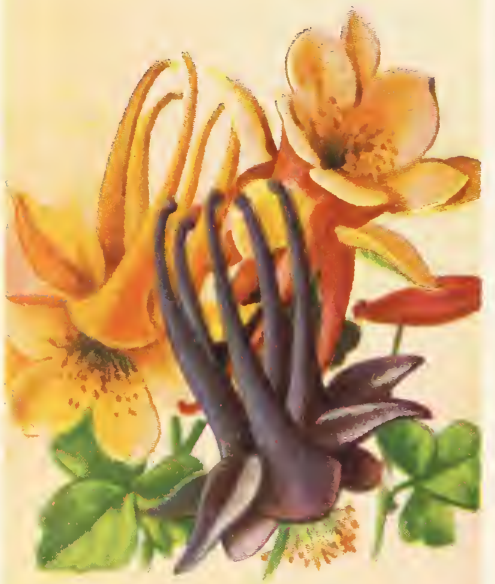

Fancy Double.

Lang's Special Strain. Pkg. 15c PHLOX

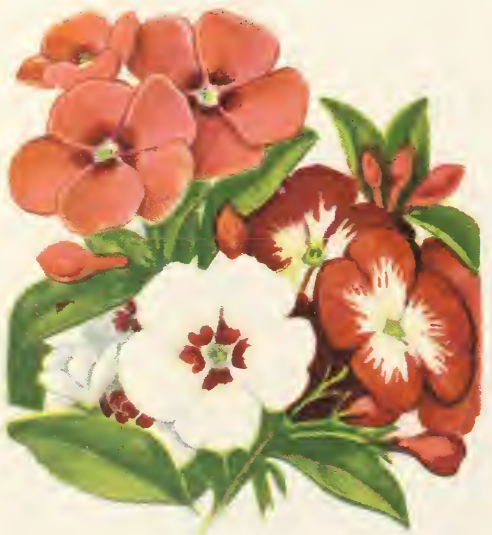

Single Giant. Lang's Best Bedder. Plor.
DAISY

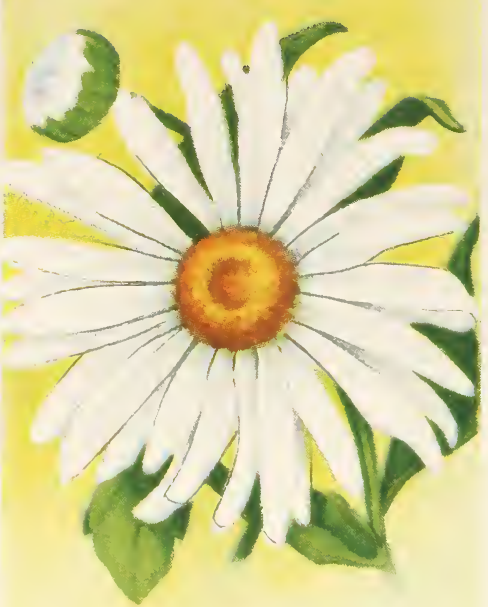

Improved Shasta.

Lang's Long Stem Hardy. Pkg. 25c

\section{POPPY}

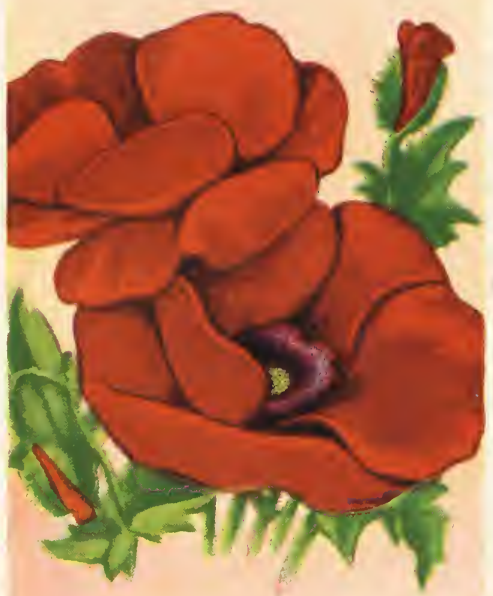

Tulip Flowered.

Lang's Select Strain. Pkg. 15c

BLUEBONNET

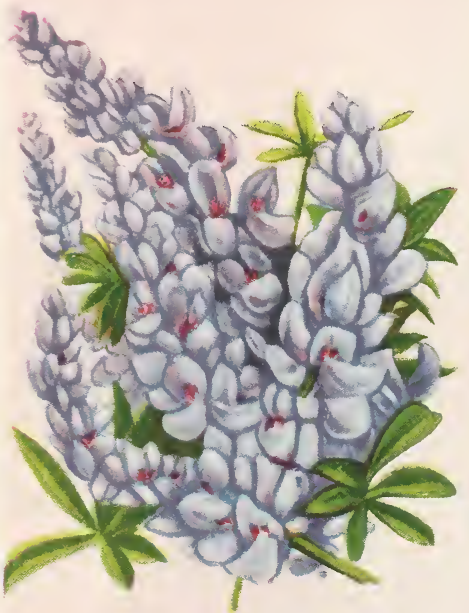

Texas State Flower.

The Admiration of All $\mathrm{Pkg}, 25 \mathrm{c}$
LARKSPUR

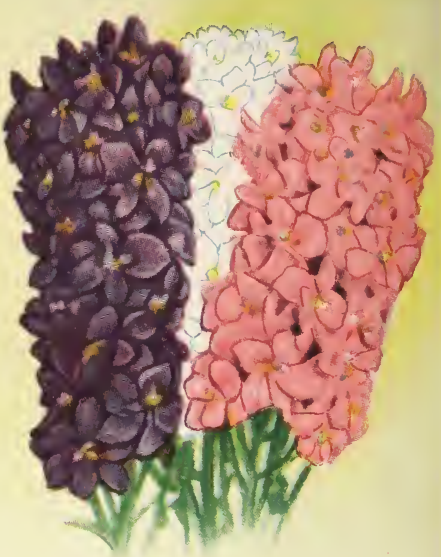

Improved Double.

The People's Favorite. Pkg. 15c

SWEET WILLIAM

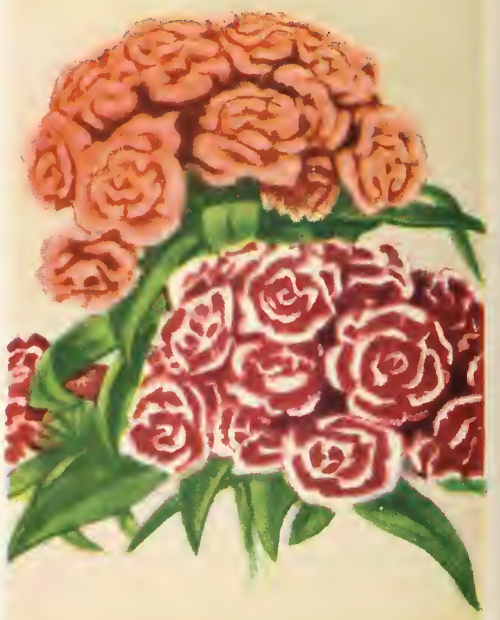

Double Mixed.

Lang's Come Again. Pkg. 15c

SNAPDRAGON

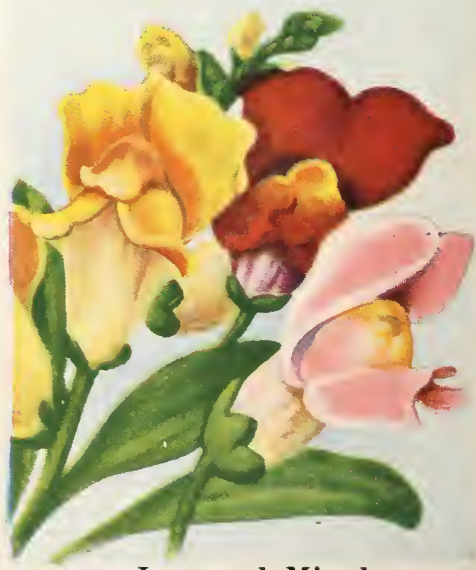

Improved Mixed 


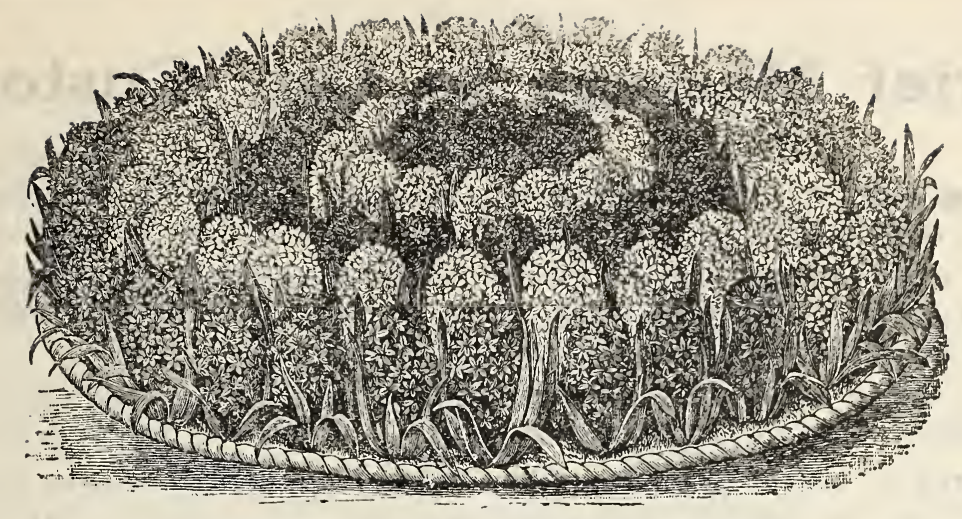

A BED OF DUTCH HYACINTHS IN COLORS

\section{BULBS}

\section{We Specialize on Beautiful Dutch Hyacinths and Darwin Tulips}

\section{Bulbs for Fall and Winter Planting}

SINGLE AND DOUBLE DUTCH HYACINTHS.-This beautiful and flowering bulb comes in the following colors: Red pink, white, yellow, light blue, dark blue. Can be planted in boxes or pots for the home for window blooming or planted in the yard in November. December and January. these bulbs will bloom early in the spring or when soil becomes warm. Fine large bulbs, single or double flowers, $15 \mathrm{c}$ each, $\$ 1.75$ per dozen.

MINIATURE DUTCH HYACINTHS.- While on the order of the Dutch Hyacinth, are of a smaller size with single flowers and come in pink, white and purple. These bulbs are best for yard planting. By planting early and getting a good root system they give excellent flowers. 10c each. $\$ 1.00$ per dozen.

CALLA LILIES.-This Lily is strictly a house plant, the foliage making a decorative plant and as this plant blooms three to five times during the winter it is doubly valuable to the lover of plants and flowers. Large bulbs, 50c; medium size, 35c; small size, 20c each.

EASTER LILIES. - What prettier or purer flower than this beautiful Lily could you find? Large bulbs, 35c each; $\$ 4.00$ per dozen.

YELLOW CALLA LILIES.-Beautiful dark green foliage, some smaller than the Calla Lily with bright yellow spots all over the foliage and a beautiful golden flower. Try at least one for your room. Price 50c each.

PAPER WHITE NARCISSUS.--The Narcissus is grown in soil or in water and pebbles. The flowers are borne in clusters on long stems; very fragrant; first flowering bulb to come in bloom. Can be had for Christmas, and by planting a small lot every two to four weeks until March, flowers can be had all winter and spring in the house at a small expense. Large bulbs, 10c each; $\$ 1.20$ per dozen: $\$ 10.00$ per hundred.

YELLOW NARCISSUS.-A very early flowering Narcissus, same as Paper White Narcissus, but more fragrant and does well planted in soil or in a bowl of water and pebbles. Large bulbs, 20c each; $\$ 2.00$ per dozen.

TRUMPET NARCISSUS EMPEROR.-One of the finest Daffodils in cultivation; entire flowers of the richest yellow, trumpet of immense size and the petals of the perianth are so broad they overlap and measure $3 \frac{11}{2}$ inches across. 15c each; \$1.75 per dozen.

VON SION OR DOUBI.E JONQUIL.-Very large double yellow flowers. For pot or yard planting. 15c each; $\$ 1.75$ per dozen.

FREESIA.-The bulb that everybody wants to grow. There are more flowers on this small bulb than any similar bulb of its size. Flowers creamy white and very fragrant. $5 \mathrm{c}$ each; 50c per dozen.

OXALIS, LARGE BUTTERCUP.-This is the large yellow Oxalis used for pot plants, hanging baskets and boxes. 5c each; 50c per dozen.

OXALIS, MIXED.-Red, white and lavender. 4c each; 35c per dozen.

\section{Darwin Tulips}

We have the best varieties adapted to this part of the country and specialize in the varieties with the largest flowers, best and strongest stems, the clearest and most popular colors, which we grow in countless thousands of the following:

BARONNE DE LA TONNAYE: Deep Rosy Carmine.

CITY OF HARLEM- Brilliant Scarlet.

CLARA BUTT: Delicate Salmon Rose.

FAIRCOMBE SANDERS: Very Large Fine Red. PRIDE OF HARLEM: Brilliant Rosy Carmine. PSYCHE : Light Rose.

REV. EUBANK : Lavender Violet.

INGLESCOMBE YELLOW: Best Yellow.

Many other varieties; all largest bulbs and first grade, 7c each; 75c per dozen; $\$ 5.00$ per hundred.

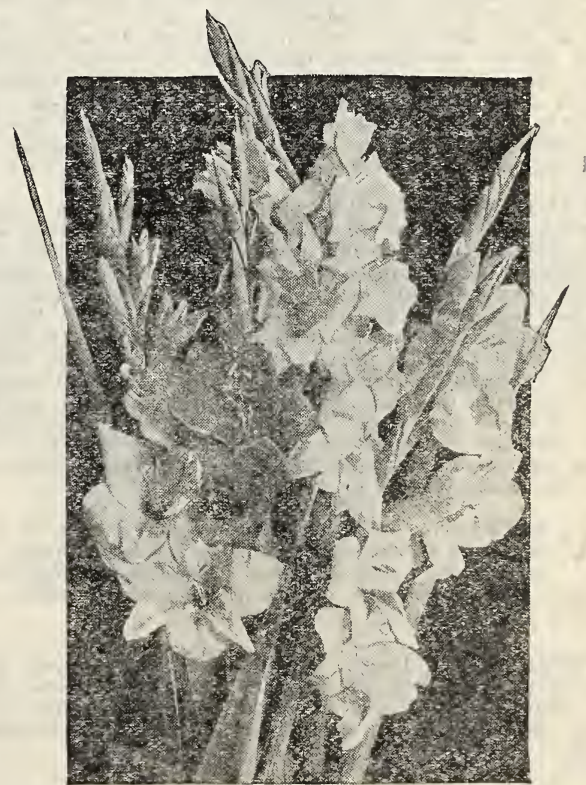

GLAdiolus (Page 3) 


\section{A Brief Message to Our Customers}

We thank you for your business of the past. Some of you have been with us for thirty years, and there is a reason for our long and successful business career.

We have over 100 acres in Nurseries, where we grow more than a million and a half of flowering shrubs, roses, trees, vines, berries, and in fact everything needed to make a home pleasant, profitable and home-like.

We have eighty-seven Greenhouses, 375,000 square feet of glass, to grow an additional million and more of plants, bulbs and flowers for the home and yard.

Four Stores to serve our many thousands of customers, where we carry everything in the seed line, poultry and pet stock, gold fish, canary birds, remedies for pet stock and spray material against insects on your plants, trees, shrubs and flowers. Store where we display the finest cut flowers used for gifts, birthdays, weddings, sick-rooms and floral work for funerals.

When in doubt or cannot find it listed write us; we will deem it a pleasure to help you.

\section{Information for Planters}

\begin{abstract}
DREPARATION of the Soil: The $\operatorname{sos}^{-1}$. for all fruit, shade trees, roses, vines, hedges and evergreens should be prepared as carefully as that required for a crop of wheat, corn or potatoes. The land should be sufficiently drained to relieve the roots from standing in water and should be a deep bed of rich, mellow soil.
\end{abstract}

DREPARATION of Trees or Other Stock in Shipping : Great care is used in digging and packing our shrubbery with the result that only a few of the smaller roots are lost. If any of the roots are broken they should be pruned. Cut back the tops to the extent of about one-half the previous season's growth, taking care to prune in such a manner as will develop a well formed head, to admit air and light freely. Evergreens, the beauty of which depends on their natural form, should be pruned very little. Great pains should be taken in planting and caring for stock. If not ready to plant when the stock arrives, "heel it in" by placing the roots in a trench and covering them with mellow earth, well packed. Water frequently.

DLANTING: Make the holes large enough to admit the roots without any cramping or bending, and deep enough to set the tree to its proper depth. The fine surface soil should be used in covering the roots, and this should be carefully worked among them. Pour in some water when the hole is partially filled. See that the ground is firmly and solidly packed over all parts of the roots by exerting the full weight of the planter upon it, so that there will be no opportunity in planting nursery stock. Fill holes full enough to be even with the surrounding surface after the earth settles. Remove the label. If left on, the wire often cuts into and destroys the tree or branch. When planting dwarf trees, set them low enough to cover the stock upon which they are budded three or four inches.

T ATERING: All newly planted nursery stock is greatly benefited by frequent watering. Roses, Shrubs, Evergreens, Ornamental Trees, Perennials, Bulbs, etc., are exceptionally susceptible to an abundance of water. Best applied in the evening.

D OSES, Privet Hedge, Shrubs, must be severely pruned back. The roots of all stock are given a better opportunity to make a quick start if proper pruning is practiced. Early blooming and beauty of form and foliage will result.

\section{SPACE REQUIRED BY TREES.}

HE SPACE required for different trees varies with the quality of the soil but an estimate is given below. In deep, rich soil, trees and plants would have greater space than in a thinner one. Apple trees should be planted from 30 to 40 feet apart. Peach and Pear trees should be planted from 20 to 30 feet apart. Plum and Apricot trees should be planted from 15 to 20 feet apart. Grape vines and Fig trees should be planted from 8 to 10 feet apart. Berries should be planted from 6 to 8 feet apart.

\section{NUMBER OF TREES PER ACRE.}

$\begin{array}{lr}\text { At } 30 \text { feet apart } & 48 \text { trees } \\ \text { At } 25 \text { feet apart } & 69 \text { trees } \\ \text { At } 20 \text { feet apart } & 108 \text { trees } \\ \text { At } 15 \text { feet apart } & 193 \text { trees } \\ \text { At } 10 \text { feet apart } & 435 \text { trees } \\ \text { At } 8 \text { feet apart } & 680 \text { trees } \\ \text { At } 6 \text { feet apart } & 1200 \text { trees } \\ \text { At } 4 \text { feet apart } & 2722 \text { trees }\end{array}$

\section{OUR TERMS.}

UR TERMS are cash with order. Digging and shipping begins November 15th, and continues until April 1st. Our catalog prices are the lowest we can make and are for stock at yard in Dallas or packed and delivered at express, freight or postoffice.

\section{SHIPPING.}

$\pi$ LL FRUIT and Shade Trees, Roses, Shrubs, Evergreens and Hardy Vines, Heavy and Hardy Bulbs and Roots should be sent by express. Better and moister packages can be sent. Small plants can be sent by mail if so desired, but we strongly advise our customers to have their plants sent by express at their expense, as larger and finer plants can be sent in this way.

Remittance may be made at our risk by bank drafts, postoffice money order, express order or registered letter. Small amounts may be sent by ordinary mail, and postage stamps can always be used to advantage (one and two-cent denominations preferred). 


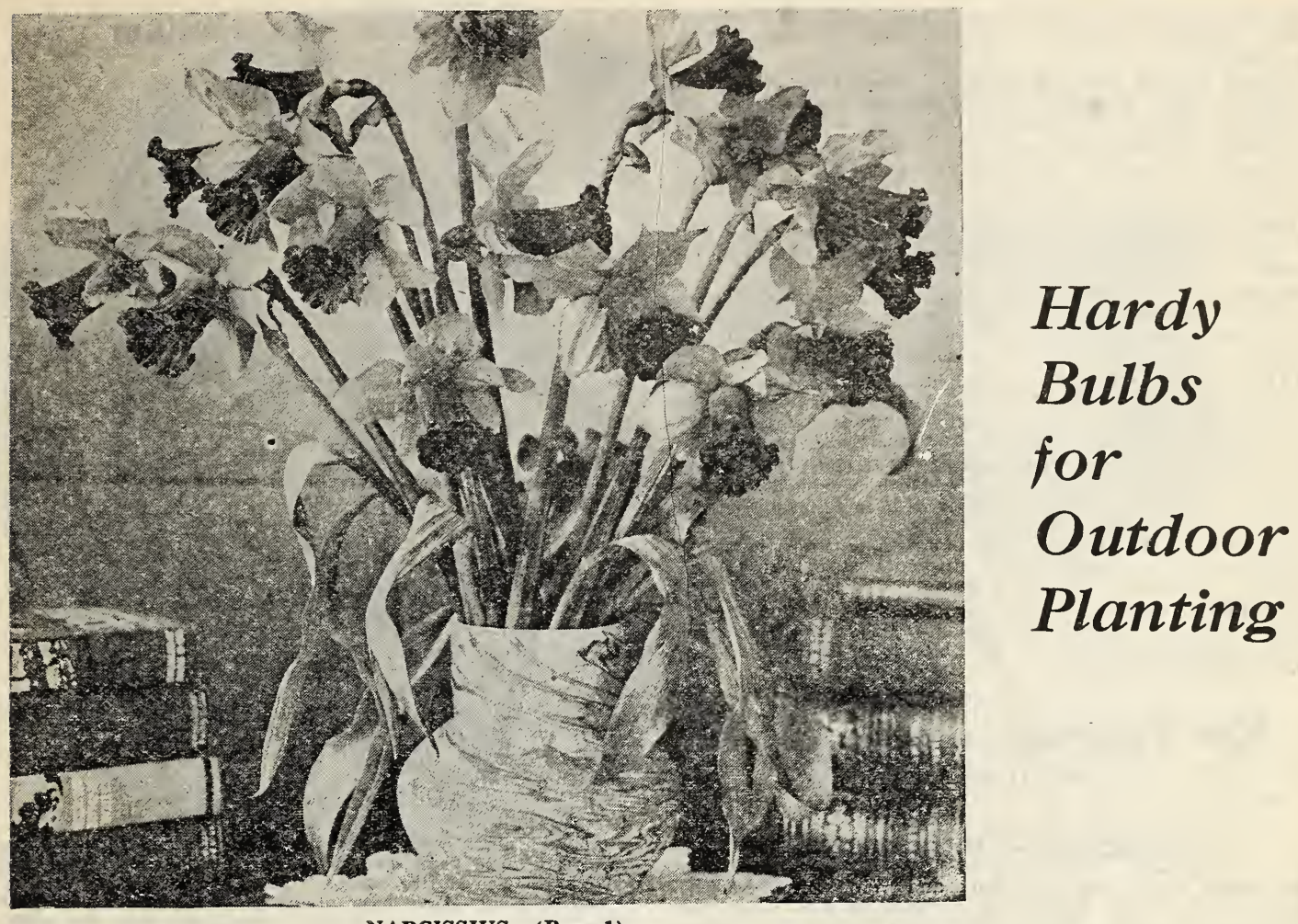

NARCISSIUS (Page 1)

\section{Gladioli}

This beautiful flower has come to the front to stay; it is not only used in yards by the thousands, but it is grown by florists in greenhouses by the millions and the demand for the beautiful flowers is increasing with every year. Finest mixed, 7c each: 75c per dozen.

Following named varieties, strictly No. 1 bulbs; 10c each; $\$ 1.00$ per dozen.

AMERICA.-A beautiful lavender-pink. The flowers are of largest size and are borne on strong spikes.

HALLY.-This is one of the earliest of all Gladioli to come into bloom. The color is a delicate rose with a white blotch.

MRS. FRANCIS KING.-Large blooms of a pleasing light scarlet. It is a strong grower and blooms profusely.

MRS. FRANK PENDLETON, JR. - Large, well-expanded flowers of a lovely salmon-pink, having blood-red blotches in the throat.

SCHWABEN.-Flowers of a delicate pale yellow with a dark blotch in the center. It is a magnificent grower.

CHICAGO WHITE.-Lavender markings in throat. Highly recommended.

\section{Dahlias}

One of the best summer and autumn flowering plants, and now enjoying a wide popularity. Small roots, $25 \mathrm{c}$ each: medium roots, $35 \mathrm{c}$ each; your choice of the following named varieties :

CHAS. LANIER. - Rich dark red: large.

BERLE VON HOLLAND. - Silvery pink.

MINA BURGLE.- Rich luminous dark scarlet.

YELLOW DUKE.--Large soft yellow.

AD LIVONIA.-Large white.

\section{Cannas}

The most desirable bedding plant for the American garden. Give rich soil and abundance of water when the plants are in full bloom. Fine roots ready December 1st to May 1st. If wanted by mail add $15 \mathrm{c}$ per dozen.

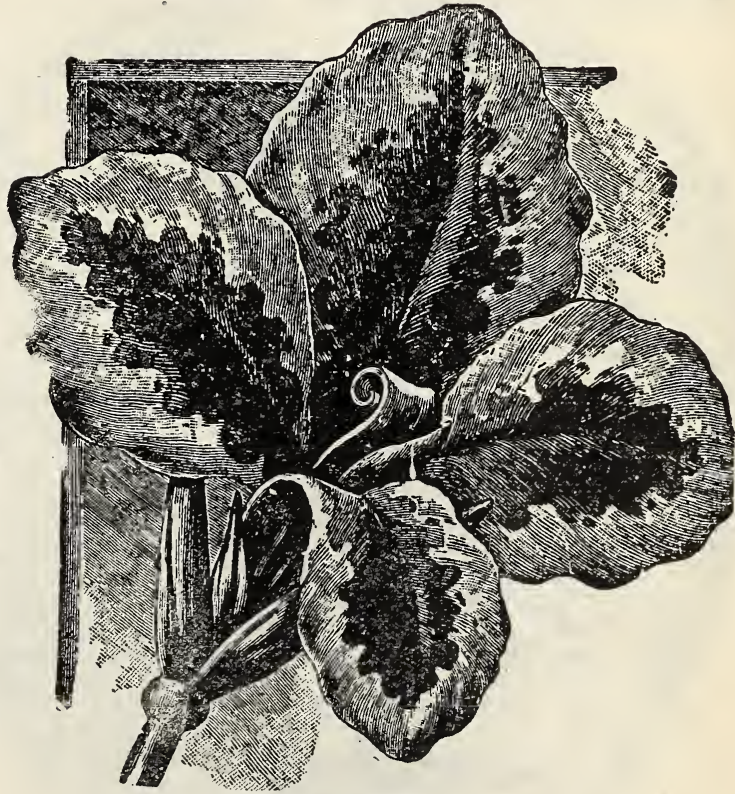

CANNE ITALIA

ROSEA GIGANTEA.-Extra large flowers, borne in such abundance that the mass of color on each plant is truly amazing: a deep. rich rose, almost a coral-carmine; 4 to 5 feet. 20c each; $\$ 2.00$ per dozen.

MRS. ALFRED F. CONRAD. -4 feet. Exquisite salmonpink flowers of the largest size, produced in fine erect spikes well above the green foliage. 20c each: $\$ 2.00$ per dozen.

EUREKA.-The best white for all purposes to which Cannas are devoted. It is of robust constitution. growing four feet 
high, forming sturdy, shapely plants very quickly. A creamy white, changing in full sun to a pure white. 35c each; $\$ 3.50$ per dozen.

CITY OF PORTLAND.--A wonderful bright rosy-pink, much deeper in color than Mrs. Alfred Conrad or Hungaria; a free-flowering, vigorous grower. 25c each; $\$ 2.50$ per dozen. GOLDEN EAGLE.-A wonderful clear golden-yellow of free upright growth. The flowers are produced in large clusters well above the foliage. Four feet. 35c each; $\$ 3.50$ per dozen.

ALPHONSE BOUVIER.-Bright crimson, flower spikes two or three to a stalk: very large and full, all blooming together. $10 \mathrm{c}$ each; $\$ 1.00$ per dozen.

FLORENCE VAUGHAN. - The finest yellow spotted Canna. Flowers very large, brilliant yellow, spotted with bright red : a strong grower and free bloomer. 10c each; $\$ 1.00$ per dozen.

ITALIA-(Orchid Flowered).-Bright orange-scarlet, with a very broad golden-yellow border. The flowers, which are produced on massive stems, about 16 inches long, are set well above large, heavy foliage. 10c each; $\$ 1.00$ per dozen. THE KING OF ALL CANNAS-KING HUMBERT.-Four to five feet. (New Italian Orchid-Flowering). Bronze foliage. In this grand Canna we have a combination of the highest type of flower with the finest bronze foliage. Its flowers are of a brilliant orange scarlet, with bright red markings. It is without doubt unsurpassed in the Canna family. 15c each; $\$ 1.50$ per dozen.

THE PRESDENT.-The greatest red Canna, possessing every desirable quality. Of immense size, unsurpassed in vigor, penetrating color, a free bloomer. Four feet. 20c each: $\$ 2.00$ per dozen.

\section{New Tuberoses-Double Pearl}

$10 \mathrm{c}$ each; $\$ 1.00$ per dozen.

\section{Crinums-Fimbriatum}

Also called Angel Lily and Milk and Wine Lily. In this the flower is a pure white with a streak of pink down the center of each petal. It is delightfully fragrant and blooms all summer. Large bulbs, 35c each.

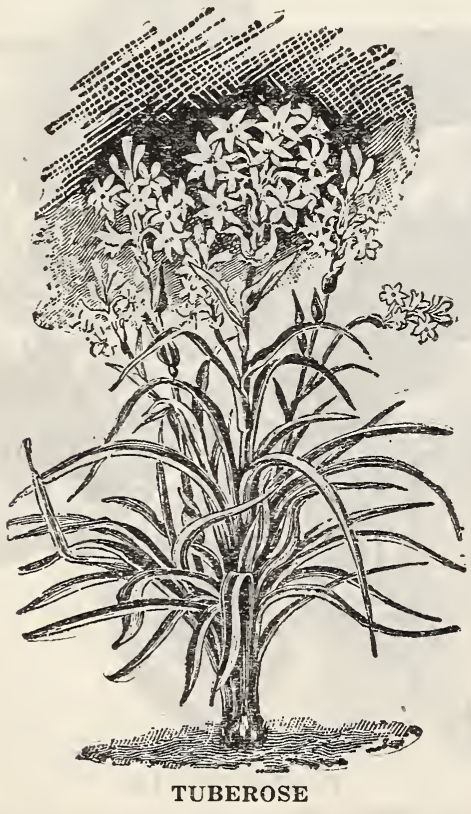

\section{Tuberose, Mexican}

This is something new and very fine; blooms the whole summer and is very fragrant; get at least a few for trial. $10 \mathrm{c}$ each; $\$ 1.00$ per dozen. Plant from November 15th to April 1st.

\section{Caladiums-Esculentum}

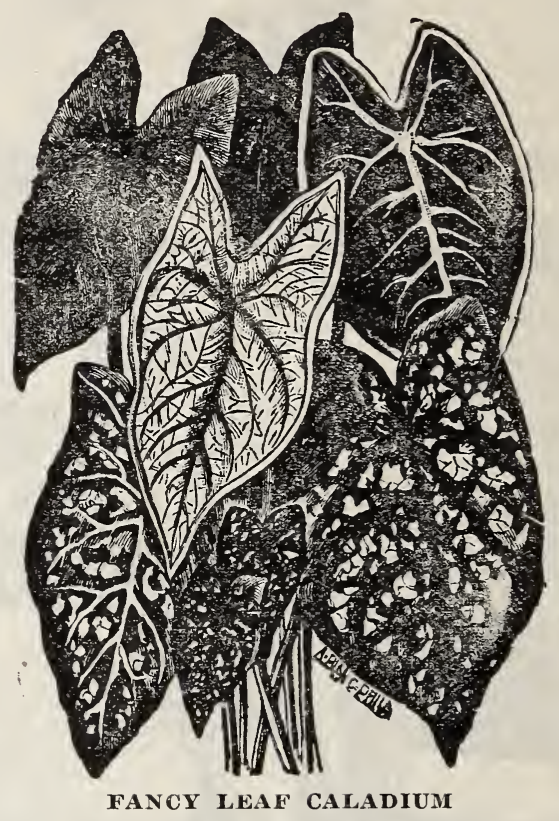

A tropical plant with luxuriant green foliage. The leaves are often more than two feet across and are bright and ornamental the entire season. Will grow in an ordinary garden soil, but should have plenty of water in order to give best results. 15c, 25c. Large bulbs, 35c and 50c each.

CALADIUMS (FANCY LEAVED CALADIUM)-Dry bulbs in February and March. 50c each. Plants in April and May. $\$ 1.00$ and $\$ 1.50$ each.

\section{Lilium Tigrinum}

(Tiger Lily)

Of stately habit, growing from four to six feet high, bearing an immense number of double, bright orange-red flowers spotted with black. $30 \mathrm{c}$ each; three for $85 \mathrm{c}$.

\section{Amaryllis-Amaryllis Johnsonii}

The only red Lily grown that is any good; fine bulbs of these at $50 \mathrm{c}$ each.

\section{Peonies}

Magnificent hardy plants, almost rivaling the rose in perfume, brilliancy of color and perfection of bloom. They are perfectly hardy. Require little or no care, and produce larer and finer blooms when well established. we double white, rose and crimson. Price, 50c each. Plant from December 1st to March 1st.

\section{Iris}

The Iris or Flag is of easy cultivation. They like the sun and thrive best in a rich loam with plenty of moisture.

GERMAN-(Or often called Flags)-Beautiful large flowers, white, yellow and purple. 25c each; $\$ 2.50$ per dozen.

MEXICAN OR SPANISH.-Smaller flowers but beautiful colors and shapes. In beautiful shades of bronze yellow, blue and white. 10c each; 75c per dozen.

JAPANESE IRIS.-Fancy designs. A rival to an orchid. All colors imaginable. Fine bulbs, 35 c. 


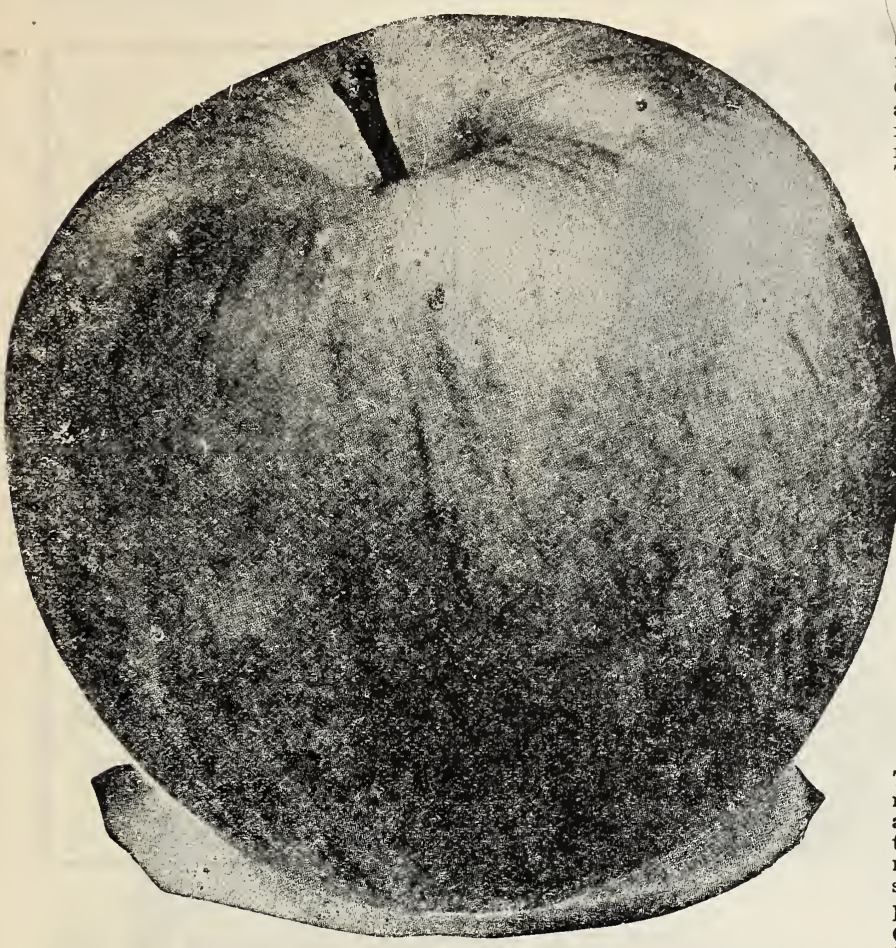

etter in Grayson County, Texas, where it origirated, than any other variety. $\$ 1.00$ each.

COMPASS CHERRY.-A cross between a plum ant a cherry, very productive. The most popular fruit of its kind today wherever known. Do not fail to plant at least one. You will never regret. $75 \mathrm{c}$ and $\$ 1.00$

\section{Fruit Department}

\section{Apples}

We carry a limited quantity of Apples in the very best varieties, select stock. If you live where apples thrive we can please you with our stock and prices. Winesap, Jonathan, Grimes Golden, Red June, Ben Davis, Delicious, Early Harvest. Extra size, 6 to $8 \mathrm{ft}$., $\$ 1.00$; to $6 \mathrm{ft}$. $75 \mathrm{c} . ; 3$ to 4 ft. 50c.

\section{Apricots}

The varieties here listed have proven hardy and prolific bearers. The trees should be handled as the peach, and are profitable both as a market fruit and for home consumption. In planting an orchard do not overlook planting a few apricots. Apricots ripen through June and July. Prices, 3 ft. $75 \mathrm{c}$ : 5 to $7 \mathrm{ft}$., $\$ 1.00$.

CLUSTER.-This valuable variety is claimed to have never missed bearing a season since its introduction. Originated in Texas from seed of Russian Apricot.

EARLY MAY.-Yellow, freestone, rich, juicy: of Russian strain. Very early, often ripening the last of May.

\section{Cherries}

Only a few varieties of Cherries have been found valuable in the South. These trees appear to do best in dry yards, or other uncultivated grounds.

EARLY RICHMOND.-Early, dark red, sub-acid ; most prolific and hardy of all varieties tested here. $\$ 1.00$ each.

NEW CENTURY.-This new Cherry seems to be a cross between Morella and the sweet type of Cherries; early, large, light red, with good flavor. It is a strong grower, with healthy, vigorous foliage, and for a number of years has borne

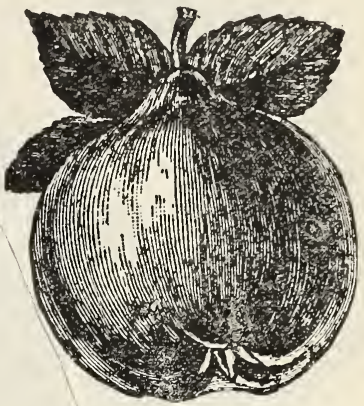

\section{Crab Apples}

4 to 5 feet Each $\$ 1.00$; Dozen $\$ 10.00$ 3 to 4 feet ….... Each 75c; Dozen $\mathbf{7 . 5 0}$

TRANSCENDENT ClAB.-Tree strong grower, making a large and bequtiful tree. An early and abundant bearer. Perhap the most valuable of this class Fruit large, lould, yellow, shaded with red. Valuable for presprving and cookins wu said to be one of the best for cider. September. RED SIBERIAN.-One of the largest crab apples. Grows in clusters; yellow vith dark scarlet cheek. Bears young and abundanty. September.

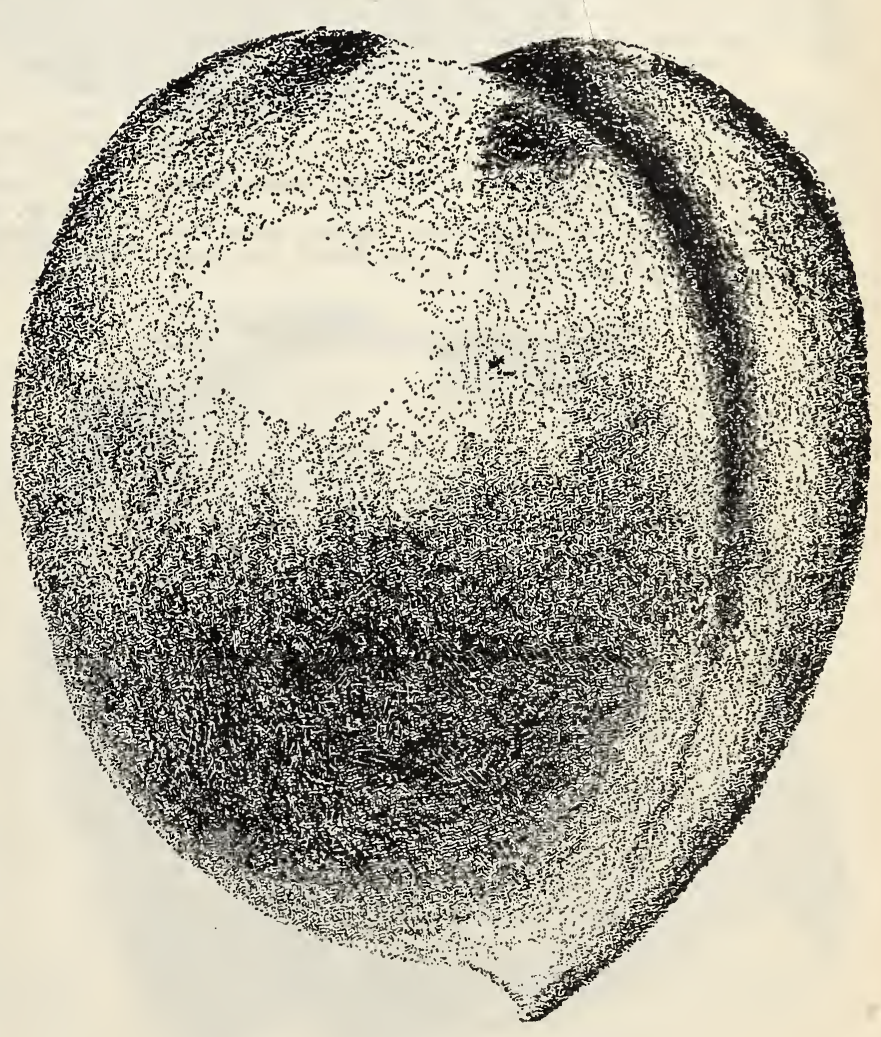

ELBERTA PEACH 


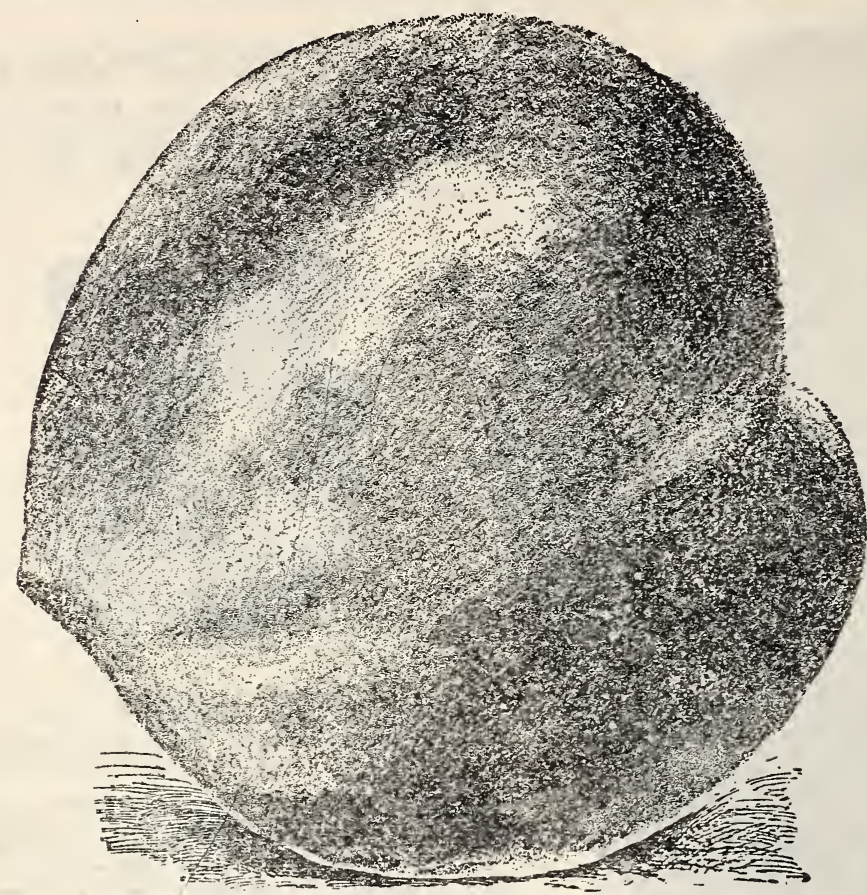

\begin{tabular}{|c|}
\hline \$1.50 \\
Surprise Collection \\
of Evergreens \\
All labeled \\
We have a surprise \\
collection of 6 beau- \\
tiful ever greens: \\
Italian Cypress, Ari- \\
zona Cypress, Arbor- \\
vitae, Ligustrum, \\
Euonymus, Amu- \\
rense. Don't fail to \\
include one collection \\
in your order. Six \\
for \$1.50, parcel post \\
prepaid. \\
\hline
\end{tabular}

MAMIE ROSS

\section{Peaches}

Peaches are among the most desirable fruits, and the peaches of Texas are famous. Many new, rare and prolific varieties are discovered every year. All classes and varieties are adapted to most parts of Texas. Early varieties ripen in May and June, while others ripen continuously until October.

$\begin{array}{lrr}\text { Extra large, 2-year, } 6 \text { to } 8 \mathrm{ft} ., \text { select } & \text { Each } & \text { Dozen } \\ & \$ 1.00 & \$ 10.00\end{array}$ First grade, 5 to 6 feet, strong $\quad .50 \quad 5.00$ 3 to 4 feet, good freestone. July ist to 15 th.

CARMEN PEACH.-Nationally known variety, white flesh, very sure anc prolific, in appearance like Mamie Ross, ripening middle to latter part of June. Free.
CHINESE CLING.-Very large, red cheek, white flesh, juicy. Ripe July 25th.

EARLY WHEELER.-The largest and most attractive of the early varieties. Strong grower. Fruit white with red blush. A good shipper and fine commercial variety. Ripens in early June. Cling.

ELBERTA.-Very large, rich yellow with red cheeks; meat yellow; good shipper; splendid for preserving; freestone. July.

GOVERNOR HOGG - A large white clingstone: Texas introduction. A very valuable peach for family use. Ripe July 20 th to 25 th.

INDIAN BLOOD.-It is the large, blood red, juicy cling stone peach we used to know when we were boys. Everybody that ever knew it wants a few trees, and so we are glad to be able to offer such a general favorite once more.

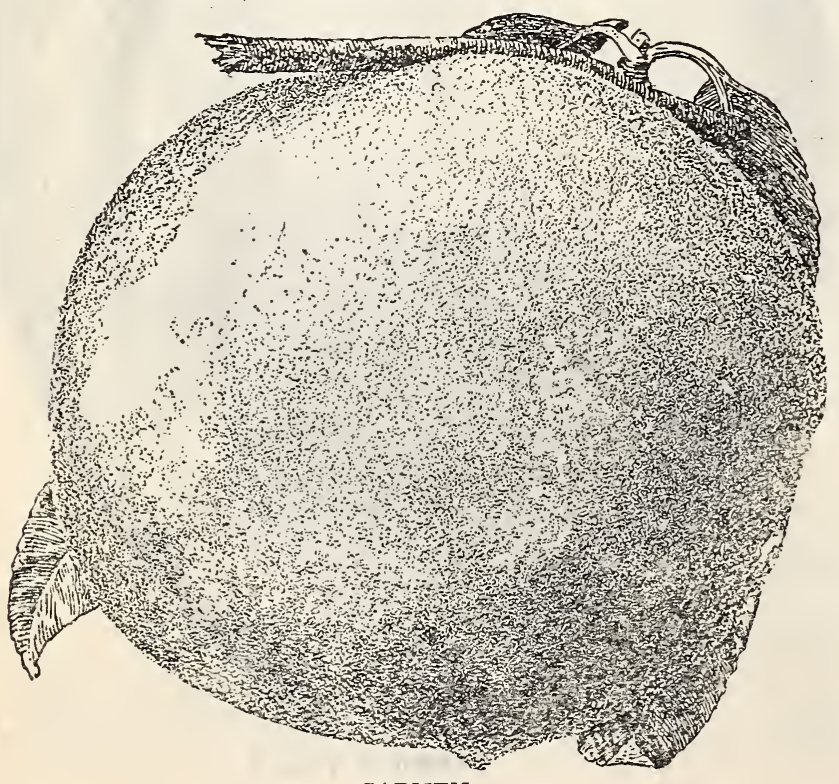

CARMEN
LATE ELBERTA.-A fine peach of Elberta type; perhaps a month later.

MAMIE ROSS.-Large, white, almost covered with carmine; flesh white, juicy and of good quality. One of the best for family use and probably the best early commercial variety; semi-cling. Ripe in June.

MAYFLOWER-(Semi-Cling).-The earliest, about June 20th, red all over, firm, of good size and shape, good quality for an early peach; hardy; productive, bears young.

OLD MIXON CLING.-Large, round, red cheek, sweet, firm; valuable. Ripe July 20.

STINSON'S OCTOBER. - Medium, white with red cheek, and of excellent flavor. A profitable peach for late market. Cling. 


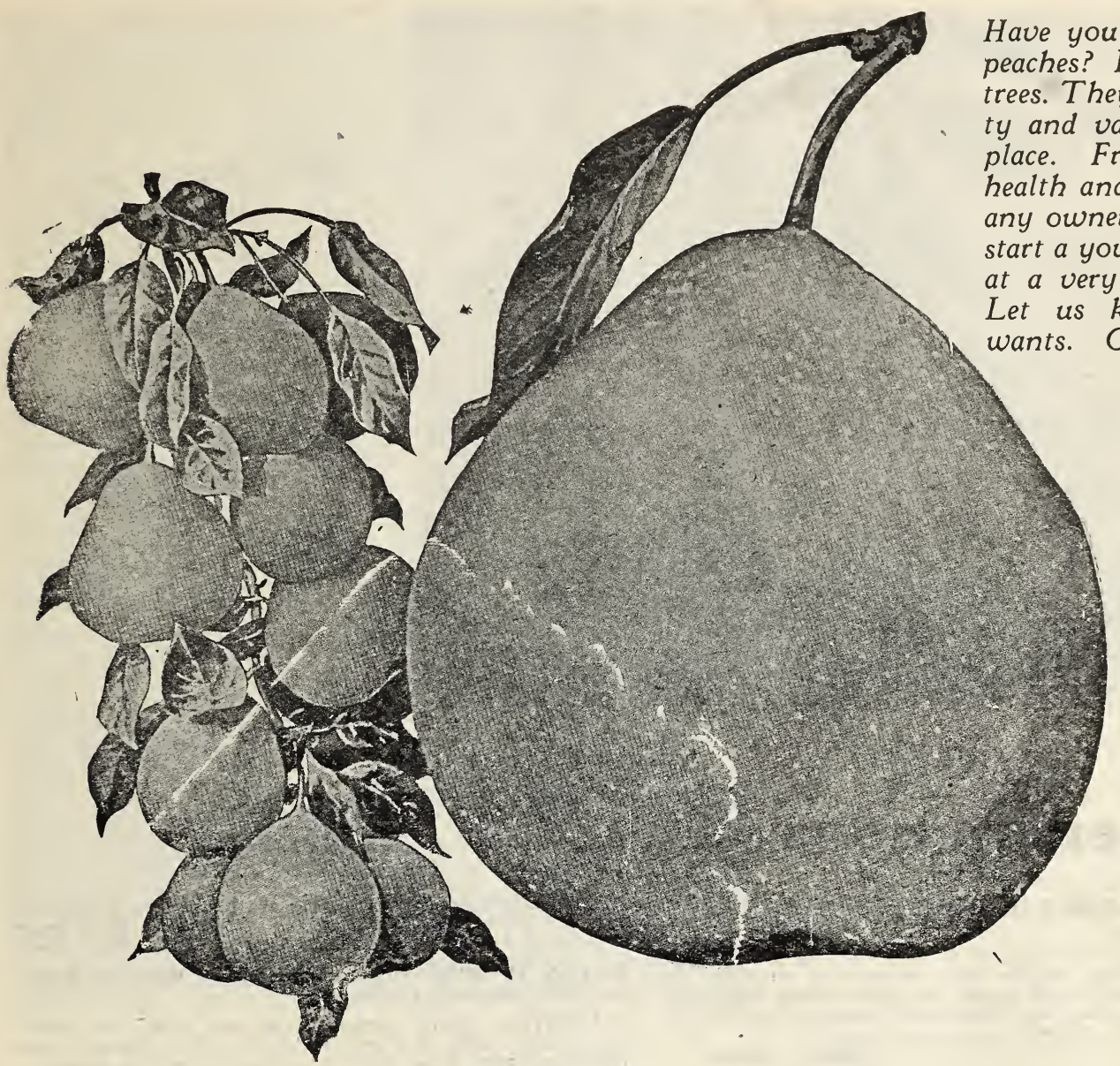

GARBER PEAR

\section{Pears}

Our Pears are grown on Imported French stock. Our trees are healthy and free from disease.

This fruit is growing in popularity since many new, hardy and prolific varieties are being introduced. In habit of growth and requirements the pear is similar to the apple. The trees require a rich soil, underlaid with deep, moist clay. The fruit should be gathered before it is fully ripe and stored in a cool, dark place to ripen properly.

$\begin{array}{lrr}\text { First grade, 2-year, } 6 \text { to } 7 \text { feet } & \text { Each } & \text { Dozen } \\ 5 \text { to } 6 \text { feet. } & \$ 1.00 & \$ 10.00 \\ 3 \text { to } 4 \text { feet } & \mathbf{7 5} & \mathbf{7 . 5 0} \\ \end{array}$

GARBER-(Oriental Hybrid).-Large, of good quality; very vigorous, hardy and prolific; is growing very popular.

KIEFFER.-Large, yellow, red cheek, oval; flesh white and juicy; valuable for preserves; also for eating when ripening in boxes; tree large, productive and hardy. Most valuable of all pears for Southwest.

SECKEL.-Tree a moderate grower and less subject to blight than most varieties. Fruit small, rich, yellowish-brown and red; rich, fine flavored. August.

\section{Plums}

This is the most universal, most easily grown and most useful of all our fruits. The trees are hardy, vigorous and prolific. Some of the late blooming varieties never fail to bear in a location adapted to their growth.

SEASON OF RIPENING.-Varieties in the following list will supply best fruit in about the order named. This list will extend from May to September.

First grade, 2-year, 5 to 6 feet

Each Dozen

First grade, 2-year, 4 to 5 feet $\$ 1.00 \$ 10.00$ Smaller size, 35c and 50c.

AMERICA.-Tree very thrifty and symmetrical. Fruit medium to large, yellow with pink cheek. Considered one of Burbank's best productions. A good bearer. July.

BURBANK-(Japan).-Large, round, dull red: has firm, sweet, yellow flesh; ripe in July. A reclining grower; hardy and very prolific. One of the most popular of commercial plums.

GOLDEN BEAUTY.-Of medium size, yellow, acid; hardy, very productive. Late.

GONZALES.-Said to be a cross between a native plum and a Japan plum. Large, bright red, of delicious flavor; vigorous, hardy, productive.

SHIRO.-A very desirable large to very large, clear, yellow plum, oblong and of unsurpassed quality, ripening latter part of June.

SIX WEEKS.-One of the best productive plums grown; ripens very early, of fine flavor, red in color: good to eat fresh and fine for cooking or preserving; best all-around plum for the South.

WICKSON-(Japan). - Very large, oblong-pointed, yellow, changing to brownish-red; an upright grower; bears young; very valuable. July.

WILD GOOSE.-Large, red, oblong; good Chickasaw; ripe in June. 


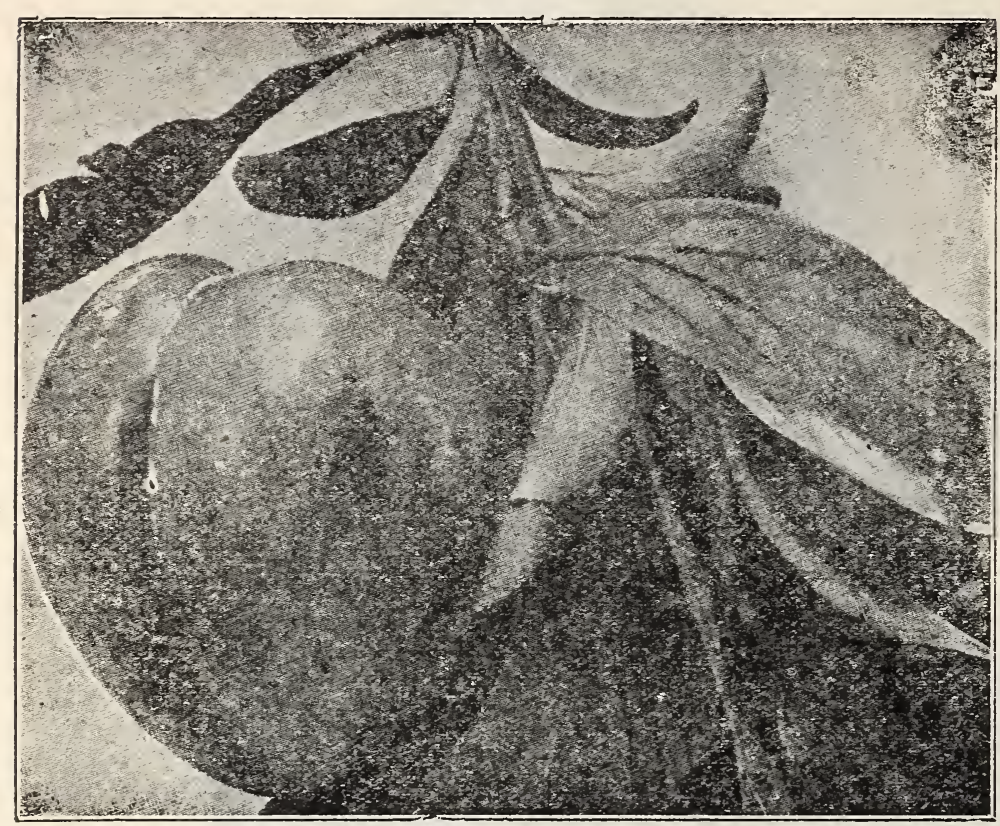

BURBANK PLUN
Plums good to preserve make fine jelly. Still better to eat fresh from the tree. Think what a delicious fruit these large Japanese varieties would be. Plant this fall. Plant all trees, roses and shrubs December to February.

\section{Persimmons}

\section{Japan Persimmons}

This royal fruit from Japan is deservedly popular, most beautiful in foliage and the most delicious of all fruit. It gains in the estimation of people everywhere when they learn its value. We offer best obtainable varieties, grafted on native stocks, as follows :

$\begin{array}{rrr}3 \text { to } 4 \text { feet } & \text { Each } & \text { Dozen } \\ 4 \text { to } 5 \text { feet } & 1.00 & \$ 10.00 \\ & 1.50 & 15.00\end{array}$

KURO KUME.-Large, round, dark red skin and flesh; delicious when packed away to ripen; productive. Ripe in October.

HAKUME.-Large, round, yellow, flesh red, good keeper; fine when soft.

\section{Nut Trees}

\section{Pecans}

Every yard or home should have one or more Pecan Trees. Grafted Pecan Trees give most reliably good results.

Wonderful progress is being made in the improvement or selection of Pecans. Fine qualities once secured are maintained with absolute certainty by grafting or budding from these fine trees on seedling stocks. Orchards thus selected and started are an unfailing source of greatest profit and gratification. We have a good stock of the following finest varieties: Stewart, Frotcher, Van Deman, Success. Prices of budded and grafted Pecans:

\section{Figs}

A few hardy varieties of the Fig are planted to profit here. Prices, Fig Trees: 2 to 3 feet.

Each Dozen $\$ 0.50 \$ 5.00$

BROWN TURKEY.-Oblong; dark brown with blue bloom red flesh; delicious; prolific.

CELESTIAL.-Hardy farther north than most other varieties. Fruit small, of a pale violet color, fine flavored, early ripening, about June, and continuing for several months.

MAGNOLIA.-Most popular Fig in the coast country.

\section{Grapes}

\section{Standard Grapes}

We are able to give our customers from our rich limestone soil a root system that is bound to please.

Prices except where noted:

No. 1, strong 2-year plants

Each Dozen

No. 1, light grade, but good

$\$ 0.50 \$ \$ 5.00$
ductive, free from mildew and leaf worm. One of the most satisfactory and popular sorts. August.

CATAWBA.-Red; table and wine.

CONCORD.-Large; blue-black; standard commercial sort. North.

DELAWARE.-Small, red, tender, very sweet and delicious : hardy and productive.

HERBEMONT-Berry small, dark blue, tender; bunch large ; vigorous, hardy, productive, extensive and deservedly popular; makes good vines; late, fine arbor grape.

MOORE'S EARLY.-Large, black with blue bloom; valuable for earliness.

MOORE'S DIAMOND.-Finest white. A flne arbor grape. R. W. MUNSON.-Black, vigorous grower, medium to large clusters, skin never cracks; juicy and tender. Fine quality. July.

NIAGARA.-A fine large white-green grape; good bearer and fine table grape. 


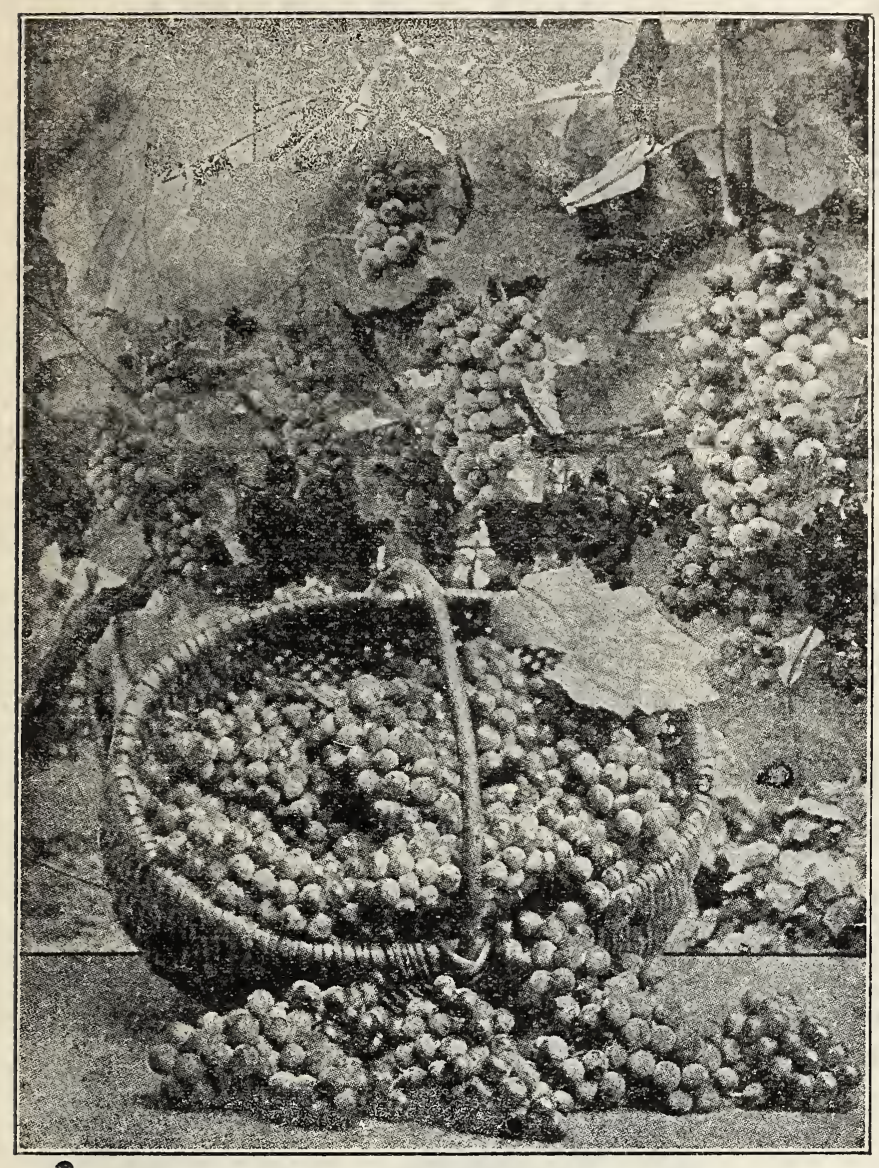

CATAWBA GRAPE

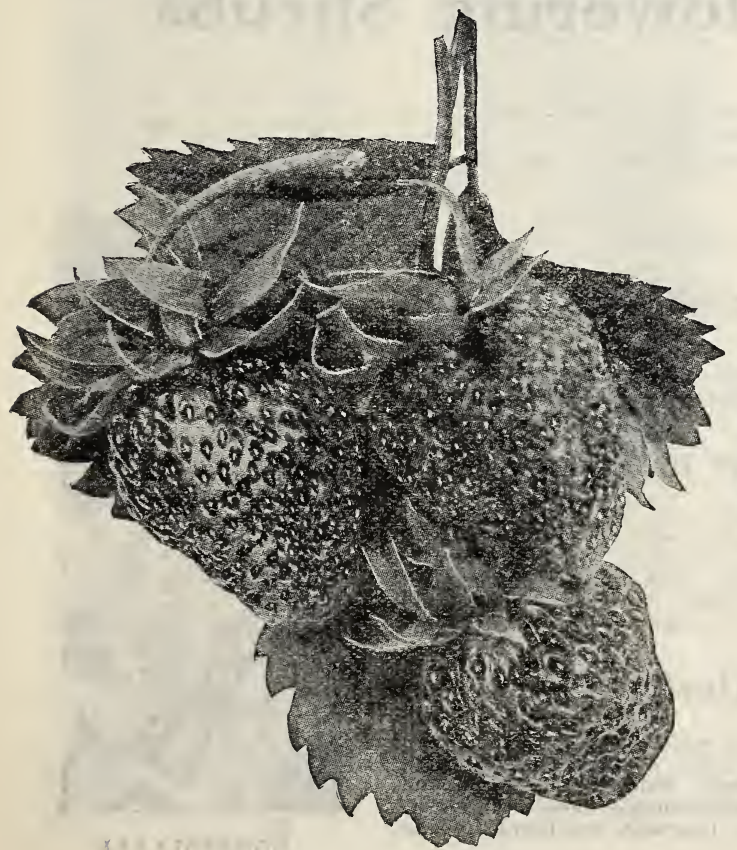

KLONDIKE STRAWBERRIES

\section{Berries}

\section{Blackberries and Dewberries}

The blackberry, like the grape and plum, is native to the soil and will grow anywhere It is one of the most reliable, wholesome and valuable of all fruits. By planting early and late varieties, a continuous supply can be enjoyed six or eight weeks each season. You will notice we do not quote berries in lots of less than twenty-five plants in a variety. They are tied in bunches of twenty-five in the fields and cannot be broken. Any purchaser needs as many as twenty-five of a variety.

Austin, Dallas, McDonald........\$2.00 $\begin{array}{rr}\text { Per } 25 & 100 \\ & \end{array}$ AUSTIN DEWBERRY.-Very large, sub-acid ; hardy, vigorous, very productive. Plant is an erect, strong grower, rather than a trailer.

DALLAS.-Large, round, of good quality ; vigorous, hardy, prolific, extensive. Has proved to be one of the most satisfactory varieties to grow. Native of Dallas, Texas.

McDONALD.-Large, tender, juicy, of best quality. Earliest, hardiest, most vigorous and most productive of all berries here. This is a new berry, a cross between the blackberry and dewberry. It is incomparably more productive than any berry fruited here. Should be planted with other blackberries, as they do not set a full crop of berries by themselves. HIMALAYA BERRY.- It is an exceedingly strong grower and free bearer, especially when planted with McDonald or Dallas. Fruit is of medium size and fine flavored. Strong plants, 25c; $\$ 2.50$ per dozen.

\section{Strawberries}

KLONDIKE.-Large, early, best berry for the South and coast country.

LADY THOMPSON.-Large, good color, uniform, hardy, valuable. Staminate.

$\begin{array}{rrr}\text { Dozen } & 100 & \mathbf{1 , 0 0 0} \\ \text { Price..............\$0.35 } & \$ 2.00 & \$ 15.00\end{array}$

\section{Everbearing Strawberries}

A wonderful berry with all the good qualities and the flavor of a strawberry, but everbearing where moisture is normal. Fine plants, $75 \mathrm{c}$ per dozen; $\$ 5.00$ per 100 .

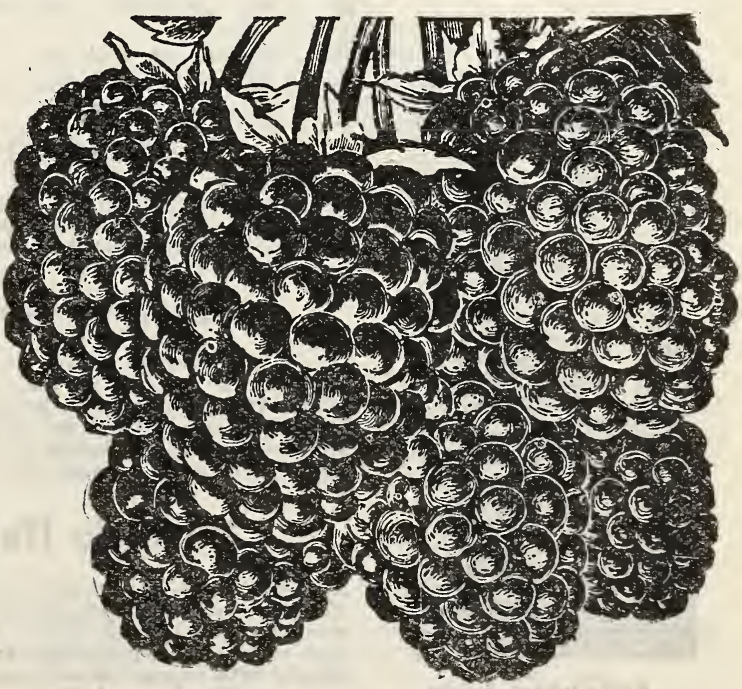

DALLAS BLACKBERRIES 


\section{Shade Trees}

AMERICAN ELM.-The Long Leaf American Elm is perhaps one of the largest growing, giving more spread than any other shade tree grown, outside of the few native trees in other parts of the country; it is of long life and easy culture. 8-10 ft., $\$ 1.50 ; 10-12 \mathrm{ft}$., $\$ 2.50$.

SYCAMORE.-Large, stately, symmetrical, hardy ; long-lived ; has beautiful white branches and large green leaves. One of the best shade trees everywhere. Our stock cannot be excelled. 8-10 ft., $\$ 1.50 ; 10-12 \mathrm{ft}$., $\$ 2.50$.

HACKBERRY.-The tree for the South; long life. 8-10 ft., $\$ 2.00 ; 10-12$ ft., $\$ 3.50$.

CHINESE ELM.-The latest sensation in a shade tree. Requires very little water and care; grows twice as fast as any other tree. No large trees to offer this year. 5 to $6 \mathrm{ft}$., $\$ 1.00 ; 6$ to $7 \mathrm{ft}$., $\$ 1.50 ; 7$ to $8 \mathrm{ft}$., $\$ 2.50 ; 8$ to $10 \mathrm{ft}$., $\$ 3.50$; 10 to $12 \mathrm{ft}$., $\$ 5.00$ and $\$ 7.50 ; 12$ to $14 \mathrm{ft}$., $\$ 10.00$ and $\$ 12.50$ each.

\section{Ornamental Trees}

CHINESE UMBRELLA TREE-(Texas Umbrella).-A rapid grower with luxuriant deep-green foliage, forming a beautiful canopy top, enduring perfectly until severe frost. 6-foot canopy top, endurit.
trees only. $\$ 1.25$.

LOMBARDY POPLAR.-A very pretty upright growing ornamental tree used for ornament and not for shade. 6-8 feet, $\$ 1.00 ; 8-10$ feet, $\$ 1.50 ; 12-14$ feet, $\$ 2.50$ and $\$ 3.00$.

WILLOW-(American Weeping).-A large, rapid grower, of graceful weeping habit, showing greatest beauty in moist location. 6 to 8 feet, $\$ 2.00$ each.

CATALPA BUNGEI.-A beautiful umbrella-topped tree, very distinct and striking as well as hardy. Fine for driveways or specimen plants. We bud on a six to seven-foot stem. 2 -year heads, $\$ 3.00$ each; $\$ 30.00$ per dozen.

TEAS' WEEPING MULBERRY.-A novel, attractive tree, the limbs naturally weeping to the ground. We graft to six and eight-foot stems. This gives a nice height for either single specimens or park rows. 2-year heads, $\$ 3.00$ each; large specimens, $\$ 4.00$ and $\$ 5.00$ each.

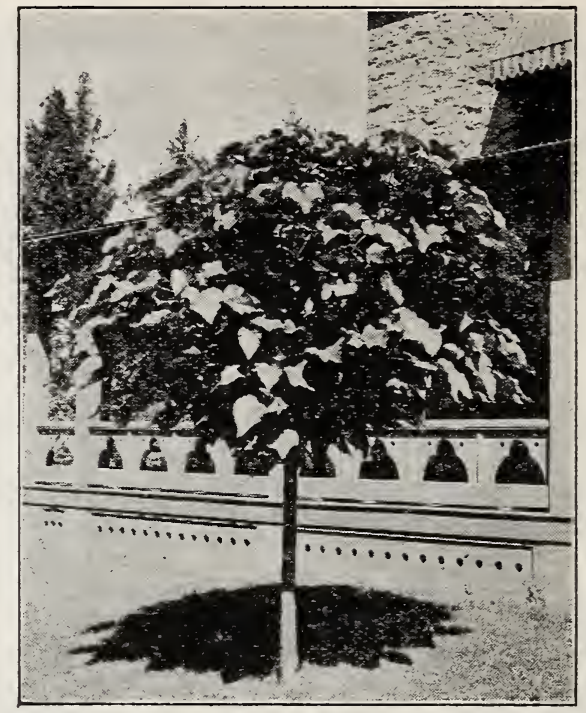

CATALPA BUNGEI

\section{Mulberries}

The Mulberry is a natural growth of the South. It is a beautiful shade tree and furnishes a pleasant fruit for many weeks. Pig and poultry raisers find it a profitable tree. We offer a choice selection of the best varieties.

BLACK ENGLISH.-Very prolific and earlier than the Hicks. 5 to $8 \mathrm{ft}$., $\$ 1.00$ each.

HICKS' EVERBEARING.-Tree large, vigorous, hardy, very productive, bearing large quantities of fruit during eight or ten weeks. $\$ 1.00$ each.

\section{Lang's Quality Flowering Shrubs}

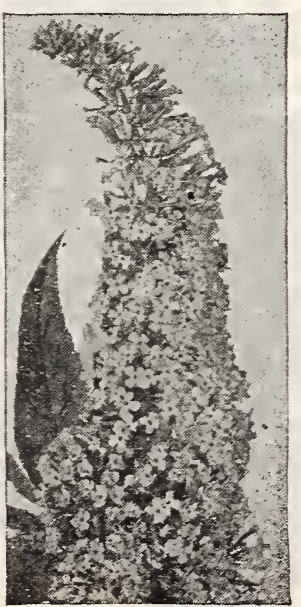

BUTERFLY BUSH
We are grading our Shrubs into No, 1 No, 2 and No, 3 grades. All, however, will bloom the first year.

No. 1 are the largest and strongest plants, some varieties 4 to 6 feet.

No. 2 medium size and full.

No. 3 smaller and lighter. Good stock.

\section{Abelia Grandiflora}

Best evergreen flowering shrub grown of medium height. Thousands of small flowers until frost. $35 \mathrm{c}, 50 \mathrm{c}$ and $75 \mathrm{c}$. Also note on Evergreen and Hedge Page.

\section{Althea or Rose of Sharon}

One of the hardiest shrubs grown, and for single specimens or grouping there is no plant that will give you better results. We grow them in great quantities and can give you plants in assorted colors, white, pink, purple, variegated. We also handle in double or single flowering. The plants bloom from early summer until autumn. 75c, 50c and 35c.

\section{Buddleia Butterfly Bush}

A shrub not so well known but which stands the heat and drought of summer remarkably well. A strong grower, often attaining a height of 6 to 8 feet. Foliage dark green and very heavy. Throughout the entire summer flowers of violetpurple with orange throat, very fragrant, are borne in long plumes. $75 \mathrm{c}, 50 \mathrm{c}$ and $35 \mathrm{c}$.

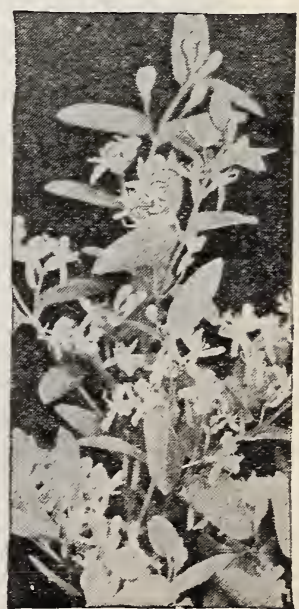

HONEYSUCKLE 


\section{A Real Novelty in Shrubs} New Red-Leaved Japanese Barberry

(Berberis Thunbergi Atropurpurea)

It is only once in a lifetime that a really worth-while outstanding novelty in hardy shrubs is introduced, and in this new Barberry we have such a plant.

It is similar in all respects to the green-leaved Japanese Barberry which is so popular for mixing in the shrubbery border, as single specimens, or for planting in clumps on the lawn, as well as for foundation plantings and for hedges, but the foliage of this new variety is of a rich, lustrous, bronzy red, becoming more brilliant and gorgeous throughout the summer and in the fall changes to vivid orange, scarlet and red shades. In this coloring it is unequalled by any other shrub and is followed by the same brilliant scarlet berries common to the type, which remain on the plant the entire winter. In order to develop its brilliant coloring at all seasons it must be planted in full exposure to the sun.

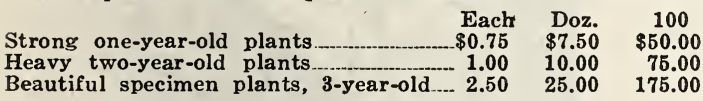

\section{Bush Honeysuckle (Red Tartarian)}

A large growing shrub with upright and spreading branches. Foliage bright green, flowers borne freely during May or June, followed by red berries, which cling to the branches for several weeks. A vigorous grower and of easy cultivation. We can also furnish this shrub in a beautiful shell pink, very fragrant. $75 c, 50 c$ and $35 c$.

\section{Crepe Myrtle}

Few people realize the satisfaction from planting of Crepe Myrtle. When other plants refuse to bloom you can always find the Crepe Myrtle loaded with a mass of flowers. We grow in quantity the pink and crimson. It is especially attractive for hedging or grouping. 50c and $75 \mathrm{c}$.

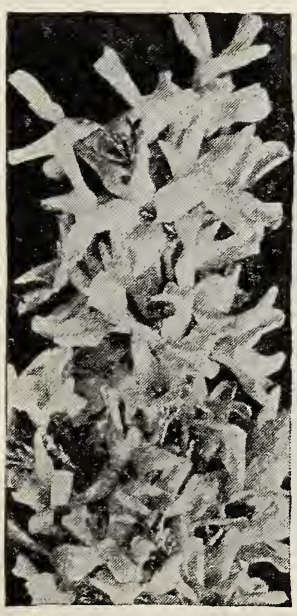

FORSYTHIA

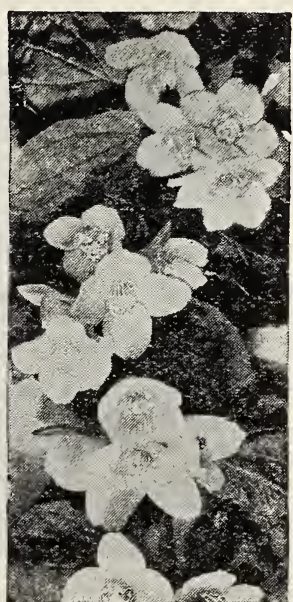

PHILADELPHIUS OR

\section{White Crepe Myrtle}

$75 \mathrm{c}$ and $\$ 1.00$ each.

\section{Vitex or Chaste Tree}

A valuable small tree with sage-like foliage; especially attractive because of its pale lilac flowers, which are produced in long spikes and which last a long time. Will grow where ordinary shrubs fail. 50c, 75e and $\$ 1.00$ each.
Lilac

(Both White and Purple)

An upright, attractive shrub, greatly admired for its profusion of blue and purple fragrant flowers in early spring. $A$ favorite in all sections. $50 \mathrm{c}, 75 \mathrm{c}$ and $\$ 1.00$ each.

\section{Deutzia}

An upright, thrifty shrub with a profusion of delicately beautiful white and pink flowers in spring. $35 \mathrm{c}, 50 \mathrm{c}$ and $75 \mathrm{c}$ each.

\section{Flowering Almond}

Beautiful blooms set upon branches in early spring. White and pink. 50c, 75c and $\$ 1.00$ each.

\section{Peach, Flowering}

A small tree with foliage similar to the peach tree, but the limbs are covered with dainty flowers similar to miniature roses. White and red. 75e and $\$ 1.00$ each.

\section{Willow, Flowering}

One of the most useful of yard shrubs; flowers all summer; grows to a height of 10 feet. $50 \mathrm{c}$ and $75 \mathrm{c}$ each.

\section{Forsythia}

\section{(Golden Bell)}

Highly ornamental early spring flowering shrub. Foliage deep green, flowers appearing before foliage is produced. $35 \mathrm{c}, 50 \mathrm{c}$ and $75 \mathrm{c}$ each.

\section{Hydrangea}

(P. G.)

A hardy shrub, producing immense flower heads of white and rose early in the summer. $50 \mathrm{c}$ and $75 \mathrm{c}$ each.

\section{Lespedeza Bicolor}

Of strong, shrubby growth; very attractive because of its dark reddish-purple flowers. A hardy shrub which will stand the heat and drought of summer. Desirable because of its bright attractive coloring. $50 \mathrm{c}$ and $75 \mathrm{c}$ each.

\section{Mexican Yucca}

A beautiful plant for old-fashioned gardens or shrubbery beds. Hardy and fine grower. Grows in any soil. Strong plants, 50c and $\$ 1.00$.

\section{Philadelphius or Mock Orange}

Upright growing, covered with large white fragrant flowers in spring. 50c and $75 \mathrm{c}$ each.

\section{Poinciana}

\section{(Bird of Paradise)}

This is truly a shrub for the Southwest, for it will thrive in any kind of soil and blooms throughout the entire summer. Foliage finely cut; lace-like; flowers pea-shaped, yellow with long red stamens. 50c, 75c and $\$ 1.00$ each.

\section{Japan Quince}

\section{(Cidonia Japonica)}

A beautiful shrub for early spring blooming. They produce immense clusters and bright red bell-shaped flowers before a leaf shows on the plant. 50c, 75c and $\$ 1.00$ each. 


\section{Pomegranate}

A large shrub or small tree, which is grown for both fruit and flowers. Small shining dark leaves with scarlet flowers that are followed by large round fruit that ripens in late summer and fall. Two-year-old plants, 50c and 75c.

\section{Purple Leaf Plum}

(Prunus Pissardii)

Purple foliage. Double flowers cover the tree before any leaves are out. $75 \mathrm{c}$ and $\$ 1.00$ each.

\section{Redbud}

One of the most showy large shrubs or small tree. The branches are completely covered with lavender flowers early in the spring before the foliage appears. Very effective when used as a background for evergreens or lower-growing shrubs. 3 to $4-f$ t. plants, $75 \mathrm{c}$ and $\$ 1.00$ each.

\section{Snow Ball}

Well known; the large globes of pure white flowers appear in the spring. $50 \mathrm{c}, 75 \mathrm{c}$ and $\$ 1.00$.

\section{Spirea Anthony Waterer}

Beautiful low-growing, bushy, profuse blooming plant; color beautiful rose shade. $75 \mathrm{c}, 50 \mathrm{c}$ and $35 \mathrm{c}$ each.

\section{Spirea Billardii}

One of the best pink flowering shrubs, fast grower, profuse bloomer; fine for beds; grows 4 to 5 feet. $75 \mathrm{c}, 50 \mathrm{c}$ and $35 \mathrm{c}$ each.

\section{Spirea}

(Chinese Blue)

A shrub of moderate compact growth with gray downy leaves. Flowers bright blue, small, but in large clusters in axils of leaves; bloom all through summer. Very valuable for its unusual color and long flowering period. $35 \mathrm{c}, 50 \mathrm{c}$ and $75 \mathrm{c}$ each.

\section{Bridal Wreath Spirea}

\section{(Van Houttii)}

A beautiful shrub, with large panicles of elegant white flowers in spring. 35c, 50c and $75 \mathrm{c}$ each. Balled specimen plants, $\$ 1.00$ and $\$ 2.00$.

\section{Salvia, Hardy}

A beautiful shrub of recent introduction; flowers a beautiful red, very hardy and flowers from early spring until frost kills the flowers; the leaves stay green all winter. This shrub can be planted in any kind of soil and will stand more drought than any plant we grow. 35c, 50c and $75 \mathrm{c}$ each.

\section{Tamarix (Hispida)}

Tall, graceful, with juniper-like foliage and a great profusion of delicate pink flowers covering the entire surface. A handsome shrub at all seasons. $75 \mathrm{c}$ and $\$ 1.00$ each.

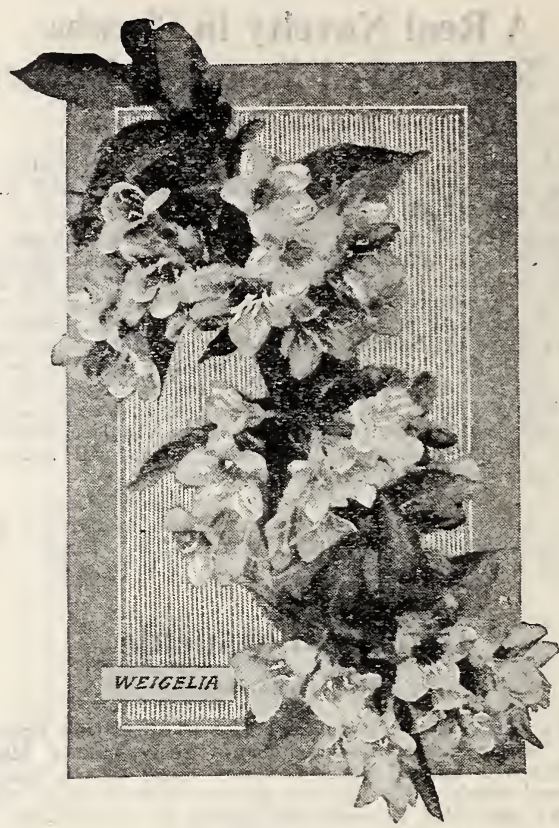

\section{WEIGELIA ROSEA}

Elegant, with fine rose-colored flowers, hardy, and blooms when quite small. One of the most popular and satisfactory shrubs. 35c, 50c and 75c each.

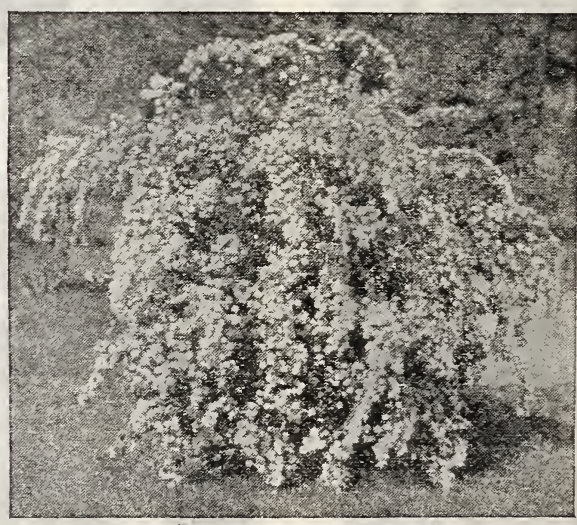

SPIREA VAN HOUTTII

\section{$\$ 1.00$ Special Shrub Collection}

\section{One-Year Field Grown Plants}

Five fine flowering shrubs: Bridal Wreath, Weigelia, Abelia, Crepe Myrtle, Hardy Salvia. A pretty bed of shrubs. Parcel post paid for only $\$ 1.00$.

No changes made. 


\section{HARDY PERENNIAL PLANTS}

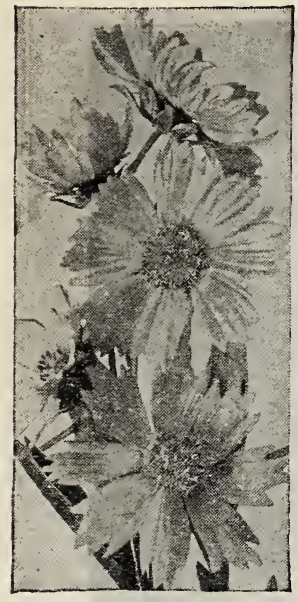

COREOPSIS

\section{Coreopsis}

The perfect strain of a long popular hardy plant. Flowers are rich golden yellow, borne in great profusion nearly the entire summer. $15 \mathrm{c}$ each; $\$ 1.50$ per dozen.

\section{Daisy, Shasta}

The largest and perfectly hardy daisy grown; of spreading habit, a small plant will spread and produce ten to twentyfive blooms the first year and can be separated and make twenty-five plants the next season. Well shaped plants, $15 \mathrm{c}$ each; $\$ 1.50$ per dozen.

\section{Gaillardia}

\section{(Blanket Flower)}

Makes one of the most gorgeous and prodigal displays of all perennials. Flowers often measure three inches in diameter, on clean, two-foot stems. A hardy center of deep maroon is thickly bordered by petals of orange and yellow, ringed by circles of crimson, red and maroon. Poor soil will do, and a constant show is assured from June till frost. $15 \mathrm{c}$ each; $\$ 1.50$ per dozen.

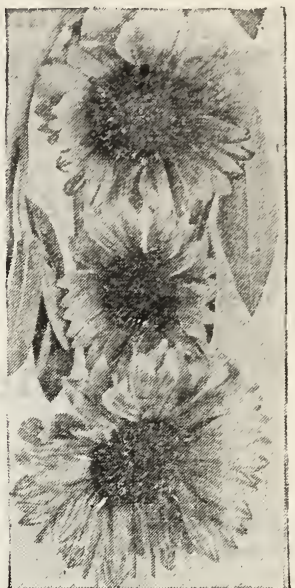

GAILLARDIA

\section{Hardy Asters}

(Or Cluster Daisy)

Lavender blooms borne in great profusion during late summer and fall. Very easily grown and a valuable fall flowering perennial. 18 to 24 inches tall. 25c each.

\section{Hardy Ageratum}

Late summer and fall, lavender blue; fine for border. Large plants. $25 \mathrm{c}$ and $35 \mathrm{c}$ each.

\section{Hardy Sweet Peas}

Very showy and persistent flowering, medium tall growing vine for covering low fences, rockeries, etc. Pink and red. $25 \mathrm{c}$ each.

\section{Hibiscus, Hardy}

A desirable, showy plant, succeeding in any sunny position. Grows 3 to 4 feet high, large foliage and great showy single flowers of delicate colorings. Colors: White with crimson eye, pink red. 35c each. Stronger roots, 50c each.

\section{Hollyhocks}

Time-honored, stately, majestic, hardy plants, which are a necessary part of every old-fashioned garden and should also find a place interspersed with shrubbery, as clumps on the lawn or in the mixed border, where their colossal spikes of bloom produce bold and showy effects, which cannot be secured with any other flowering plant. We offer these in the following colors: Double, maroon, white, pink, yellow and red. $25 \mathrm{c}$ each; $\$ 2.50$ per dozen.

\section{Liatris}

(Blazing Star or Gay Feather)

A splendid late summer flowering plant with purplish blue spikes that retain their color all winter when cut and dried. $25 \mathrm{c}$ each.

\section{Pampas Grass}

Well-known perennial, succeeding most everywhere. A showy and ornamental species with large feathery plumes. 30c.

\section{Mallow Marvels}

\author{
(Or Hardy Hibiscus)
}

Very hardy and showy shrub-like perennial, growing 3 to 4 feet, large foliage and flowers produced all summer and fall. Red and pink. Large plants, $35 \mathrm{c}$ and $50 \mathrm{c}$.

\section{Phlox, Hardy}

A hardy flowering, low-growing plant with very pretty bright colored flowers by the hundred; blooms early and all summer. Named varieties:

MISS LINGARD.-Best pure white.

PROFESSOR VIRCHOW.-Bright carmine.

RYNSTONE.-Effective carmine-rose.

LAVENDER QUEEN-Lavender, strong grower, free bloomer.

Fine Plants, 25c each; $\$ 2.50$ per dozen.

\section{Pinks, Hardy}

We have a fine assortment of these beautiful hardy flowering Sweet Pinks in assorted colors at $15 \mathrm{c}$ each; $\$ 1.50$ per dozen.

\section{Tritoma or Fire Poker}

Beautiful for yard planting or in shrub beds. Strong clumps. $35 \mathrm{c}$ each.

\section{Sweet Williams}

All colors and shades. One-year-old plants, 15c each; twoyear-old plants, $25 \mathrm{c} ; \$ 2.50$ per dozen.

\section{TO OUR PATRONS}

The stock and stems listed on this page are hardy and should with ordinary care and attention carry or live through the winter as well as the summer, or live through the winter as well as the summer, better plants with each year. We hope you will try at least a few of these varieties. 


\section{VINES AND CLIMBERS}

\section{Trumpet Vine}

For covering unsightly places, stumps, rockwork or wherFre will be found very useful. The flowers are large, attractive and borne profusely after the plants attain a fair size. Dark orange, red two-year-old vines, $50 \mathrm{c}$ and $75 \mathrm{c}$.

\section{Virginia Creeper}

The best and quickest growing variety for covering trees, trellises, etc. Large leaves with five leaflets, assuming brilliant yellow, crimson and scarlet colors in the fall. Clings to stucco and brick walls. Two-year-old vines, 50c.

\section{Climbing Vines}

\section{Boston Ivy}

(Amelopsis Yeitchii)

Vigorous creeper, desirable on walls, stumps, fences, etc. $50 \mathrm{c}$ and $\$ 1.00$ each.

\section{Clematis Henrii}

Graceful, with large white flowers. $75 \mathrm{c}$ and $\$ 1.00$ each.

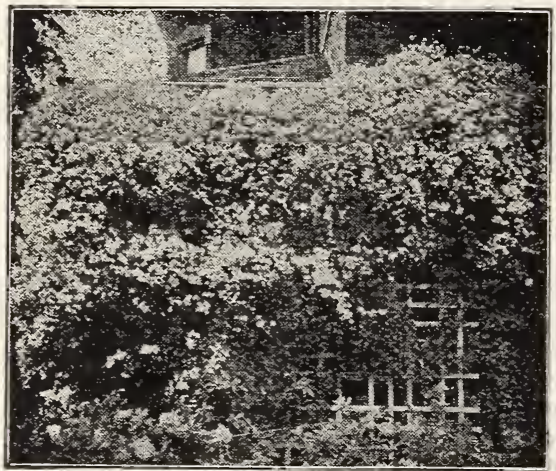

\section{Clematis Paniculata}

Hardy climber. White, fragrant, star-shaped flowers. Twoyear-old plants, $50 \mathrm{c}$ each.

\section{Clematis Jackmanii}

Very free-flowering and one of the most popular. Flowers large, of an intense violet purple. Two-year-old plants, $\$ 1.00$ each.

\section{English Ivy}

One of the few evergreens. Clings to any tree or wall, brick or wood. Small plants, $15 \mathrm{c}$ each; large plants, $50 \mathrm{c}$ and $\$ 1.00$ each.

\section{Honeysuckle}

(Hall's Japan)

Flowers pure white, changing to yellow; very fragrant: nearly evergreen; hardy and valuable. 50c.

\section{Honeysuckle}

(Scarlet Trumpet)

Hardy and Vigorous, 50c.

\section{Wistaria (Purple)}

A large, strong grower, with long racemes of purple flowers. 50c and $\$ 1,00$ each.

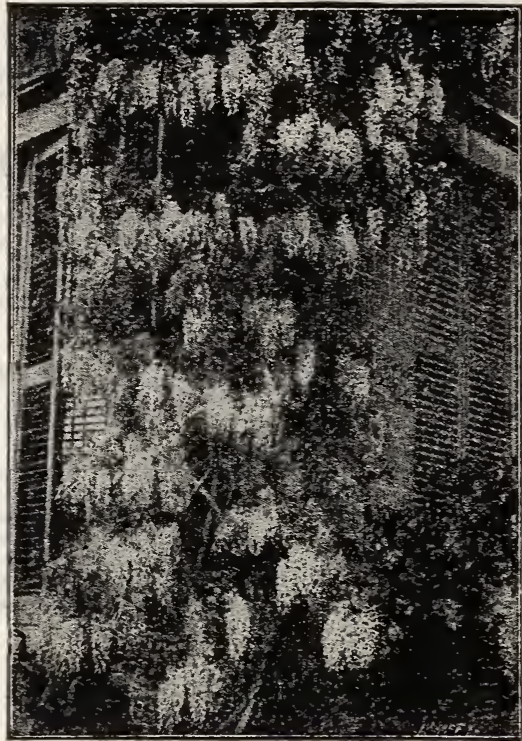

WISTARIA

\section{Wistaria (White)}

A large, strong grower, with long racemes of white flowers. 50c and $\$ 1.00$ each.

\section{Kudzu Vine}

Fastest growing vine known, grows 50 to 75 feet. Large dark-green leaves; it bears small racemes of rosy-purple peashaped blossoms towards the close of autumn. A splendid subject for permanently covering verandas, dead trees, etc. $50 \mathrm{c}$ and $75 \mathrm{c}$ each.

\section{Queen's Wreath}

(Beauty Vine)-(Mountain Rose)

A lovely climber from Central Mexico with beautiful rosecolored flowers in racemes two feet long. The profusion of blooms is such as to give the resemblance of roses at a distance, hence the Mexican name, "Rosa de Montana." Described by its discoverer as the most beautiful climber he has ever beheld. This is moderately hardy with protection. The vines are killed to the ground by frost, but it quickly shoots up in the spring, and develops its flowers from June till frost. 50c each. Large, heavy roots, $\$ 1.00$ each.

\section{Parlor Ivy}

A lovely and thrifty climber for the house or window; grows very quickly and makes an abundance of pretty green foliage. 10 c each: 3 for 25 c.

\section{Mexican Morning Glory}

Very strong, growing, hardy vine. Flowers trumpet shape, a beautiful shade of pink. Blooms all summer. $25 \mathrm{c}$ and $35 \mathrm{c}$ each.

\section{Moon Flower Vines}

Ready to Sell March 18t to May 15th.

WHITE.-So called from its rare peculiarity of blooming best at night, although it also expands its flowers on dull days. They are pure white; 5 or 6 inches across, emitting a rich Jasmine-like odor. $10 \mathrm{c}$ each.

BLUE.-Intense violet blue, with reddish purple rays, six inches across. It blooms in the morning and on cloudy days. 


\section{ROSES}

\section{QUEEN OF YARD FLOWERS}

Brief Cultural Notes

To grow Roses for success and pleasure, location of rose bed, soil, planting time and pruning are important factors.

A light, open location, so there may be a free circulation of air and accessibility to sunshine for at least half or more of the day, is most important.

Any properly drained, moderatelyheavy to heavy soil spaded to a depth of 14 to 18 inches with a liberal application of well rotted dairy manure or bone meal should produce excellent results.

In the Southern States where severe freezes are infrequent, late fall and early winter plantings of both pot grown and field grown rose plants are considered desirable, although not imperative, as very good results are usually obtained from plantings made during the early spring months, February and early March.

Pruning is for improving the productive power and the appearance of the plant. Remove all dead, weak, overcrowded or otherwise useless shoots by cutting them clear away to the base of the plant or to their starting point on the older shoots. After this thinningout process, cut the remaining stems back about one-third to one-half being careful to have the stems appear as regularly arranged and the plant as well balanced as possible. About two weeks before the foliage begins to come forth or about the first to fifteenth of February, is considered about the proper time to prune roses, shrubs and trees.

Mildew and Black-spot are the two most common and destructive diseases of the Rose. Both cause most trouble during the early spring and fall and this can be traced to the variable weather conditions prevailing during these seasons. Neither disease is curable, but both are to a large extent controllable by the diligent and persistent applica-

tions of fungicides, such as Bordeaux Mixture, Scalecide, Sulfocide, Lime, Sulphur, etc. If you will address Lang's Nursery Department and give us an outline of your Rose troubles, we will gladly prescribe the proper treatment.

FIELD GROWN ROSES can not be had after March 15th. Time to plant all Field Roses, Shrubs and Trees: November 20 th to March 1st. Small Pot Roses can not be had before January 1st. Time to plant: January 1st to May 1st. Roses under this list: $75 \mathrm{c}$ each, $\$ 7.50$ per dozen; one-yearold, out of $21 / 2$-inch pots, 25 c each; $\$ 2.50$ per dozen.

\section{Yellow Shades}

CLAUDIUS DE PERNET: There is no doubt but what this is the best yellow rose in existence today. Long buds on long stem; strong field grown-\$2.00 each, pot roses $\$ 1.00$ each. See front cover.

ANTOINE RIVOIRE.-A handsome rose with large, full Camelia-shaped flowers. Color rosy-flesh on a yellow ground, shaded with a border of carmine.

LADY HILLINGDON.-At the Detroit Rose Show, this was awarded the sweepstakes over all yellow roses. It has long willowy stems; the buds are held upright; has a long slender pointed bud of brilliant deep golden-yellow. Awarded gold medal.

LUXEMBURG.-A deep copper-yellow, shaded with' coral; petals thick and leathery. See full color illustration on page 28. No pot size.

MRS. AARON WARD.-One of the most delightful roses of recent years in a color that catches the eye at once. Coppery-orange in the open bud, golden-orange when partly developed, pinkish-fawn of lovely shade when fully open, when it looks like a full fluffy silk rosette.

SUNBURST.-Best yellow to date, full long bud and double, free bloomer.

\section{Pink Shades}

PRISCILLA.-Large globular budg opening to a fine very double bloom, borne on strong long stems; lasts exception- ally well. For cutting. Color very deep pink, changing to soft rose pink.

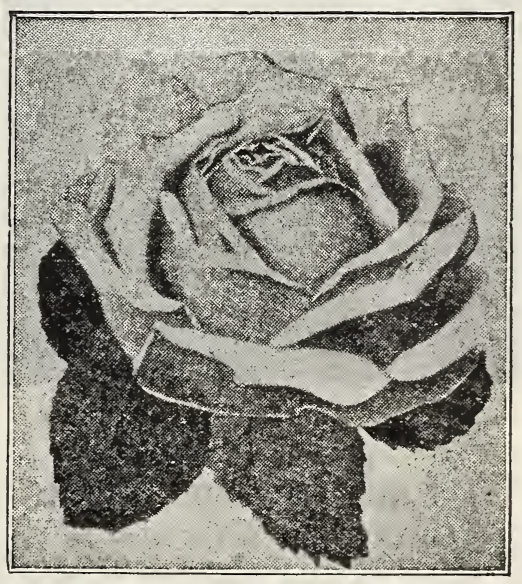

COLUMBIA

COLUMBIA. - It is a big Rose, the open flower measuring six inches. The color is a true pink, deepening as it opens to glowing-pink. A peculiarity of the variety is that the shades all become more intense until the full maturity of the open flower is reached and this color is enduring ; a great Rose.

JONKHEER J. L. MOCK.-This grand rose is the strongest growing, in the Hybrid Tea class. The blooms, which are 


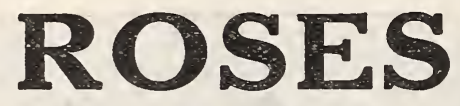

produced with the greatest freedom, are carried on stiff and erect stems and are of the largest size, of perfect formation and highly perfumed. Color clear imperial-pink; a glorious flower. Awarded two gold medals, one silver medal and five first prizes in Europe. We can confidently recommend this sterling novelty as a most valuable addition.

LOS ANGELES.-Originator's description: "Los Angeles is, by all odds, one of the finest roses ever introduced. The growth is very vigorous, and produces a continuous succession of long-stemmed flowers of a luminous flame-pink toned with coral and shaded with translucent gold at the base of the petals. The buds are long and pointed and expand into a flower of mammoth proportions, while the beauty of form and ever-increasing wealth of color is maintained from the incipient bud until the last petal drops. Pot roses, 35c.

COMMONWEALTH.-Bud large, long, pointed; flower large, open, double, very lasting; deep pink, solid color; borne singly on medium strong stem; moderate fragrance. Foliage sufficient, leathery, medium size rich green, disease resistant. Few thorns. Vigorous, upright.

\section{Salmon Shades}

MME. EDWARD HERRIOTT.-The bud is long, slender and pointed; the color is like sunshine on a copper red metal. A wonderful color combination; in effect a true salmon.

OPHELIA.-Described by the introducers as the most beautiful Rose of the century. The color is salmon-flesh, shaded with rose. The blooms are carried high on good stiff stems and are well shaped. It is strongly and delicately perfumed. The habit of growth is bushy and free-branching and the variety produces blooms freely.

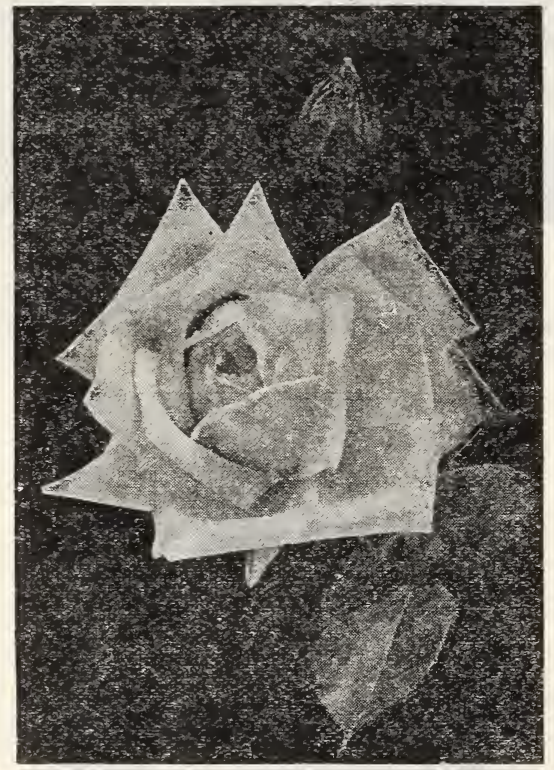

OPHELIA

\section{Red and Crimson Shades}

AMERICAN BEAUTY.-This first of all on the list is without doubt the American Beauty, the largest and best, the healthiest grower, the finest flower and the most fragrant of roses. We have alone thousands of this one kind, as there is :uch a demand for them that we always sold out before the season was over. Our stock consists of fine threeyear-old plants.

CRUSADER.-Blackish-crimson in color, a wonder. A big, strong-growing variety, robust and rugged in every characteristic. The growth is heavy and the flower stems are strong and heavy, producing very little blind wood. It is free-growing and free-flowering, and the blooms are truly characteristic of the variety-big and double, and, in color, a rich, velvety crimson. These large, heavily petaled blooms open perfectly and are amply supported by the strongnecked, heavy flower growths.

EDWARD MAWLEY.-A spiendid hybrid tea rose with immense buds and mammoth fully developed flowers. Color rich dark velvety crimson. In our opinion one of the best red roses grown.

ETOILE DE FRANCE.-It is a strong, vigorous grower with good dark foliage and its large flowers which are full and double and of beautiful form both in the buds as well as full bloom; flowers are borne on strong upright shoots in the greatest profusion. In color it is distinct from all Roses of its class, being of a rich, velvety crimson.

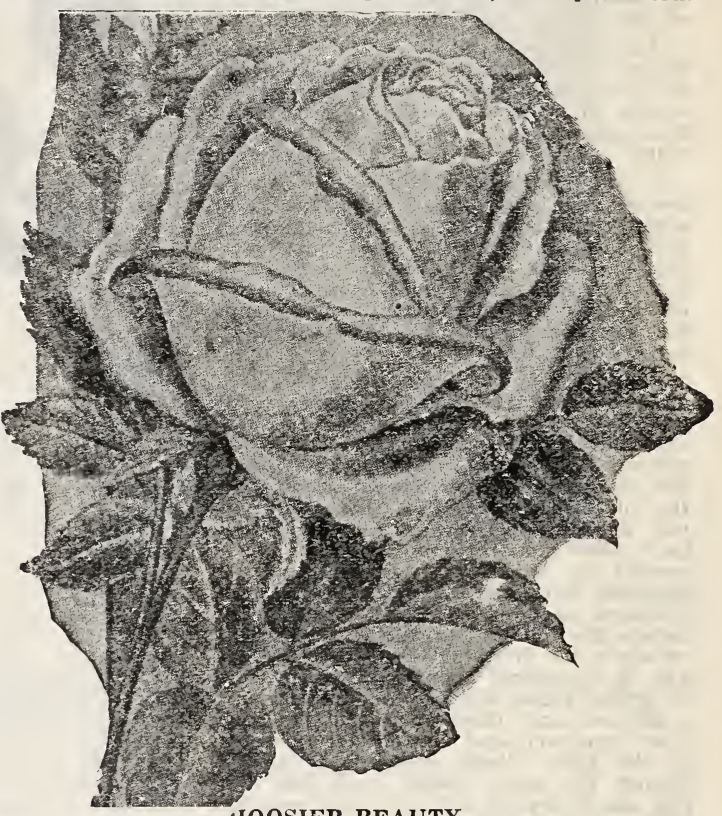

HOOSIER BEAUTY

FRANCIS SCOTT KEY.- "The rose for every garden of every American home." Named in honor of the writer of the "Star-Spangled Banner." This splendid rose produces intensely black grain scarlet-crimson blooms on strong shoots of sturdy erect growth, embellished with a foliage of the deepest green.

GENERAL McARTHUR.-One of the very best red bedding roses. General McArthur is as fragrant as a rose can be: has good sized flowers and blooms continuously. The bud, when first opening, is the brightest crimson-scarlet and the flower retains this perfect coloring until it drops its petals. Blooms continuously and gives fine stems for cutting. Its habit of growth is remarkably good, making strong, shapely plants that may be depended on for large flower shoots.

HADLEY.- In color it is a deep velvety crimson, retaining its brilliancy at all seasons of the year. The variety is double and buds are well formed. The fragrance is excelled only by American Beauty. It is strong, rapid grower and the flowers are borne on long, stiff stems.

HOOSIER BEAUTY.-A grand new Rose and one that will have many admirers. The flowers are a glowing crimson, with darker shadings which make its beauty indescribable. It is very fragrant and the flowers are produced on long, strong. stiff stems. The flowers have a texture like velvet. This Rose is very free-flowering. The bush is remarkably vigorous and sturdy in growth.

HYBRID TEA.-As the name implies it is a "Sensation," due to the color and habit of growth. Anyone that has seen Premier can imagine what this is like, being better in every way, color, foliage and growth. Buds long and pointed, opening full and double and retaining its color in the open flower. Blooms produced on long stiff stems well above the foliage and in great profusion. Color an entrancing shade of red.

\section{Standard Roses}

All Roses under this heading are for extra select plants, 2 and 3 -year-old, 50c each, $\$ 5.00$ per dozen. Pot Grown, $15 \mathrm{c}$ each, $\$ 1.50$ per dozen. If by parcel post, add $25 \mathrm{c}$ per dozen for large roots and $15 \mathrm{c}$ per dozen for pot roses. 


\section{ROSES}

(Continued)

\section{White Shades}

KAISERIN AUgUSTA VICTORIA (A Hybrid Tea Rose), Soft, pearly-white, lightly tinted with lemon in the center, remarkably fragrant; a strong, healthy grower, with beautiful foliage. The flowers are borne on long stems. This is the best white Rose for outdoor planting, as it gives more flowers than any we ever knew. See page 28 for full color illustration.

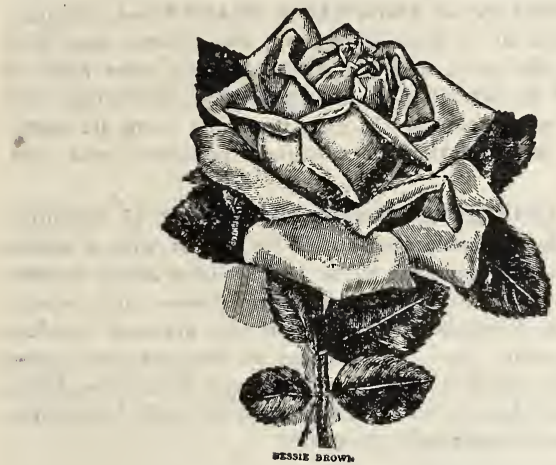

KAISERIN AUGUSTA VICTORIA

THE BRIDE._"The Bride" is a pure white Rose of large size and most perfect form. It has delicious Tea fragrance, a strong growing, free blooming Rose.

WHITE IKILLARNEY.-The same in shape and form as Pink Killarney, only a pure white; buds long and pointed; petals very large, making a very large rose when open; a free bloomer and strong, healthy grower.

WHITE LA FRANCE.-Pearly-white, shading to rose; like La France in other characteristics.

WHITE MAMAN COCHET.-A pure white, hardy, everblooming Rose and one of the most valuable in the entire list. For size, hardiness, vigor, profusion of blooms, it is unsurpassed. A superb summer Rose for cut flowers.

\section{Pink Shades}

BRIDESMAID.--Another Rose of American origin, a "sport" from C. Mermet, and possessing all the good qualities of the parent variety. It surpasses it in color, being a deep brilliant pink and constant bloomer under all conditions.

MADAME CAROLINE TESTOUT. - Clear bright satinypink; flowers very large and extremely showy.

PINK KILLARNEY. - The color is an exquisite shade of deep shell pink. It is free in growth, and heavy shoots which are crowned with buds.

PINK LA FRANCE.-The flowers are very large, double, delightfully fragrant, light silvery pink; blooms continuously throughout the season and stands first among the Roses for our climate.

PINK MAMAN COCHET.-The growth is free and vigorous. very free blooming; flowers of splendid substance are a delightful shade of deep pink. The buds, long and pointed, full and firm, lasting a long time when cut.

PINK RADIANCE.-In this variety we have an absolutely distinct and magnificent Rose of the highest excellence. It is a strong, vigorous grower, of free and erect branching Flowers very large and massive, of a lovely glowing pink color, distinctly shaded to white at base of the petals. The outer petals are shell-shaped and extremely large, giving a half opened flower of great spread. This is a fine American pedigreed sort. A fine garden Rose.

JONKHEER J. L. MOCK.--Called the Giant Pink from Holland. Of distinctive merit, being an extremely strong grower, one of the strongest of the Hybrid Tea class, blooming as it does with the greatest freedom, the buds carried on long, stiff erect stems, of the very largest size carried on long, stiff erect stems, of the very largest size perfect formation. Very fragrant. Color, clear imperial pink on the order of La France. This Rose has produced a sensation wherever grown.

\section{Yellow Shades}

ETOILE DE LYON.-One of the best and most beautiful yellow Tea Roses for - ne or the best and most beautiful bloom the entire year by proper treatment. The flowers are of good size, deep, full, very sweet-scented, rich, golden yellow.

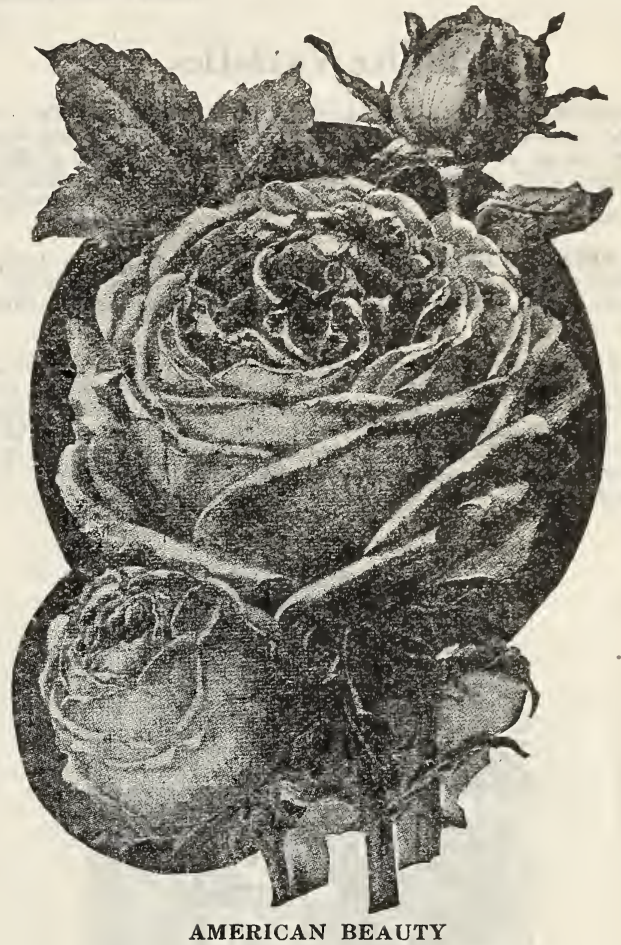

\section{Red and Crimson Shades}

HELEN GOULD.-A most profuse bloomer and luxuriant grower. Long beautiful buds and full double flowers of rosy carmine. Color nearest shade to the famous American Beauty. Flowers borne well above the foliage. Helen Gould should be in every planting because of its hardiness, beauty and profuse blooming qualities.

RED RADIANCE.-A glowing crimson sport of Radiance with all the magnificent qualities. The enormous globular flowers on heavy canes are a sight to be long remembered. The color is dazzling crimson-scarlet.

GUERS AU TEPLITZ.-For intense and dazzling color, there is no rose to compare with this splendid kind. The flowers a large and handsome moderately double of splendid substance and produced in great profusion during the whole growing seasons. Color, a fiery crimson with a dark velvety sheen. A vigorous grower and desirable garden rose.

\section{Hybrid Perpetual Roses}

\author{
Field Roses, 75c; Pot Roses, $25 \mathrm{c}$
}

PAUL NEYRON.-Deep rose; flowers of immense size indeed, many claim this to be the largest rose grown.

PINK FRAU KARL DRUSCHKI.-This is a pink, or rather a tender rose-colored form of the popular white Frau Kar Druschki, possessing not only the exquisite form, large size and remarkable free-flowering habits of its parent, but in addition to this, it is also highly perfumed, a Rose worthy of a place in every garden.

WHITE AMERICAN BEAUTY (Frau Karl Druschki).-This fragrant White Rose has become renowned as the very highest type of its class and the best snow-white rose ever introduced. It is an extraordinarily strong rrower, and has the vigor and hardiness of an oak. Its magnificent flowers are nothing less than glorious-immense in size and produced with great freedom. The color is a marvelous white, without a tinge of yellow or any other shade. A true paper-white, the standard by which all white roses are judged. 


\section{CLIMBING ROSES}

All field-grown Climbing Roses, 75c each, except where noted; Pot Roses, 25c, except where noted.

\section{White Varieties}

CLIMBING KAISERINE AUGUSTA VICTORIA.-The first white, hardy, ever-blooming climber. The flowers are extra large, deep, double, of excellent substance and are produced on long, stiff stems, like a forcing rose. The buds are long and pointed; the fragrance is delicious. Blooms continuously the first year.

CLIMBING WHITE MAMAN COCHET.-Here we have a climbing form that will become as popular a climber as its parent has as a bush rose. Grand, huge white flowers tinged pink.

SILVER MOON.-Different from all other roses. Flowers are large, single, four and $a$ half inches in diameter. Pure white in color. Petals of great substance, beautifully cupped. The large bunch of yellow stamens in the center adds to its attractiveness. The flowers are borne on long stems 12 to 18 inches long and are delicately perfumed. The plant is a strong grower, with large, glossy, green foliage.

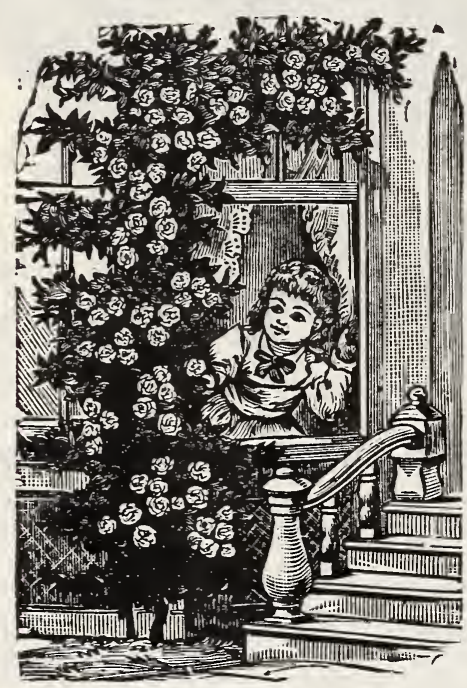

CLIMBING AMERICAN BEAUTY

\section{Red Varieties}

CLIMBING GRUSS AN TEPLITZ.-A climbing form of Gruss an Teplitz. Unquestionably one of the finest climbing roses ever introduced. The color when first opening is very dark rich crimson, quickly changing to bright scarlet, shading to velvety fiery red. The flowers are very showy and handsome. Remarkably healthy and vigorous; almost immune from all diseases.

PAUL'S SCARLET CLIMBER.-Brilliant vivid scarlet; color maintained without burning or bleaching until the petals fall. Flowers medium semi-double, produced in clusters, and covers bush from top to bottom. This is without question the most important addition to our climbing roses.

CLIMBING AMERICAN BEAUTY.-A seedling from American Beauty with Wichuriana and Tea blood in its veins. Same color, size and fragrance as American Beauty, with the addition of the climbing habit; good foliage and better blooming qualities. One plant of this new rose will produce twenty times as many flowers in June as the old American Beauty, besides blooming occasionally during the summer; blooms 3 to 4 inches across; has proved perfectly hardy and stands heat and drought as well as any rose in our collection. Large plants, $\$ 1.00$ each.

\section{Pink Varieties}

AMERICAN PILLAR.-Magnificent climber, dark foliage held well into the winter months, making this oplendid rose almost an evergreen. Flowers large, single, rich rosy-pink, with glint of white at center.

TAUSENDSCHOEN, or THOUSAND BEAUTY.-A climbing rose that comes to us from Germany. The flowers upon first opening are the most delicate shade of pink ever seen in a rose, might be described as a white delicately flushed pink changing to rosy-carmine. It gets its name from its many flowers and the variation in coloring; beautiful, and very popular.

Climbing COLUMBIA (Hybrid Tea).-Sport of Columbia and has all the desirable features of its parent with a strong climbing tendency, growing 10 to 15 feet in a single season. Foliage deep glossy green, immune from disease and insects. Hardy in any location. Blooms with the greatest freedom the entire season. Buds and blooms of immense size often measuring six inches in diameter, of perfect formation, borne singly on long shoots. Color clear imperial pink, beautifully dark-veined and delightfully fragrant.

\section{Yellow Varieties}

MARECHAL NEIL.-The immense size, dark, golden-yellow color of Marechal Neil is familiar to all. Peerless in color, unexcelled for size, perfect in form, after more than a quarter of a century it still remains the ideal climbing tea rose. Large, fine plants, $\$ 1.00$ each; Pot Roses, $25 \mathrm{c}$ each.

\section{The Polyantha Roses}

A type of Rose which is very popular for bedding purposes. They form shapely, compact, bushy specimens, about 18 inches high, producing in great profusion from early spring until severe frost immense trusses of small flowers. Field Roses, 75c each; Pot Roses, 25c each.

BABY DOLL or TIP TOP.-Brilliant golden-yellow, tipped with clear, bright cerise ; lovely miniature "Sweetheart" buds and blooms of perfect form. Borne singly, in erect panicles; foliage very handsome,

BABY DOROTHY, PINK BABY RAMBLER.-A prolific producer of pure pink flowers. This rose has all the good qualities of the Crimson Rambler.

BABY TAUSENDSCHOEN.-Its flowers are large and so much like "Tausendschoen." It is a bush form of the "Climbing Tausendschoen" or "Thousand Beauties," having all the charms in the variable coloring in its flowers that its parent has.

CECIL BRUNNER.-The most beautiful of all Polyantha or Baby Roses. Color bright salmon pink.

ORLEANS (an Improved Baby Rambler).-The color is irresistible, being deep cerise or geranium pink with distinct showy center of pure white. This Rose has taken Europe by storm.

LE MARNE.-Dwarf, perpetual flowering. Semi-double flowers, bright salmon-rose at the edges, rosy blush inside. Blooms abundantly and continuously in bouquets of 15 to 40 flowers. 


\section{Ornamental Evergreens and Hedge Plants}

\section{Arborvitaes}

AMERICAN ARBORVITAE.-This is the fastest growing and most ornamental evergreen grown; it is used best as a lawn in growth but the loose, graceful kind. 50c, $\$ 1.00$ and $\$ 2.00$. CHINESE ARBORVITAE COMPACTA.-10 to 12 inches high, 50c each; 12 to 18 inches, $75 \mathrm{c}$ each; 18 to 24 inches, $\$ 1.00$ each; large plants, $\$ 2.00$ to $\$ 5.00$ each.

BERCKMÁN'S GOLDEN DWARF ARBORVITAE,-\$2.50 to $\$ 10.00$ each.

CHINESE GOLDEN ARBORVITAE-Small, erect; compact foliage; tinted with gold. $\$ 1.50, \$ 2.50$ and $\$ 5.00$ each. ROSEDALE HYBRID ARBORVITAE. -10 to 12 inches high. 50c each; 12 to 18 inches, $75 \mathrm{c}$ each; 18 to 24 inches, $\$ 1.50$ each: 24 to 30 inches, $\$ 2.00$ each.

BOXWOOD.-Two-inch pots, 15c; 3-inch pots, 25c; 4-inch pots, 50c; 5-inch pots, 75c and $\$ 1.00$ each. Large fieldgrown plants, $\$ 2.00$ to $\$ 10.00$ each.

ARIZONA BLUE CYPRUS. -12 to 18 inches, $\$ 1.50$ each 18 to 24 inches, $\$ 2.00$ each; 24 to 30 inches, $\$ 2.50$ each; 36 inches and over, $\$ 1.00$ per foot in height. Large plants must be balled in earth.

\section{Euonymus}

GOLDEN EUONYMUS. -10 to 12 inches high, 50c each. EUONYMUS JAPONICA.-A very handsome evergreen for single shrubs or planting, very effective as background against the house, a splendid hedge plant. Will grow 6 to 10 feet if allowed; not a very rapid grower but very hardy and of long life, leaves dark green and glossy, thick and stays green all winter. No better evergreen shrub for any and all purposes. 8 to 10 inches from $2 \frac{1}{2}$-inch pots, $121 / 2 \mathrm{c} ; 12$ to 15 inches, $25 \mathrm{c} ; 18$ to 24 inches, $35 \mathrm{c} ; 24$ to 30 inches, $50 \mathrm{c} ; 30$ to 36 inches, heavy, $75 \mathrm{c}$.

SILVER LEAF EUONYMUS. -8 to 12 inches high, 35c; 12 to 18 inches high, $50 \mathrm{c}$ and $75 \mathrm{c}$ each.

EUONYMUS SEIBOLDI. -10 to 12 inches high, 50c each: 15 to 20 inches high, 75c each.

MAGNOLIA GRANDIFLORA.-Tree has large, bright green foliage and immense white flowers of great beauty and fragrance; it is native to Southern Texas, 2 to 3 feet, $\$ 1.50$; 3 to 4 feet, $\$ 2.50$ to $\$ 5.00$; large specimen plants, balled, $\$ 7.50, \$ 10.00$ and $\$ 15.00$.

CAPE JASMINE.-One of the most popular Southern shrubs ; flowers are most beautiful and very fragrant, white buds, leaves are dark green and glossy. Pot plants, 25c each: field-grown plants, 50c, 75c and $\$ 1.00$ each.

\section{Ligustrum}

LIGUSTRUM JAPONICUM.-2 to 3 feet, 35c each; 3 to 4 feet, 50c each, and 4 to 5 feet, $\$ 1.00$ each.

LIGUSTRUM LUCIDUM.-10 to 12 inches high, 50c; 12 to 18 inches high, $75 \mathrm{c}$ and $\$ 1.00 ; 18$ to 24 inches high, $\$ 1.50$ to $\$ 2.00$ each.

LIGUSTRUM NEPULENSE.--Low-growing, very heavy wax leaf, spreading fine for low evergreen. Plants 12 to 15 inches, $50 \mathrm{c} ; 18$ to 20 inches, $\$ 1.00 ; 24$ inches, $\$ 2.00$ each.

LIGUSTRUM WAX.-Medium height, large heavy leaves, fine showy plants; 12 to 15 inches, $50 \mathrm{c}$ each; 18 to 20 inches, $\$ 1.00$ each ; 24 inches, $\$ 1.00$ each.

CALIFORNIA PRIVET. -12 to 18 inches, 10c, $\$ 1.00$ per dozen, $\$ 8.00$ per $100 ; 11 / 2$ to 2 feet high, 15c, $\$ 1.50$ per dozen, $\$ 10.00$ per $100 ; 2$ to 3 feet high, 20c, $\$ 2.00$ per dozen, $\$ 15.00$ per $100 ; 3$ to 4 feet high, 35c and 50c each, $\$ 25.00$ per 100 .

AMOOR RIVER PRIVIT (South) -12 to 18 inches high, $10 \mathrm{c}$, $\$ 1.20$ per dozen, $\$ 8.00$ per $100 ; 18$ to 24 inches, bushy, 25c each, \$2.50 per dozen, $\$ 15.00$ per $100 ; 2$ to 3 feet, $35 \mathrm{c}$ each, $\$ 3.50$ per dozen, $\$ 25.00$ per $100 ; 3$ to 4 feet and up, 50c and $75 \mathrm{c}$ each, $\$ 4.00$ to $\$ 6.00$ per dozen, $\$ 30.00$ to $\$ 50.00$ per 100 . This is a beautiful busy stock and the best hedge plant grown. PITTISPORUM TOBIRA.-One of the best evergreen shrubs. Well adapted for trimming, as it grows round and compact. Balled and burlapped plants 12 to 18 inches, $\$ 1.50 ; 18$ to 24 inches, $\$ 2.50$.

ABELIA GRANDIFLORA.-A semi-dwarf evergreen shrub, with beautiful bright shining leaves which assume a metallic hue in fall and winter. Bears a profusion of flowers borne in clusters. Flowers small and trumpet-shaped, tinted outside a light lavender pink, with a waxy white within. Has a sweet fragrance and blooms from early summer until frost. Beautiful as a single plant or as a mass planting. It is the very finest blooming plant to border flower beds and cannot be surpassed as a hedge plant. Busy plants, 35c, 50c, 75c $\$ 1.00$ each. Specimen plants, busy and large, balled in soil $\$ 1.50$, \$2.50 and $\$ 3.50$ each. We cannot recommend this shrub too highly.

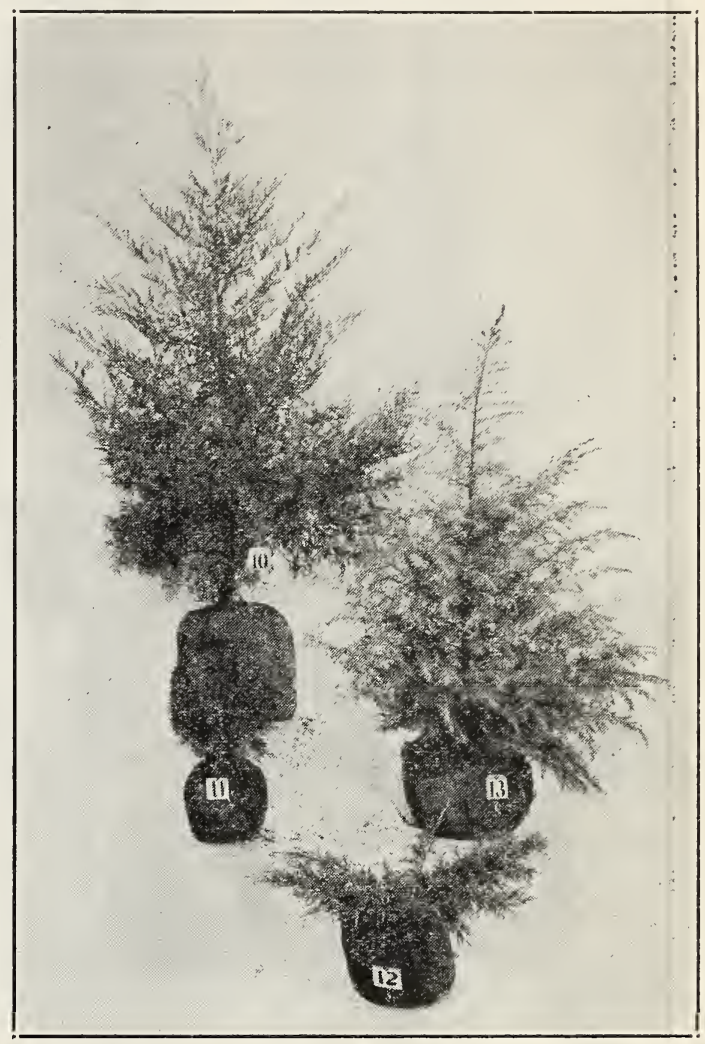

Red Cedar No. 10.-From Virginia. A well known ornamental tree: pyramidal shape: fine bronzy green foliage: very good for evergreen grouping; stands shearing well. Prices:

Mail order size

2 to 3 feet size

$\$ 3.00$

Arborvitae Bonita No. 11.-A beautiful globe-shaped evergreen, slow growth; fine for urn planting; desirable in location where low growing evergreens are needed. Prices:

Mail order size $50 \mathrm{c}$

8 to 10 inches $\$ 2.50$

Creeping Juniper No. 12.- The most satisfactory and hardy of the spreading or creeping juniper type. Beautiful in its distinctive grayish green color and irregular hat spreading growth; fine for terrace or low planting about foundations. Prices:

10 to 12-inch spread

18 to 24-inch spread

Cedrus Deodora No. 13.- One of the most beautiful evergreens grown in the South; brilliant for solitary effects through its grace and beauty; pyramidal in general outline limbs or branches drooping gracefully; foliage blue-gray color. Price:

2 to 3 feet Balled and Burlapped $\$ 5.00, \$ 6.00, \$ 7.50$ 3 to 4 feet Balled and Burlapped $\$ 6.00, \$ 8.00$

4 to 5 feet Balled and Burlapped $\$ 8.00, \$ 10.00$ 


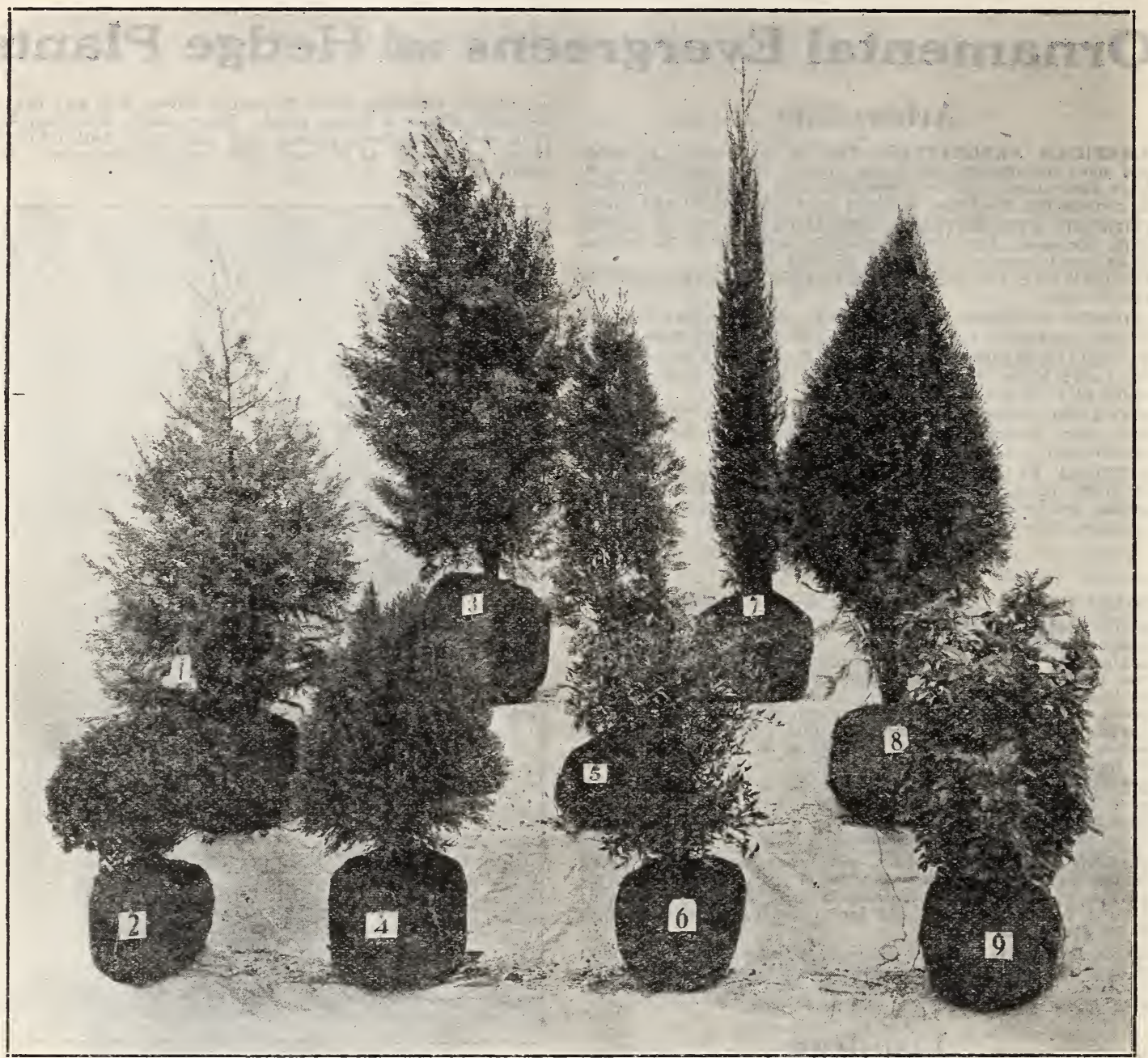

Arizona Cypress No. 1.-A handsome tree with brilliant silvery foliage, of pyramidal growth; stands shearing well. Fine for solitary effect. Also group planting. Price:

Mail order size

Balled and Burlapped

Prices on larger sizes on application.

$50 \mathrm{c}$

$\$ 2.50$

Dwarf or Low Dense Privet No. 2.-Dark green foliage, compact growth, good for low hedging; fine substitute for boxwood. Shears well. Thrives in any kind of soil; great for lawn design work, as lettering, urns, etc. Price:

Mail order size

$10 \mathrm{c}$

Sheared size suitable for urns, 10-12-inch diameter $\$ 1.75$

Chinese Arborvitae No. 3.-A well known evergreen of nice pyramidal growth; fine for grouping and background effect. Price :

Mail order size

1-2 ft. Balled and Burlapped

$25 c$

2-3 ft. Balled and Burlapped

Rosedale Arborvitae No. 4.--Bluish gray feathery foliage of soft effect; fine to plant in urns; also good to use either in shrubs or evergreen planting. Price:

Mail order size

$25 c$

12 to 18-inch Balled and Burlapped $\$ 1.50$

Arborvitae, Goldspire, No. 5.-Erect growth; foliage golden, suffused with green; very choice. Price:

12-18-inch Balled and Burlapped

$\$ 3.00$
Nandina Domestica (Chinese Bamboo) No. 6.-A very handsome small to medium height shrub with graceful light green foliage which turns to a most attractive bronzy red early in the winter. The small white flowers are produced in good sized erect panicles during the spring and are followed by crimson berries. A splendid addition to our evergreens and one that adds color at a time it is especially desirable. Outdoor pot grown plants 12 to 15 inches tall, $\$ 1.00 ; 18$ to 24 -inch bushes, $\$ 2.00, \$ 3.00$; extra heavy, $\$ 5.00$; balled and burlapped.

Italian Cypress No. 7.-Of columnar growth, very stately; adapted for colonial and Spanish homes: unsurpassed for entrance decoration or wherever height is desired; for entrance, chimneys, columns or on corner of houses. Price: Mail order size

$\$ 1.00$

Sizes to $5 \frac{1}{2}$, per foot 1.00

Baker Pyramidal Arborvitae No. 8.-Upright grower of columnar habit, foliage light green, very desirable for formal effects. Prices:

Mail order size

18 to 24-inch Balled and Burlapped

2.75

Mahonia Aquifolia No. 9.-A beautiful evergreen shrub, with smooth shining holly leaves; stems are crowned with clusters of bright yellow flowers in March or April. The leaf color varies throughout the year, assuming all shades of green which changes to a reddish bronze during the fall and winter. Prices, 18 to 24-inch, \$1.50, \$2.00, $\$ 2.50, \$ 3.50$. 


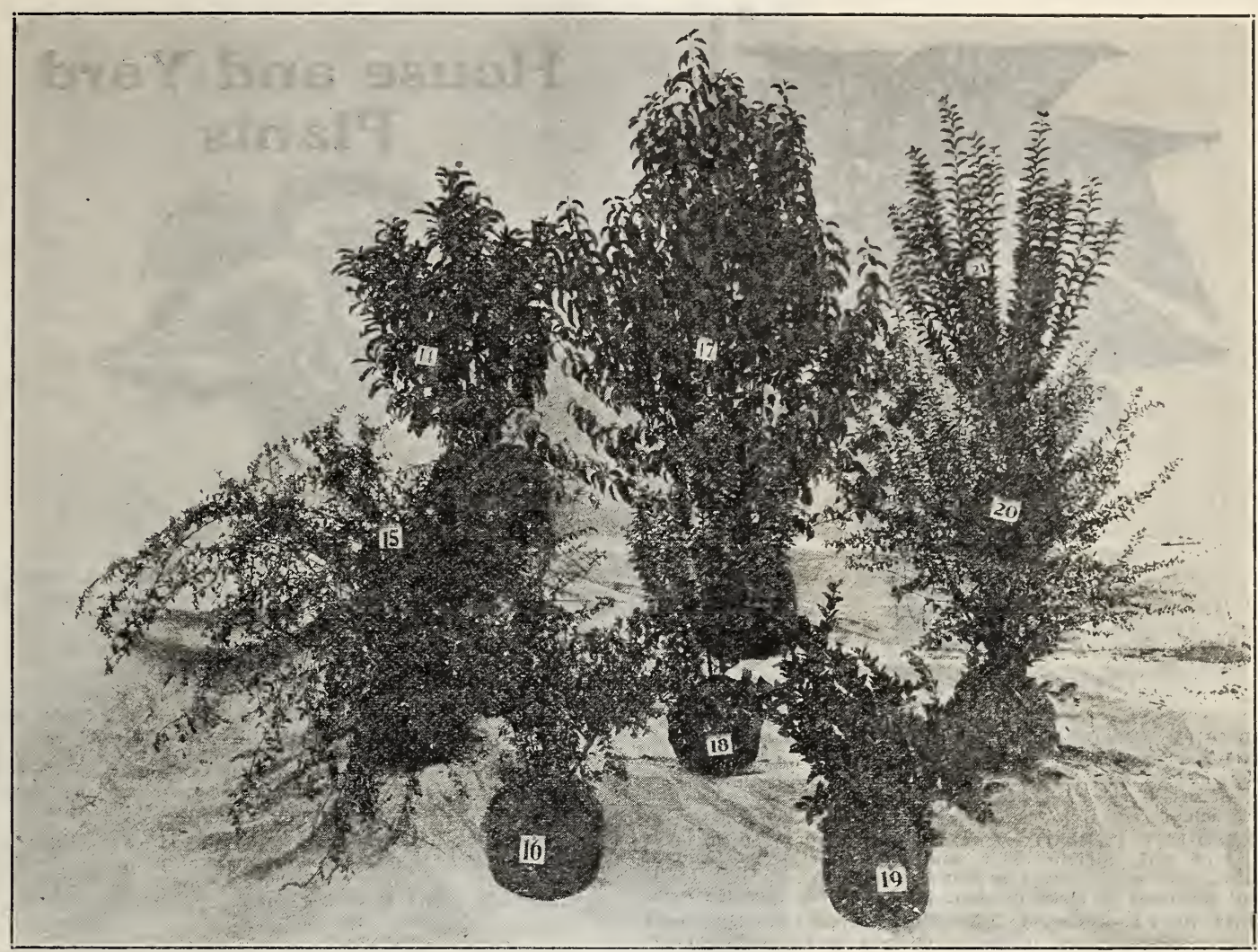

Photinia Serudlata No. 14.-Medium, tall, upright, growing evergreen shrub, with large, dark green leaves; new growth at first is dark red, gradually changing to green as foliage matures; some of the older leaves change to rich crimson during winter. Price each:

18 inches to 3 feet

$\$ 1.50, \$ 2.50, \$ 3.50$

Jasmine Humile No. 15-(Hulins Yellow Jasmine).-Fine border plant of medium height, evergreen, graceful slender branches of drooping habit; with abundance of small yellow flowers during spring and summer; very effective during winter months. Prices:

Mail order size

$25 \mathrm{c}$

2-year-old plant $50 \mathrm{c}$

Abelia Grandiflora No. 16. - A semi-dwarf evergreen shrub, with beautiful bright shining green leaves which assume a metallic hue in fall and winter. Bears a profusion of flowers borne in clusters. Flowers small trumpet-shaped, tinted outside a light lavender pink, with a waxy white within. Has a sweet fragrance and blooms from early summer until frost. Beautiful as a single plant or as a mass planting. It is the very finest blooming plant to border flower beds and can not be surpassed as a hedge plant. Bushy plants, 35c, 50c, 75c, $\$ 1.00$ each. Specimen plants, bushy and large, balled in soil, $\$ 1.50, \$ 2.50$ and $\$ 3.50$ each. See front cover page for full color illustration. We can not recommend this shrub too highly.

Ligustrum Japonica No. 17-(Japanese Privet).-Evergreen, large shrub or tree with leathery dark green glossy leaves: white flowers; followed by large clusters of purplish seed; unexcelled for tall hedge effects or backgrounds. Prices:

Mail order size. $25 c$

2 to 3 feet $50 \mathrm{c}$
Golden Privet No. 18. - Has all the splendid habits of the California Privet except that leaves are beautifully marked with golden yellow; excellent subject to mix with other evergreen to give variety of color. Prices:

Mail order size.

Larger

$\$ 1.00, \$ 1.50$

Ligustrum Lucidum No. 19 (Wax Privet).-An evergreen of spreading cut of compact growth. Leaves are dark green, leathery and glossy. Very desirable for foundation planting. Prices :

Mail order size $50 \mathrm{c}$ 12 to 18 -inch size $\$ 1.00$

Amoor River Privet No. 20.-This well known quick and easy growing hedge plant is the best in the South. Plant 12 to 18 inches apart. A very beautiful evergreen, dense in growth; dark green; will make a hedge in one year, or screen in unsightly buildings or fences in short time. Prices: Mail order size. $10 \mathrm{c}$ 2 to $3 \frac{1}{2}$ $15 \mathrm{c}$

\section{Change prices in hundred lots.}

California Privet No. 21.-Used almost exclusively for hedge planting; hardy and satisfactory, foliage dark green, almost evergreen. Prices:

Mail order size: 18 to 24 -inch, each $10 \mathrm{c}, \$ 1.00$ per dozen, $\$ 6.00$ per $100 ; 24$ to 30 -inch, each $15 \mathrm{c}, \$ 1.50$ per dozen, $\$ 8.00$ per 100 .

Pysracantha Lalandi.-Medium to large growing shrub adapted to most any soil or location; greatly admired for their reddish orange berry; like fruits which remain on the plant until spring.

Price

$\$ 1.50, \$ 2.50, \$ 3.50$ 


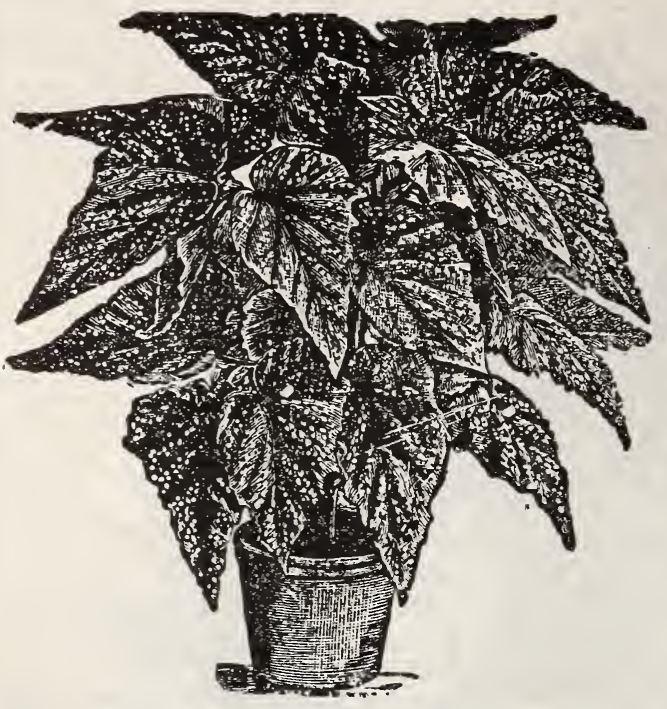

PRESIDENT CARNOT BEGONIA

BEGONIA GRACILIS LUMINOSA.-Foliage resembles a little that grand old variety, Vernon. Rich, glossy green, often shaded deep bronze. The flowers, when first opening, are of bright cherry, changing to a clear coral-red. $15 \mathrm{c}$ and $25 \mathrm{c}$ each.

PRESIDENT CARNOT.-A remarkably strong-growing variety of stiff, upright habit, somewhat in style of Begonia Rubra, but much larger in flower and leaf. Flowers beautiful coral-red in large pendant panicles. $15 \mathrm{c}$ and $25 \mathrm{c}$ each. ALBA PICTA.-(See cut). Very ornamental; has long, earshaped, medium-sized leaves of darkest green, with silvery spots. $15 \mathrm{c}$ and $25 \mathrm{c}$ each.

RUBRA.-Dark, glossy green leaves ; free-flowering; flowers rich coral-red in large pendant panicles. One of the best. $15 \mathrm{c}$ and $25 \mathrm{c}$ each.

ARGENTA GUTTATA.- Has the silvery-leaf blotches of Alba Picta with the form and beauty of Rubra; purplebronze leaves, oblong with silvery markings; flowers white on the tips of the stems, $15 \mathrm{c}$ and $25 \mathrm{c}$ each.

MRS. PATTON.-Very handsome, winter flowering. 25c and 50c each.

FEASTII.-Double curled; same as old Beefsteak Begonia, only beautifully curled, rapid grower, very ornamental. $25 \mathrm{c}$ and $50 \mathrm{c}$ each.

REX BEGONIA (Painted Leaf Begonia).-(See cut). These are grown for their handsome variegated foliage. For house culture, baskets, vases, etc., there is nothing more beautiful. We have a fine assortment. $35 \mathrm{c}$ and $50 \mathrm{c}$ each.

\section{Carnations}

CARNATIONS.-A flower for everybody; good for any occasion; easy to raise and a flower everybody likes. 15c each; \$1.50 per dozen. Large plants for winter blooming, 25c each. January 1st to April 15th.

WHITE SHADES.

White Enchantress.-Ours is the "Pure White" Western strain. We have an enormous quantity planted for cuttings which are in perfect condition.

White Perfection.-Still the most perfect in form and unsurpassed; of easy cultivation and a good producer. PINK SHADES.

Enchantress.-The great bread-and-butter variety of the floral world. Our cuttings are from carefully selected stock. Mrs. C. W. Ward.-A perfect formed flower with full center; color, deep pink, several shades lighter than Lawson, deeper than Winsor, having strong, erect stems 18 to 24 inches in length. The most popular pink variety on the market. SCARLET SHADES

Beacon.-Still "the" standard red; probably the freest carnation in existence. Our stock is in magnificent condition, without a sign of weakness or deterioration.

Aviator.-A new red, surpassing many of the old varieties: very large flower; long stem.

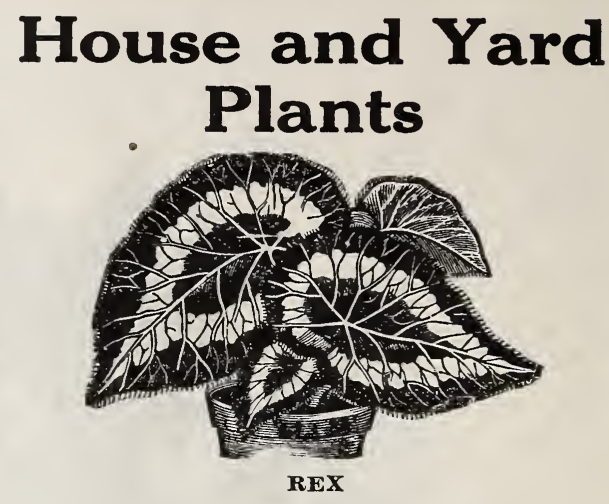

Artillery Plant

ARTILLERY PLANT.-A pretty little plant of drooping habit, resembling the Fern; it is a fine basket plant. $10 \mathrm{c}$ each.

\section{Acalphias}

ACALPHIAS-Sanderia (Chenille Plant).-One of the most striking flowering ornamental plants we have ever seen. It is of strong, free growth, with large dark green leaves, from each axil of which thick, rope-like spikes of velvety crimson flowers are gracefully suspended. 15c each, \$1.50 per dozen. Finest yard plant grown. Ready January 1st to April 15th.

TRIUMPHANS. - Very bright, ovate-pointed leaves, light red, shaded and marbled. A fine ornamental plant for bedding or pot culture, as showy as Coleus; its colors are bright and distinct. 15c each; $\$ 1.50$ per dozen.

\section{Alternanthera}

ALTERNANTHERA.-Beautiful dwarf plants of a compact habit, growing about six inches high, and admirably adapted for edging flower beds. A plant for the họt summer places. AUREA NANA.-Bright golden yellow, holding its color well the entire season. 50 c per dozen; $\$ 4.00$ per 100 .

AMOENA SPECTABILIS.-Crimson pink and brown; the finest and brightest. 50c per dozen; $\$ 4.00$ per 100 . Plant outdoors after April 15th.

\section{Banana Plant}

BANANA PLANT.-Nice strong roots of this beautiful plant will make a growth of 6 to 10 feet first year. $50 \mathrm{c}$ each; larger plants, $\$ 1.00$ each. Plants 6 to $10 \mathrm{ft}$., $\$ 2.50$ each. Express only.

\section{Petunias}

PETUNIAS, SINGLE.-The single Petunia is one of the finest bedding plants for massing, mixed borders, or for vases. The brilliancy and variety of its colors, combined with the duration of its blooming period, renders it invaluable for garden decoration.

Rose of Heaven.-Rich, rose-pink.

Rosy Morn.-Soft rose-pink, white throat.

Above named varieties, $75 \mathrm{c}$ per dozen.

Purple, red, crimson, blotched and white varieties, $10 \mathrm{c}$ each, $\$ 1.00$ per dozen.

PETUNIAS, GIANT DOUBLE-Are as large as Hollyhocks as double as double can be, with edges finely fringed; petals fluted and crinkled, intensifying and varying the colors with high lights and dark shadows, bringing out a richness and effect unmatched by crumpled velvet, which the flowers resemble. There is a variety of colors - selfs, blotched, veined, margined, etc. ; in short, these double Petunias are unsurpassed by any other strain in the world. Price, 15c each; $\$ 1.50$ per dozen. 


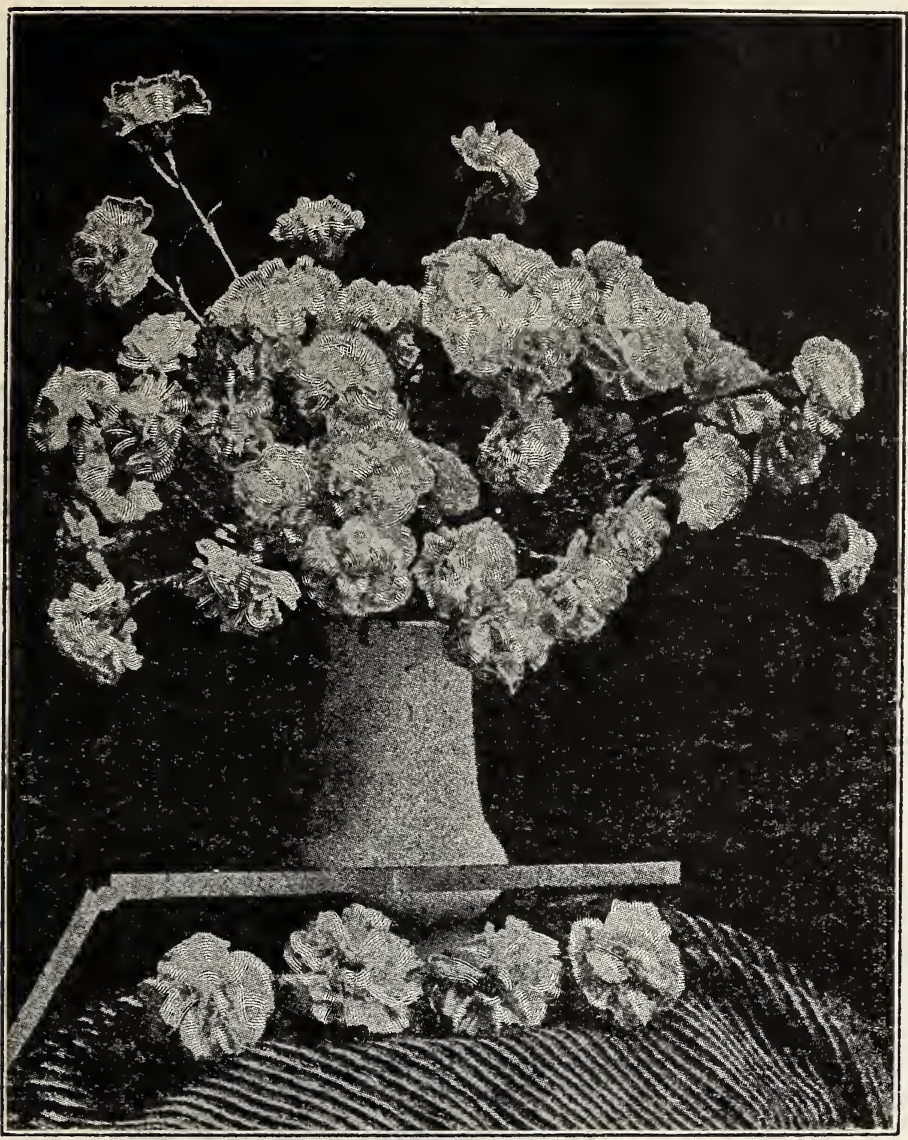

Plant a few of these Carnation plants in the open in March, grow flowers in the yard, then lift and put in pot or bucket in November and have flowers blooming in the home next winter. Everybody likes a Carnation and it is so easily grown.

\section{WHITE ENCHANTRESS}

\section{Parlor Ivy}

PARLOR IVY.-A lovely and thrifty climber for the house or window; grows very quickly and makes an abundance of pretty green foliage. $10 \mathrm{c}$ each; 3 for $25 \mathrm{c}$.

\section{Chrysanthemums}

CHRYSANTHEMUMS.--Should be planted April 1st till June 1st. Planting during this period they will produce good stocky plants with good quality flowers.

Dig the ground deep; put in quantities of manure. The Chrysanthemum is a heavy feeder; if fed well the flowers will be large and the plant strong.

DISBUDDING. - When your plant is eight inches high cut back to a height of six inches. Allow four shoots to grow from this main trunk. When these four shoots are four inches high, pinch out the terminal bud and save three or four branches that will spring from each of these limbs. Allow these last branches to attain a height of nine inches, then pinch back for the last time. Allow one bud (flower) to each stem, and that a terminal bud. Follow these directions carefully for best results.

\section{Price.-15c each; $\$ 1.50$ per dozen.}

\section{WHITE SHADES}

White Chieftain -A beautiful, incurving white of perfect shape. Certificated in Boston, Philadelphia and Chicago. Perhaps the finest incurved white commercial variety in cultivation today.

White Frick.-A large incurved variety of a medium long stem; flowers about mid-season and greatly admired by all lovers of Mums.

Smith's Advance.- This variety displaces every other of its date-first early; it is a lovely grower, free from tricks, and can be had in bloom at any time following a season of growth; a very high grade, pure white bloom: can be had late in September and into October; it has a stiff stem 3 feet and over, nice foliage and a beautiful formed flower very slightly reflexed.

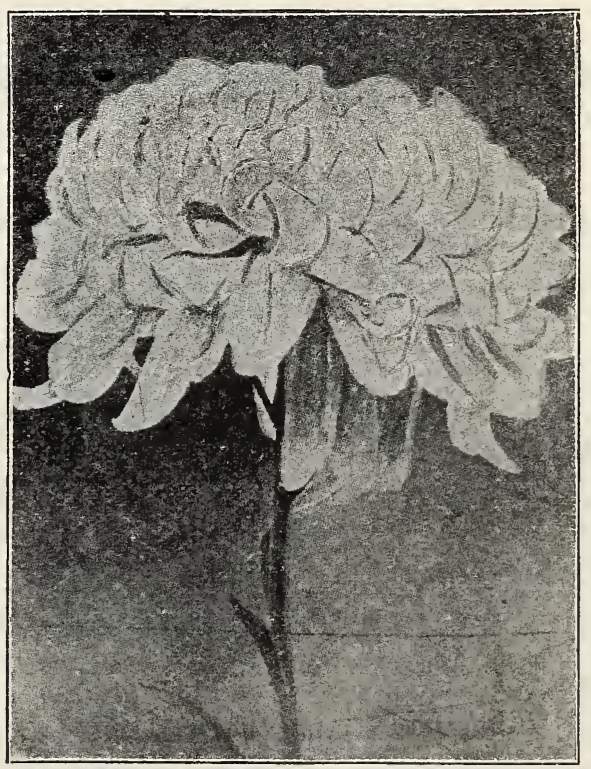

PACIFIC SUPREME 


\section{HOUSE AND YARD PLANTS-(Continued)}

\section{PINK SHADES.}

Chieftain.-The loveliest pink of them all. Ready October 20th, and keeps indefinitely without fading.

Pacific Supreme.-A longer stemmed, brighter colored Glory Pacific, maturing at the same time. Very early.

Dr. Enguehard.-Grand commercial variety; color, pink; stem and foliage perfect. Mid-season.

\section{RED SHADES.}

Black Hawk- - The largest and most beautiful dark crimson scarlet yet introduced; looks like crimson velvet, the very shade so much desired in Chrysanthemums; flowers of immense size on fine stiff stems. Late.

Harvard.-A splendid new variety of red Chrysanthemums of a strong upright growing habit, flowers large, very double and of darkest crimson color, reflexed petals and strongly recommended as an exhibition variety in its color.

BRONZE SHADES.

Glenview. - This large Japanese variety is of a dark bronze color, lining often shading to a little of the Indian Red color. Strong grower and good bloomer.

\section{YELLOW SHADES.}

Golden Wedding.-Nothing finer among yellows; shines like burnished gold; the standard for measuring color; $4 \frac{1}{1 / 2}$ feet. Mid-season to late.

Major Bonnafion.-This splendid, yellow commercial is still grown in large quantities; our stock is in perfect health. Three feet. Mid-season.

Chrysolora.-This splendid strong-growing, early-flowering "Mum" should be in every garden.

THE POMPOMS. - This lovely family of Chrysanthemums has been "coming" for years, and now it has certainly "arrived." No flower is quite so popular while it is in season and flower buyers anxiously look for its coming and regret when it can no longer be had, for the ladies all over the country realize that it is the most effective flower for home decoration that can be had in the autumn. 10 each; $\$ 1.00$ per dozen.

Elva.-The most beautiful of white pompoms, pure in color of full, fluffy form; very early; extremely useful to every grower of cut flowers.

Inga.-Bright red of beautiful shade; elegant form; one of the earliest.

Klondike.-Most beautiful yellow in the family; extra fine. Lillian Doty.-Beautiful shell-pink, borne in great profusion.

\section{Rattlesnake Plant}

SANSAVERIE ZELANICA (RATTLESNAKE PLANT).Very hardy; for house culture; very attractive. 25c,50c and $\$ 1.00$ each.

\section{Cyclamen}

CYCLAMEN (Splendid Cyclamen for Winter Blooming). Flowers of extraordinary size, and of great substance. The leaves are proportionately large and beautifully marked. These are among the most beautiful winter and spring flowering plants for the window and greenhouse.

Not only are the flowers of striking beauty, but the foliage is highly ornamental. The colors range through shades of pink, crimson, white, spotted, etc. Most of them are, moreover, delicately fragrant. Fine large plants, $\$ 1.00$ and $\$ 2.00$ each. Ready to sell November 1st to April 1st only. Small plants with buds, 50c.

\section{Fuchias}

FUCHIAS.-We have no plant that can equal in grace these denizens of the forests of our southern hemisphere. Grow in a shady place in summer in soil composed largely of leaf mold or sandy loam. Grow in sunny window and turn frequently to the light. 25c each. Ready to sell February 15th to April 15th.

\section{Firecracker Plant}

FIRECRACKER PLANT (RUSSELIA JUNCEA).-It is a beauty; very valuable for basket and vases. 10 each.

\section{Bougainvillea}

BOUGAINVILLEA (SANDERIANA)-Most desirable plant for conservatory or window garden. They are of strong, rapid growth and produce their lovely, brilliant, rosy crimson flowers from early in March until mid-summer. With extra care and attention they will bloom the greater part of the year. 25c each; large plants, $50 \mathrm{c}$ and $\$ 1.00$ each.

\section{Cyprus Alternifolius}

CYPRUS ALTERNIFOLIUS (UMBRELLA PLANT).-A grass-like plant, throwing up stems to the height of about two feet, surmounted at the top by a cluster or a whorl of leaves, diverging horizontally, giving the plant a very curious appearance. A splendid plant for the center of baskets, vases or porch boxes, or as an aquarium plant. $15 \mathrm{c}, 25 \mathrm{c}$ and $50 \mathrm{c}$ each.

\section{Fiscus Elastica}

FISCUS ELASTICA (Rubber Tree).-Nothing better for table or house decoration. Its dark green shiny foliage is always handsome, and its constitution is such that it is able to stand the excessive heat and dryness of the ordinary dwelling house without injury. Nice large plants, by express, $75 \mathrm{c}, \$ 1.00$ and $\$ 2.00$ each.

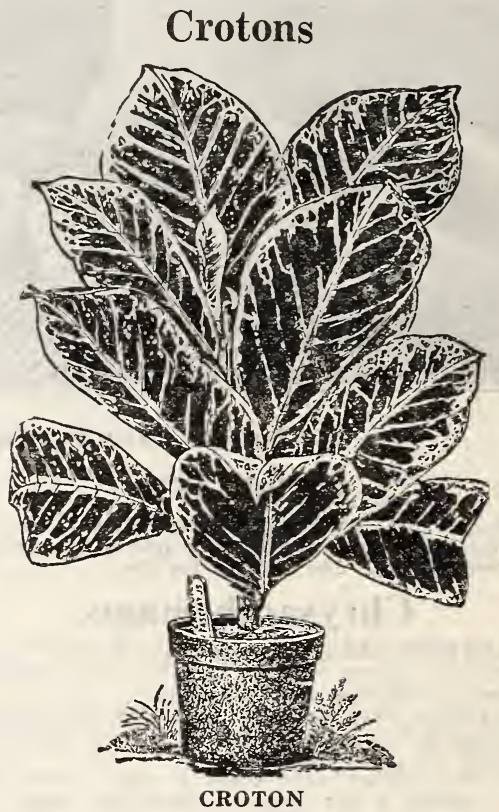

CROTONS.-A very handsome foliage plant, stards the sun better than any plant we know; is more ornamental than palm or fern, as it is always bright and pretty; either in pot or yard. Try one. 35c,50c, $\$ 1.00$ and $\$ 2.00$ each.

\section{Coleus}

COLEUS.-We have a splendid collection of this justly popular foliage plant, and can supply any color desired. We have not space here to name and describe them, but we have about twenty sorts to choose from, and all good ones, just the shades of color you desire, and we can please you in selection. We have all shades of red, yellow, purple, green and speckled, spotted and mottled, and we can supply any color or mixture of colors. Price for nice plants, 10c each; $\$ 1.00$ per dozen. Plant outdoors after April 1st.

\section{Coleus Christmas Gem}

COLEUS CHRISTMAS GEM-(BRILLIANCY) (DR. ROSS). Leaves immense, eight to twelve inches long. Cannot be 
excelled as a pot plant. The name aptly describes the appearance of this variety, which belongs to the giant-leaved section; of strong, vigorous habit. Leaves are of bright carmine, shading off to a deep maroon, the margin being yellow and green, the whole leaf having a rich velvety lustre. 15c and $25 \mathrm{c}$ each.

\section{Cigar Plant}

CIGAR PLANT (LADIES' CIGAR PLANT).-This is a wellknown ever-blooming plant of neat habit, growing about 12 inches in height. The tube of the flower is scarlet, with the end partly white and crimson; very useful as ribbon line or front border plant. $10 \mathrm{c}$ each; $\$ 1.00$ per dozen.

\section{Ferns}

Asparagus Sprengeri.-15c, 25c, 50c and $\$ 1.00$ each.

Boston Fern. - 15c, 25c, 50c, $\$ 1.00, \$ 2.00, \$ 3.00$ and $\$ 4.00$ each. Ostrich Plume Fern (Whitmanii).-15c, 25c, 50c, $\$ 1.00$ and $\$ 2.00$ each.

Compacta. $-25 c, 50 \mathrm{c}$ and $\$ 1.00$ each.

Scotti.-Dwarf Boston type. 25c, 50c, $\$ 1.00$ and $\$ 2.00$ each. Asparagus Plumosa.-15c, 25c, 50c and $\$ 1.00$ each. Adiantum Cunateum (Maiden Hair).-25c and 50c each. FERNS.-Ferns of all varieties to be had the year round. The small plants can only go by mail, but all should go by express; it gives you better and larger plants.

Neophrolepsis Bostoniensis (See cut). (Boston Fern).-The popularity that this plant has gained in the short time since introduction is simply marvelous. It is one of the finest decorative plants ever introduced. Grows rapidly under all conditions, and its inexpensiveness places it within the reach of everyone. Often called "Fountain Fern" on account of its gracefully drooping habit. Fully matured fronds often attain a length of four feet. Large plants, by express, $25 \mathrm{c}$, $50 \mathrm{c}$ and $\$ 1.00$.

Plumed Scotti Fern (Nephrolepsis Scholzeli).-The ideal plumed Fern, holding the same position to all other plumed varieties that Scotti holds to the old Boston. It is a sport from Scotti, possessing all of the merits of that most popular variety, but with the pinnate subdivided, giving it an airy, feathery appearance. Nicely shaped plants, large size, 50c, 75c and $\$ 1.00$ each.

Adiantum Cuneatum (Maidenhair Fern).--Very popular; the most graceful and useful in cut-flower work. $25 \mathrm{c}$ and $50 \mathrm{c}$ each.

Neph. Whitmanii.-The finest all-cut leaves of the Nephrolepsis variety to date. Plants rare and costly, but they are so rare and dainty that you will not regret having bought at least a small plant. 25c, 50c and $\$ 1.00$ each.

Nephrolepsis Cordata Compacta.-A dwarf, compact growing form of Sword Fern. Making sharply pointed plants 2 feet high when fully matured. Its deep green fronds have just enough arch to make them graceful. 25c,50c and $\$ 1.00$ each.

Roosevelt Fern.-The grandest Fern of its class yet introduced. It resembles the world-famous Boston Fern, but produces twice as many wide, drooping fronds, and the pinnates are beautifully undulated, giving it a pronounced wavy effect seen in no other variety. It has sprung into wonderful popularity, and when bettex known will be wanted by everyone. 25c, 50c and $\$ 1.00$ each.

"Teddy Junior."-It is a sport from the now famous Roosevelt Fern. The fronds have an attractive wavy appearance, which adds materially to their charming decorative effect. "Teddy" will produce about four times more fronds than any other Fern. It is a compact, vigorous grower, will thrive under most adverse conditions, making an exceptionally rapid growth and producing a plant of rare beauty and perfection without special care or attention. Finest pedestal plant produced. Fine young plants, $25 \mathrm{c}$ each; larger size, 50c and $\$ 1.00$ each.

\section{ASPARAGUS FERNS.}

Plumosus Nanus.-A beautiful climbing plant, with bright green, graceful arched foliage, surpassing Maidenhair Fern in grace, delicacy of texture and richness of color. The fronds are 12 to 15 inches long and taper to a point from a width of 12 inches. One of the most beautiful decorative plants. Nice plants, $15 \mathrm{c}$ and $25 \mathrm{c}^{\prime}$ each; large size, 50c and $\$ 1.00$ each.

Sprengeri-Especially useful to grow as a pot plant for decorative purposes, for planting in ferneries or suspended in baskets. It grows freely the whole year and makes an excellent house plant. A vigorous grower, producing sprays
4 to 5 feet long of fresh green, feathery foliage. Useful for bouquets, wreaths or sprays, remaining perfect for weeks after cutting. Strong plants, $15 \mathrm{c}$ and $25 \mathrm{c}$ each; large, 50c to $\$ 1.50$ each. (See cut).

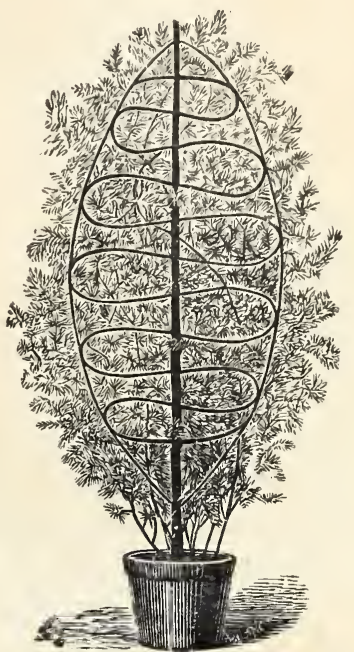

asparagus plumosus

\section{Pansies}

PANSIES.-As we have given this plant special selection and cultivation, the stock offered can be relied on as embracing the best from foreign and domestic collections. It combines with the flowers of the largest and finest form the most exquisite graduations of color. Large plants in bloom, $10 \mathrm{c}$ each, $\$ 1.00$ per dozen; $\$ 6.00$ per 100 ; planting size, $50 c$ per dozen, $\$ 3.00$ per 100 . Ready from November April 15th.

\section{Poinsettia}

POINSETTIA.-The Christmas plant, unexcelled for pot plant: hardy in the southern states. The plant grows to a height of 3 to 5 feet and makes an immense head of brightest red leaves, which is the flower, and makes it the show flower for Christmas decorations. Flowers will last four to eight weeks. Large plants, 50c, nice plants, 25c. Spring delivery only.

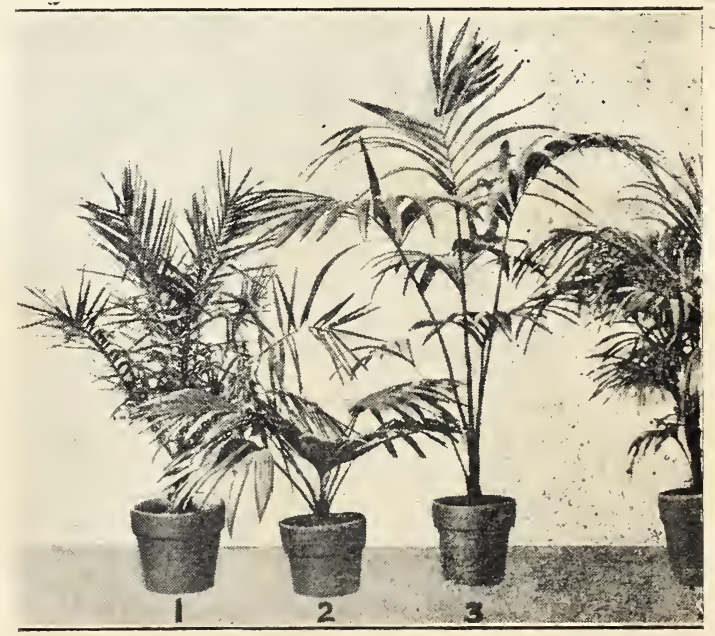

PALMS 
LANG FLORAL AND NURSERY CO., DALLAS, TEX.

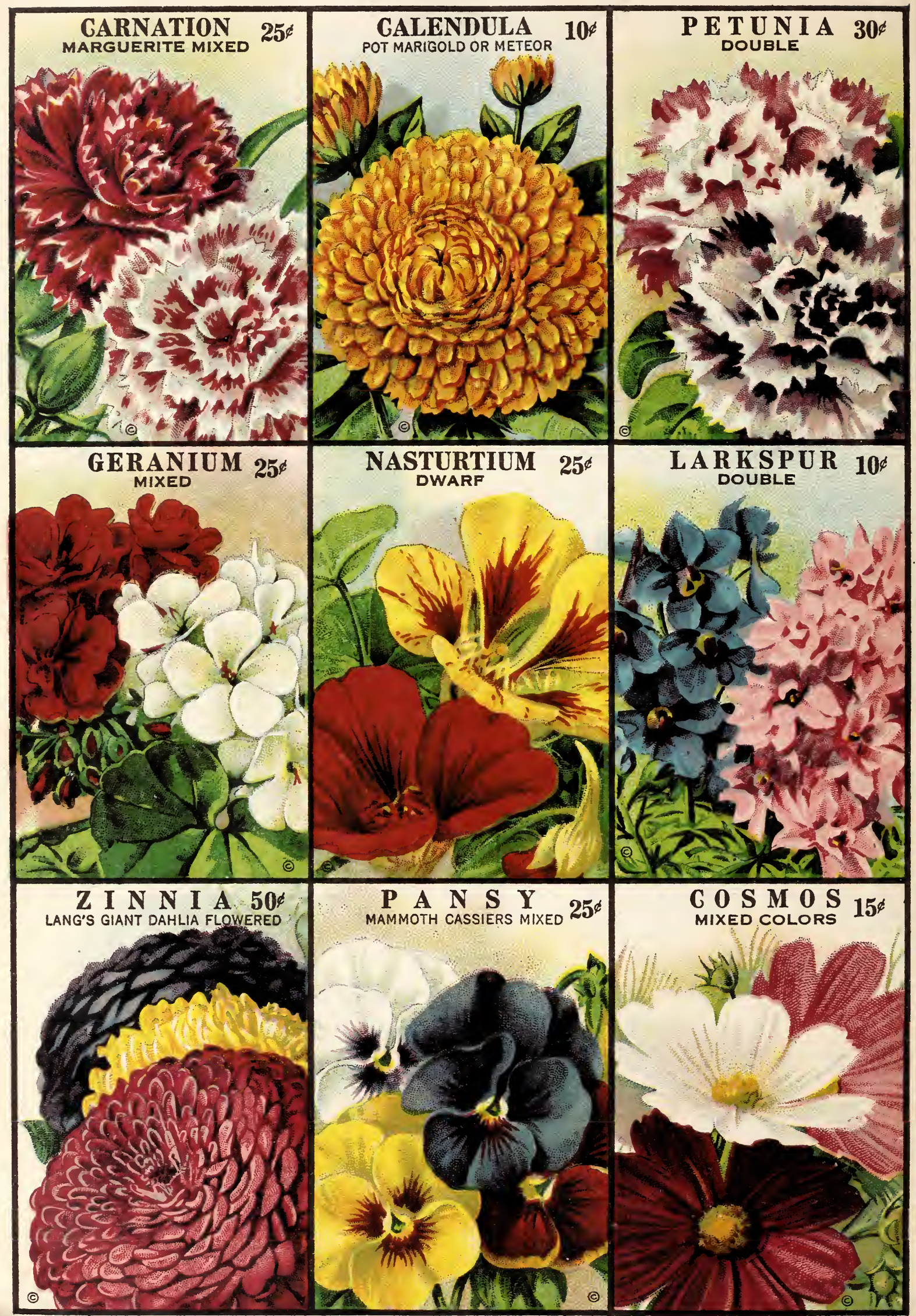




\section{LA N D S A P I N G}

\section{High Class Evergreens}

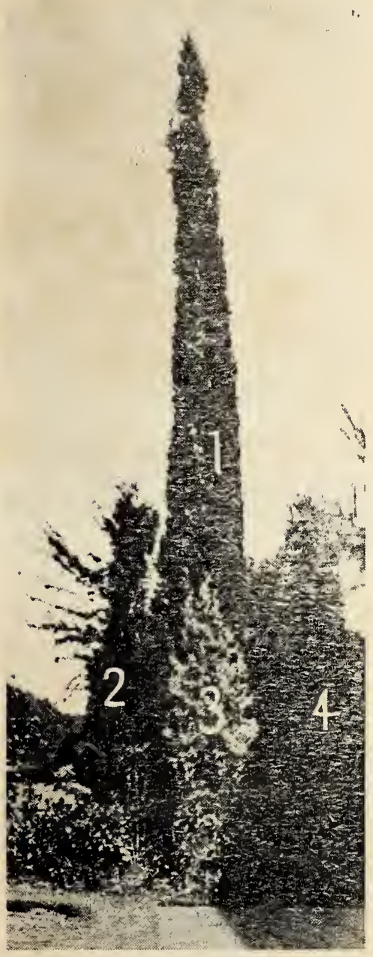

For immediate show on large home grounds this planting will be your best investment. Don't put it off-plant now.

No. 1, ITALIAN CYPRESS - The most artistic growing tall evergreen.

No. 2, AMERICAN ARBORVITAE-Fast growth, beautiful color.

No. 3, SILVER CEDAR-Tall, graceful growth of silver blue shade. Price, $\$ 2.00$ per foot in height.

No. 4, PYRAMIDAL ARBORVITAE-Fine for massing or single plants. Price, $\$ 2.00$ per foot in height, balled in soil. For description and price of Nos. 1 and 2, sea Ornamental Evergreen, pages 19 and 20.

ARIZONA CYPRESS - Handsome pyramidal plants, $\$ 1.50$ and $\$ 2.00$ per foot in height on heavy stock. For light grade use see Ornamental Evergreen, page 20.

CEDRUS DEODORA-There is no evergreen for single or specimen plants grown that can surpass this in beauty. Price, $\$ 2.00$ per foot in height for balled plants.

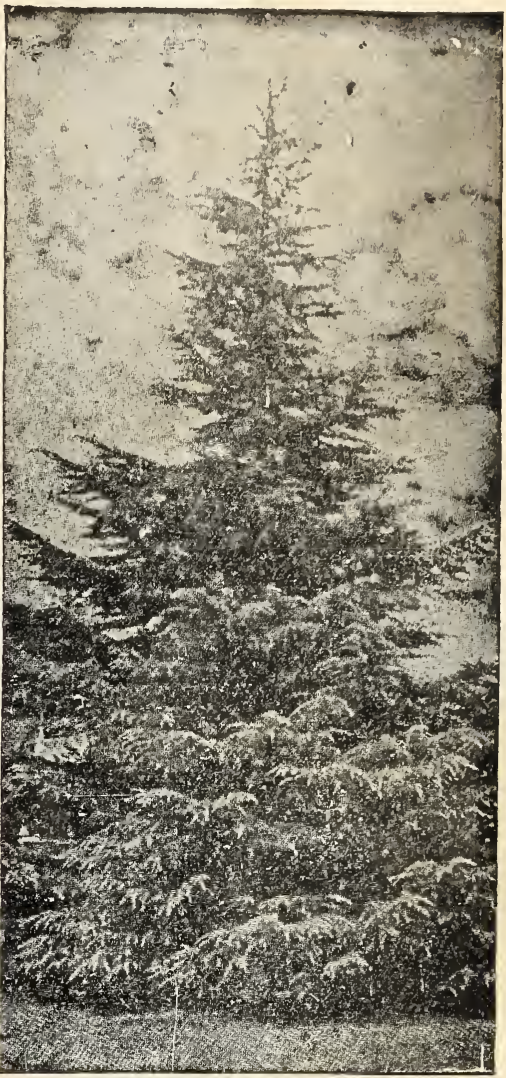

CEURUS DEUUURA

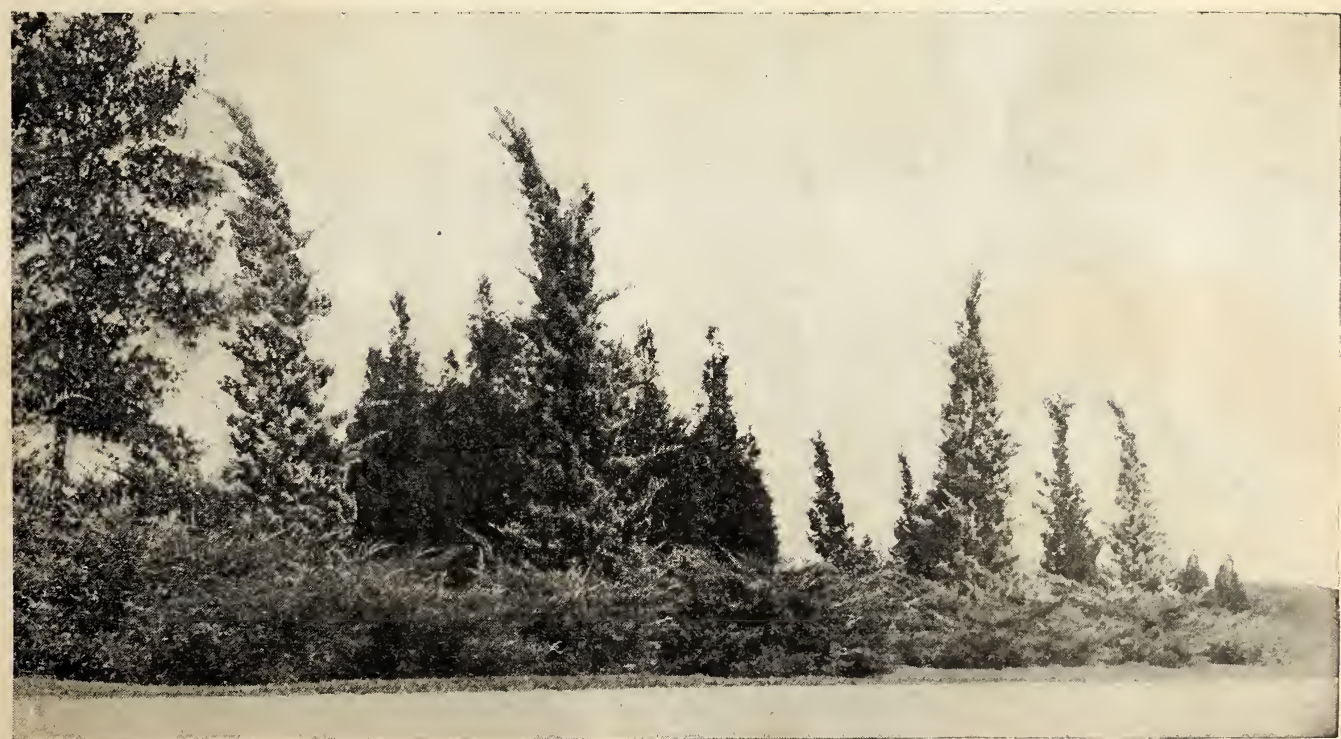

The tall Cedars are Virginia Glauca. Sizes 3 to 10 feet high. $\$ 2.00$ per foot in height. The border is Pfitzer Juniper$\$ 1.50$ per foot spread. 
SELECTED VEGETABLE SEEDS OFFERED BY THE

LANG FLORAL and NURSERY CO., DALLAS, TEX.

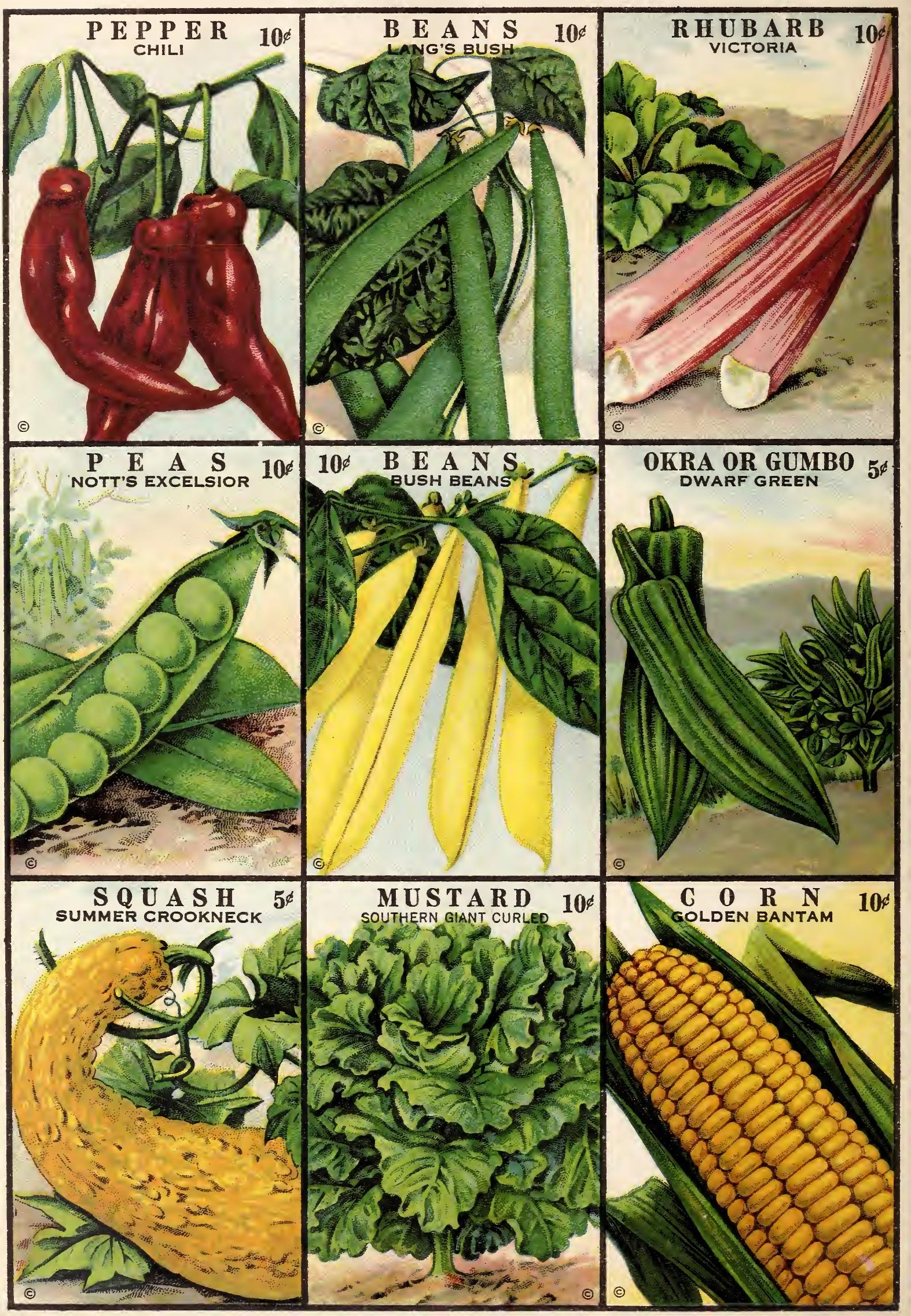


SELECTED VEGETABLE SEEDS OFFERED BY THE

LANG FLORAL and NURSERY CO., DALLAS, TEX.

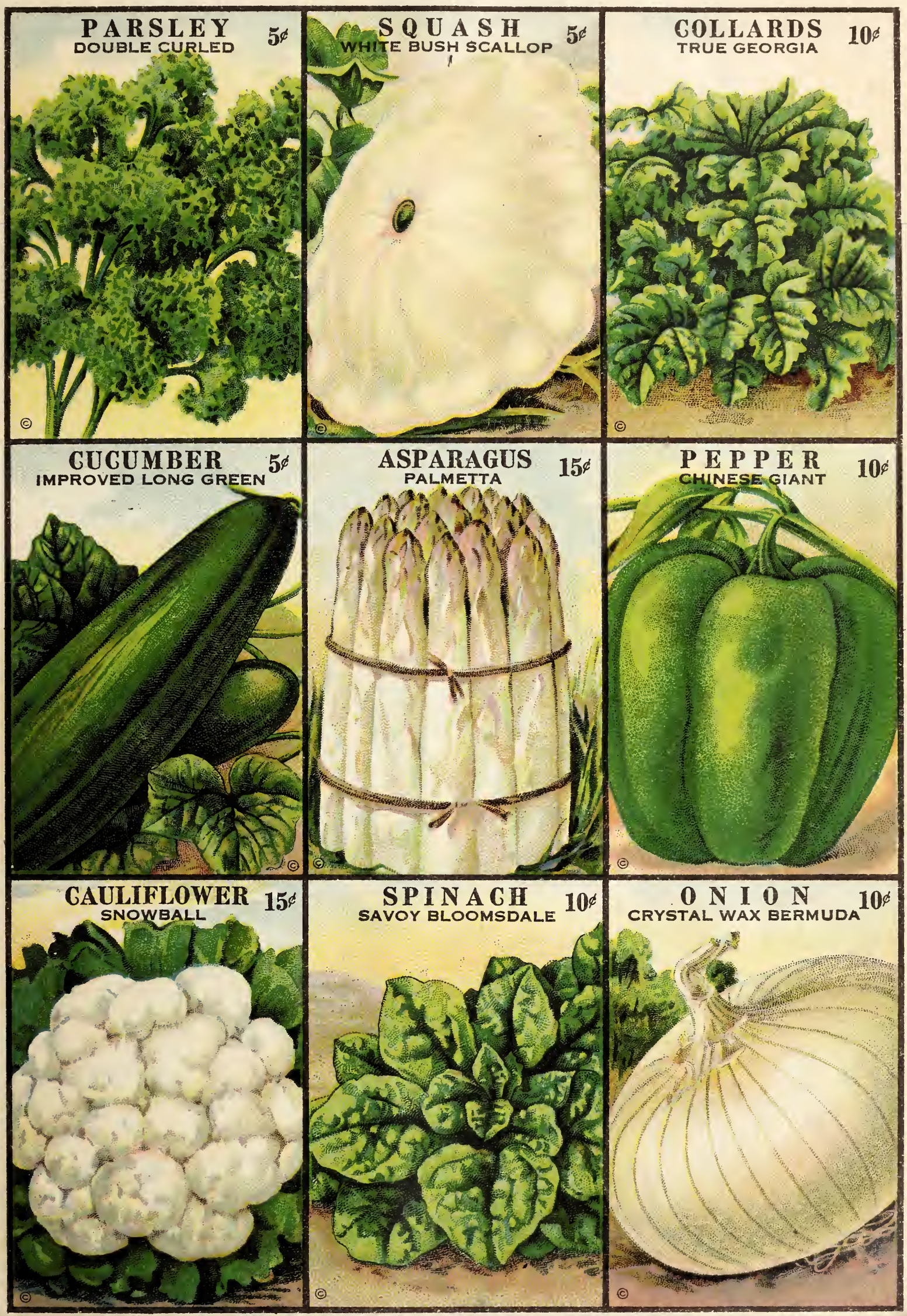




\section{STREET PLANTING}

\section{CHINESE ELM TREES}

This block of Chinese Elm was planted from small 1-year stock two years ago. The trees are now 3 years old and have been admired by several hundred thousand people in this short time. The Chinese Elm is a new tree and has been tested in the dry, arid parts of West Texas, South Texas, Oklahoma, Colorado, and other States, and found to stand the dry climate better than where it had plenty of water and cultivation. The tree will stand pruning to shape as you desire; the leaves are small, dark green, and stay on much longer than any trees in the Fall. In order to put it in reach of all we are making the following low prices:
5- 6 feet
$\$ 1.00$ each
6- 7 feet
1.50 each
7- 8 feet
2.50 each
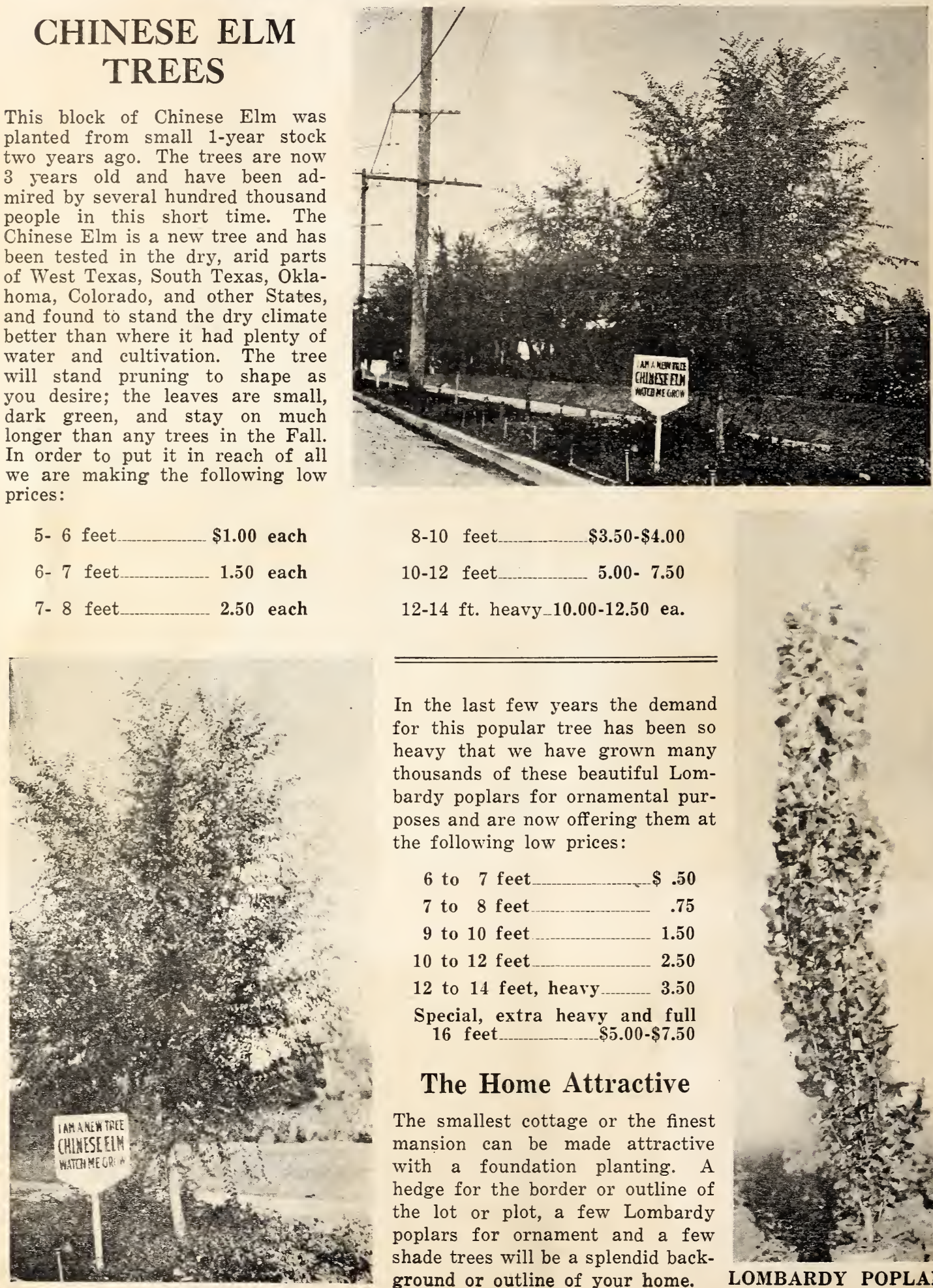

8-10 feet

$\$ 3.50-\$ 4.00$

10-12 feet

$5.00-7.50$

12-14 ft. heavy_10.00-12.50 ea.

In the last few years the demand for this popular tree has been so heavy that we have grown many thousands of these beautiful Lombardy poplars for ornamental purposes and are now offering them at the following low prices:

$\begin{array}{rr}6 \text { to } 7 \text { feet } & .50 \\ 7 \text { to } 8 \text { feet } & .75 \\ 9 \text { to } 10 \text { feet } & 1.50 \\ 10 \text { to } 12 \text { feet } & 2.50 \\ 12 \text { to } 14 \text { feet, heavy } & 3.50 \\ \text { Special, extra heavy and full } \\ 16 \text { feet } \$ 5.00-\$ 7.50\end{array}$

\section{The Home Attractive}

The smallest cottage or the finest manșion can be made attractive with a foundation planting. A hedge for the border or outline of the lot or plot, a few Lombardy poplars for ornament and a few shade trees will be a splendid background or outline of your home.

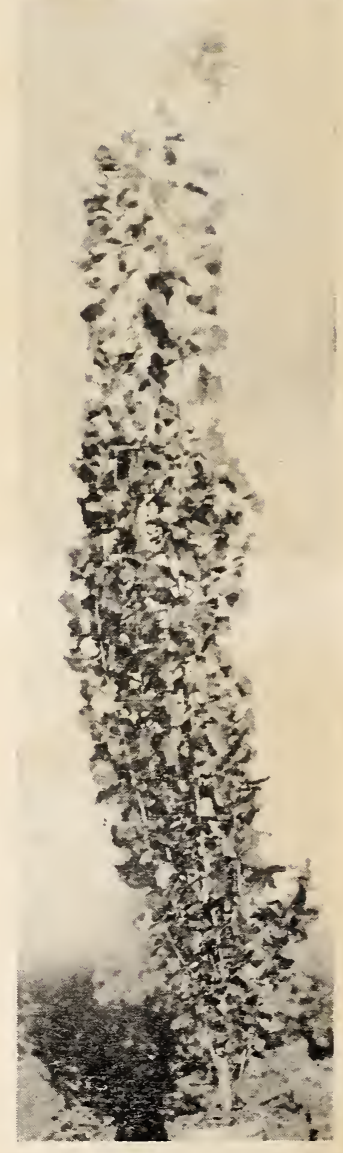

LOMBARDY POPLAR 
LANG FLORAL aNd NURSERY CO., DALLAS, TEX.

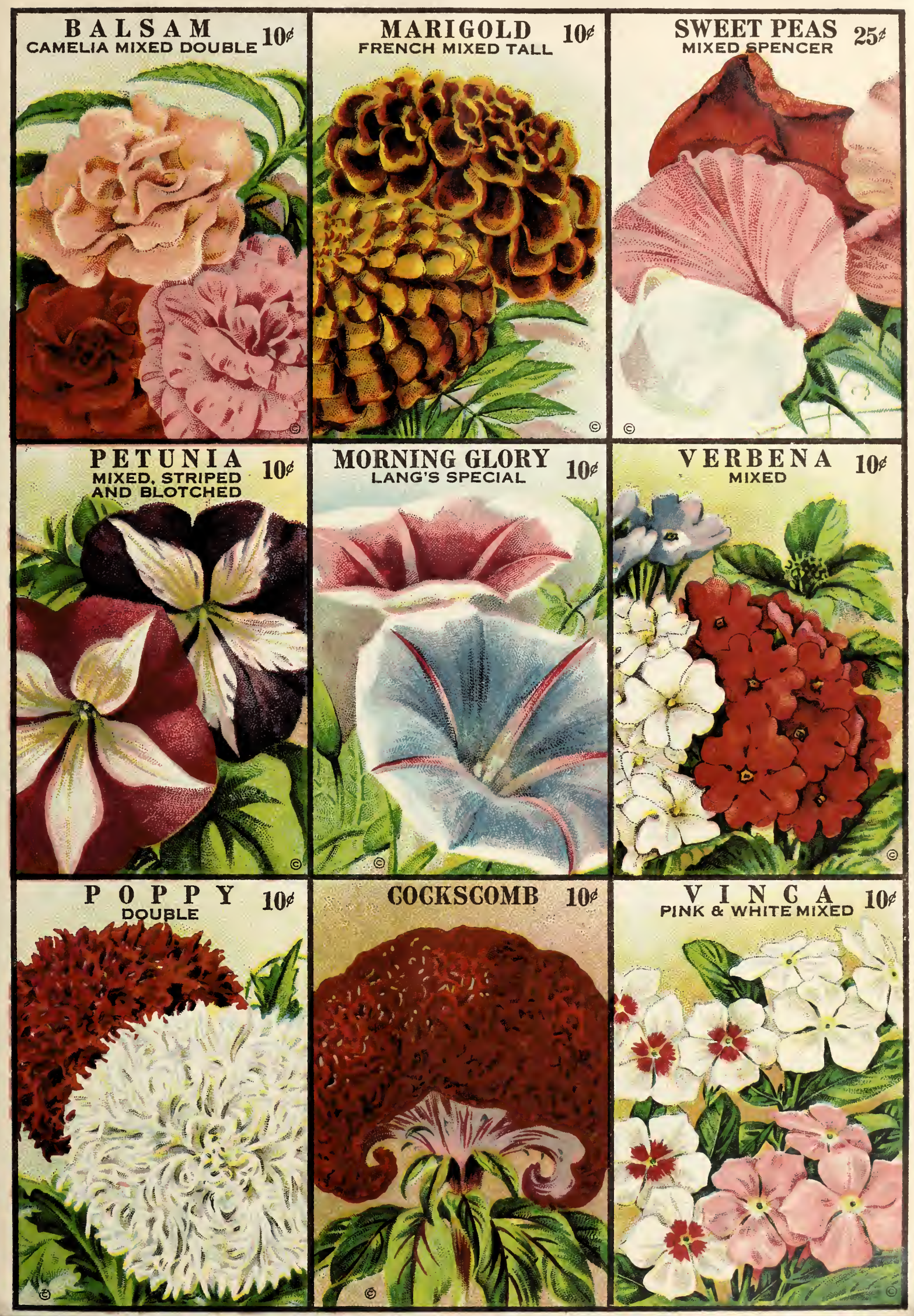




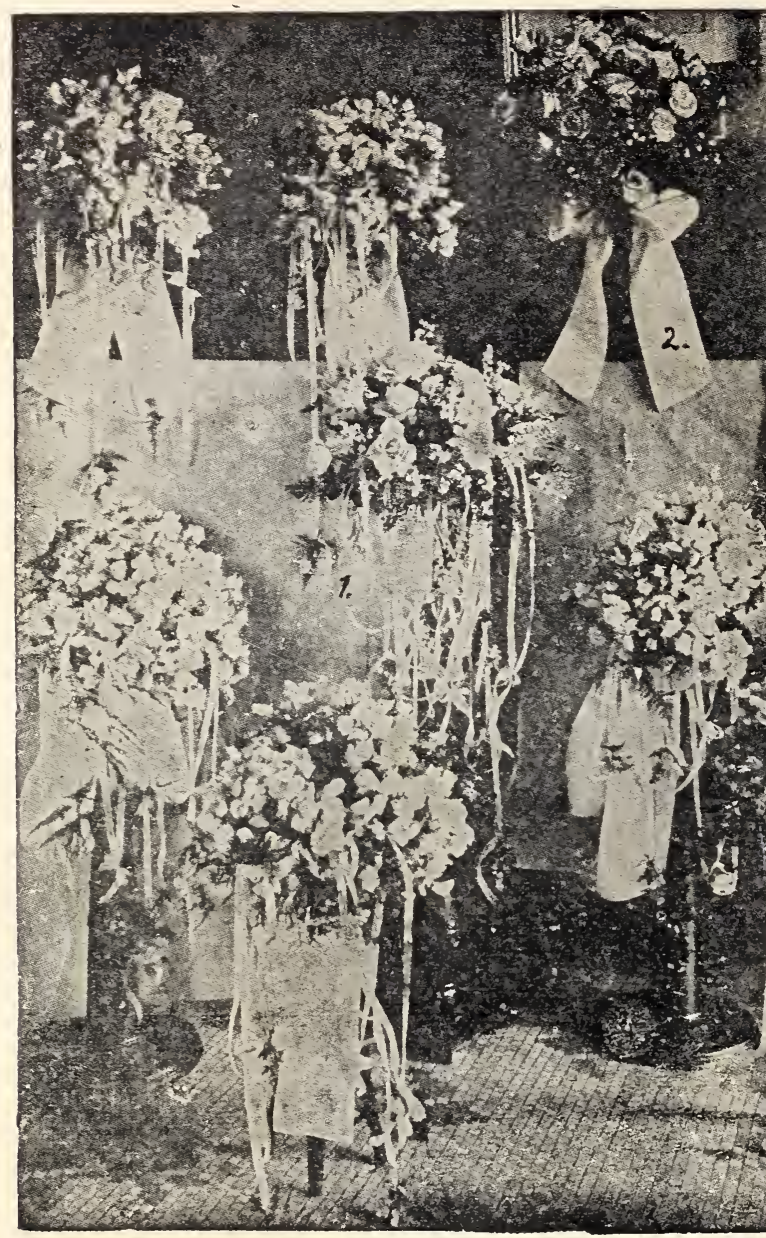

Bouquets for the Bride and Her Attendants

Various Bouquets for a Bridal Party

No. 1.-Shower Bouquet of Roses and Lilies of the Valley for the bride, consisting of $2 \frac{1}{2}$ dozen Bride's Roses, 50 Lilies of the Valley and 15 yards of small shower ribbon, with 3 yards fancy chiffon, total cost, \$17.50.

Same with less Valley and shower, \$12.50. Roses and ribbon only, no shower, $\$ 6.50$. All Lilies of the Valley Shower, $\$ 15.00$; Lilies of the Valley and Orchids Shower, $\$ 17.50$ to $\$ 25.00$.

No. 2.-Maid of Honor Bouquet; Bride's or Bridesmaid Roses and 3 yards chiffon ribbon. Cost $\$ 6.00$. Same can be made of Easter Lilies, Carnations and other flowers in season. The other two illustrations were made for the Bridesmaids, of Sweet Peas in Shower style at a cost of $\$ 6.00$ each.

Same can be made of Carnations, white or pink Roses, in shower style, from $\$ 7.50$ to $\$ 10.00$ each, or without shower and tied with nice Chiffon, from $\$ 4.50$ to $\$ 7.50$.

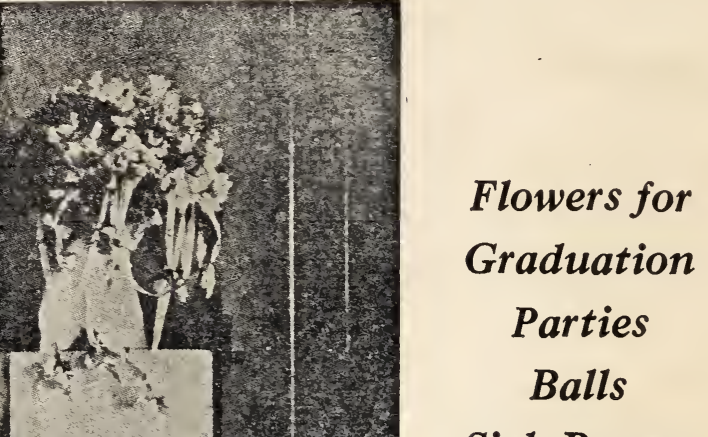

Sick Rooms

Gifts 


\section{HOUSE AND YARD PLANTS}

(Continued From Page 25.)

\section{Palms}

PALMS.-All Palms in pots 4-inch or over should come by express at purchaser's expense; if wanted by parcel post please add 15 per cent of the cost of plants.
plased

We are making a specialty of Palms and have one of the largest and best stocks of them to be found anywhere.

The Kentias are recommended as being the hardiest and best for house culture, as dust and gas does not affect them as much as many other palms. Where height of plant is given it means height from top of pot.
All Palms may be had the year round, nice plants, $50 \mathrm{c}$ each; large plants, 18 to 20 inches high, $\$ 1.50$ to $\$ 3.00$.

No. 1. Phoenix Canarensis. - The most satisfactory palm for the house, porch or lawn. Grows to be very large. $50 c, \$ 1.00, \$ 2.50, \$ 3.50$ and $\$ 5.00$

No. 2. Latania Borbonica-Fan Palm.-A beautiful palm, with large, deeply divided fan-shaped leaves; it is easy of cultivation and should be in every collection

No. 3. Kentia Fosteriana.-Much like Balmoreana, except that it grows taller, with larger, heavier foliage. Same price as Kentia Balmoreana, only taller.

No. 4. Phoenix Roebelenii.-The most graceful of the Phoenix, and a Palm which has become one of the popular for room decoration. The plant is of growth, and its gracefully recurving leaves, with very narrow dark green pinnae, give it a lightness and airiness

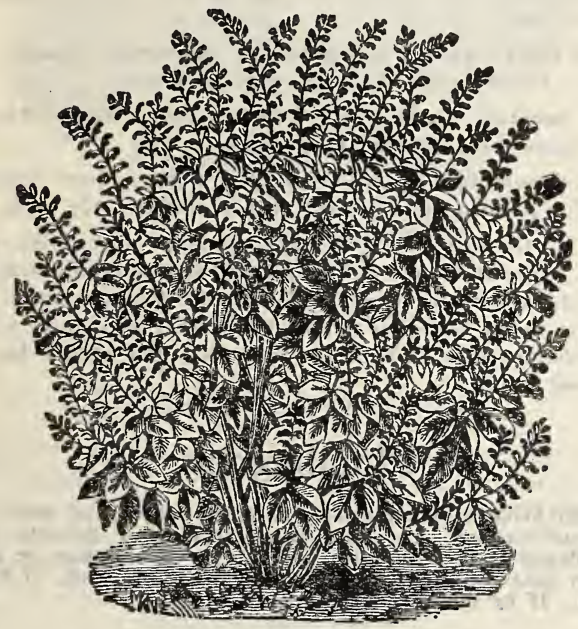

SALVIA SPLENDENS

\section{Violets, Texas}

VIOLETS-TEXAS. - The Texas violet is of a darker purple than the California, not quite as long stems, but by far a better bloomer and withstands the hot trys, summer better than any violet we have ever grown. Large plants, 10c each: $75 \mathrm{c}$ per dozen. Ready for sale or planting November 15th to April 15th. If wanted by mail, add $10 \mathrm{c}$ per dozen.

\section{Hydrangea Otaska}

HYDRANGEA OTASKA.-A Japanese variety producing immense heads of pink flowers. This is the variety imtensively used for Easter decorations. Plants, 25c, 75c and $\$ 1.00$. On sale November 15th to May 1st. By mail, 5c extra for small plants; add $10 \mathrm{c}$ extra for large plants.

\section{Periwinkle or Vinca}

PERIWINKLE OR VINCA.-This is a most pleasing and attractive shrub plant, blooming the entire summer season, forming a handsome shrub two feet in height and diameter. Color-rose, white and white with crimson center. 10c each; $75 \mathrm{c}$ per dozen.

\section{Heliotropes}

HELIOTROPES.-All fine sorts, fragrant, blue, lavender and white, at $10 \mathrm{c}$ each; $\$ 1.00$ per dozen. Ready to sell December 1 st to May 1st. If wanted by mail, add $15 \mathrm{c}$ per dozen.

\section{Verbenas}

VERBENAS.-One of our specialties. This list we offer cannot be excelled. No garden is complete without a collection of Verberas. Red, pink, purple, white. Don't i collection some Verbenas. 10c each, 75c per dozen. Ready February 1 st to May 15th. By mail, add 10c per dozen.

Beauty of Oxford.-Extra large vigorous grower, cerise-pink. A real knockout. 15c each, $\$ 1.50$ per dozen. By mail, 10c

\section{Verbena, Lemon}

VERBENA-LEMON.-Or Sweet Verbena, is a favorite on account of its lemon-scented foliage and lilac-scented flowers. Each, $15 \mathrm{c}$ and $25 \mathrm{c}$. Ready to sell December 1st to May 1st;

\section{Geraniums}

GERANIUMS.-We grow over 100,000 Geranium plants, shipping them over many states-No better or finer stock or variety can be found anywhere. Try a few. Small size named varieties, $15 \mathrm{c}$ each, $\$ 1.50$ per dozen; larger size, $25 \mathrm{c}$ and $35 \mathrm{c}$ each, $\$ 2.50$ and $\$ 3.50$ per dozen. Unnamed varieties $10 \mathrm{c}$ each, $\$ 1.00$ per dozen; larger plants, $25 \mathrm{c}$ each, $\$ 2.50$ per dozen.

\section{DOUBLE.}

S. A. Nutt.-The very best of the dark crimson scarlet bedders. Always in heavy demand. We have a very large stock of it. Stands the sun perfectly, and is always a mass of blooms.

Ruby.-Seedling of S. A. Nutt and Pamela. Beautiful semidouble clusters on long stems. Both florets and clusters are much larger than S. A. Nutt. Color dark currant red suffused with violet. We consider this the best dark red we grow and think when better known it will supersede S. A. Nutt.

Alphonse Ricard.-Large semi-double flowers, often measuring two inches in diameter, borne in enormous trusses, on long flower stems. Continues in bloom the entire season.

Jean Viaud.-Large, semi-double rosy-pink flowers with white eye. Blooms with uninterrupted freedom the entire season, and is of such rapid and vigorous habit of growth that it makes one of the best all-round plants obtainable.

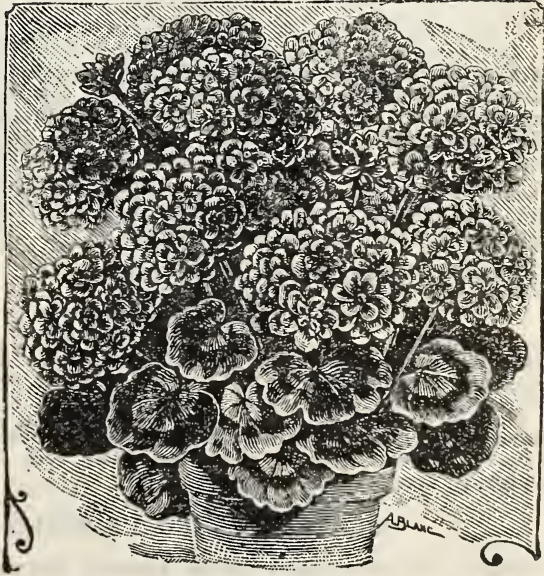

Joan Viaud. 
La Favorite-Trusses very large, florets of the most beautiful and perfect form, and of the very purest, snowiest white in color.

Beaute Poitevine.-The best semi-double, salmon bedder, large flowers, aurora-pink shading to bright salmon.

Red Wing.-Deep cardinal red, with a soft velvety sheen unusually attractive; semi-double flower, of good substance: large trusses as free as S. A. Nutt in bloom. Plant is strong growth and makes an ideal pot plant or bedder, as it stands the sun well; has no rival in its color.

American Beauty.-Distinct low-branching, short-jointed growth and dark, crimpled foliage. Color rich American Beauty shade. Very beautiful; fine bloomer.

Spaulding Pet.-This is a profuse bloomer with large bright scarlet flowers, semi-double, and has the remarkable faculty of blooming right through the hottest and dryest weather is also a luxuriant grower. This is a variety that is especially desirable for the South.

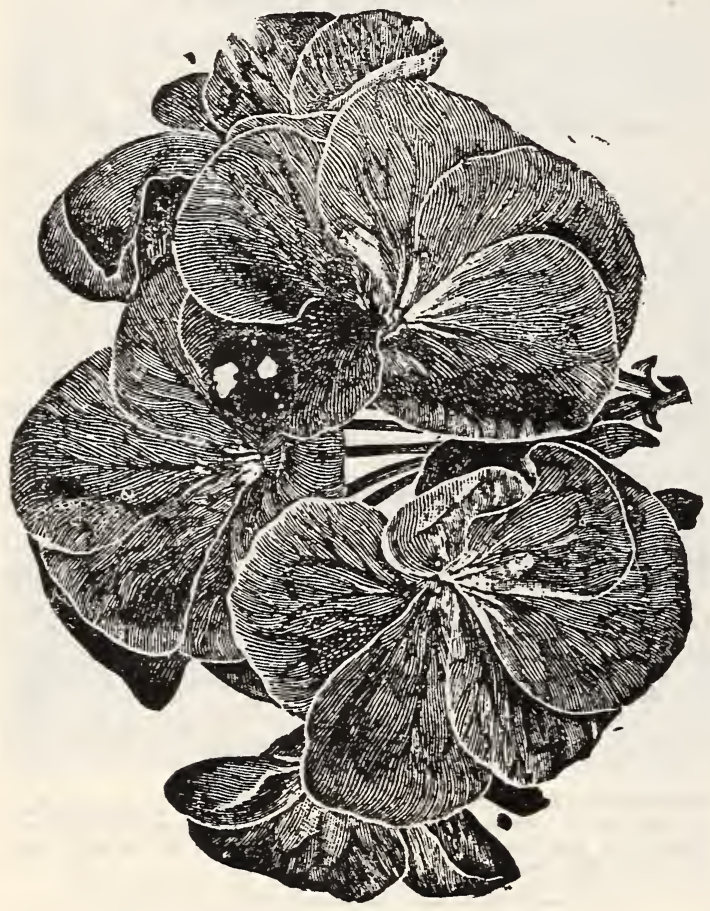

E. G. HILI

\section{SINGLE}

Mrs. E. G. Hill.-A magnificent variety; enormous trusses of large florets; the center of each petal is a soft light salmon bordered with rosy salmon; habit exceptionally strong and vigorous: attractively zoned; semi-dwarf; stands the sun perfectly. An old favorite bedder and pot variety.

Jacquerie.-A most beautiful shade of deep carmine-red; immense trusses on exceptionally long stems; very vigorous grower and unsurpassed as a bedder.

Granville.-Large, soft, clear pink.

\section{IVY LEAVED GERANIUM}

Caesar Franck.-Trusses very large, florets immense and very regular form, quite full; the color is an exquisite shade of rosy carmine. $15 \mathrm{c}$ each.

Roycroft's Surprise.-One of the most beautiful Ivies we have. In color it is a charming clear rose of rich pink, which is very attractive. $15 \mathrm{c}$.

\section{SCENTED LEAVED VARIETIES}

Nutmeg.-Dwarf, bright green foliage; nutmeg fragrance. $10 \mathrm{c}$ each.
Rose.-A skeleton leaved, strongly rose-scented with finely cut foliage. Often used for flavoring jellies, etc. $15 \mathrm{c}$ and $25 \mathrm{c}$ each.

Apple.-This grand old favorite fills a room with its delicious apple blossom odor. 25c each.

PELARGONIUMS (Easter Greeting). -The earliest of all Pelargoniums with enormous florets and clusters having light green foliage and of dwarf robust growth. It blooms from March until fall. The florets are of a fiery amaranth red with five regular shaped spots. The first and only kind to do so all summer. $15 \mathrm{c}, 25 \mathrm{c}, 50 \mathrm{c}$ and $\$ 1.00$ each.

\section{Jasminum}

JASMINUM.-The sweetest flower grown. Be sure to try one of each'.

Grand Duke.-Large; double, white, imbricated flowers ; fragrant. 15c and 25c. Fine for pots in house.

Cape Jasmine.-Delightfully fragrant; pure white. 25c and 50c; large yard plants, $\$ 1.00$ each.

Night Blooming.-Blooms at night; flowers very fragrant. Fine for planting in the yard; rapid grower. $15 \mathrm{c}$ each.

Maid of Orleans.-A very attractive new sort, with goodsized, semi-double flowers, blooming profusely all summer shining pale green foliage. We predict for it a rapid sale, as it is much easier to handle than other Jasmines, and as a whole, more desirable. 15c and 25c. Pot plants for sale the year round.

\section{Plumbagoes}

PLUMBAGOES (Capiensis).-A plant worthy of more general cultivation; producing large trusses of delicate azure blue flowers. Excellent for bedding out in summer or growing in pots for single specimen plants. 15c each, $\$ 1.50$ per dozen. If by mail, add $10 \mathrm{c}$ per dozen.

\section{Lantana}

\section{LANTANAS ARE THE BEDDING PLANTS FOR THE SOUTHWEST}

LANTANAS.-This splendid bedding plant is increasing in popularity because of its splendid blooming habit and remarkable drought-resisting qualities. Plant them April Ist to Aust 1st. They are in bloom all summer and with little covering of straw over the roots during the winter little covering of straw over the roots during the winter
they usually come up the following spring. Price, 10c each, $\$ 1.00$ per dozen. By mail, 15c extra per dozen.

We have the following named varieties:

A. Cook.-Dwarf, orange-yellow, changing to bright rose. Michael Schmidt.-Dwarf. Red, orange and yellow, very popular.

Radiation.-Medium height. Orange-yellow, changing to brilliant red. A good bloomer.

Violet King.-Medium height. Opens yellow and gold, changing to an intense purplish red.

Jacob Schultz.-Tall. Yellowish-orange, turning to an intense red.

\section{Lantanas, Weeping}

LANTANAS-WEEPING.-A grand plant for baskets and vases. May be used to good advantage in connection with other plants, but is more effective when used alone, where its bright colored bloom forms a perfect mound of flowers. A fine plant for winter flowering in the house pots or small hanging baskets. Flowers delicate rosy lilac, borne freely all over the plant from the base of each leaf stalk. $10 \mathrm{c} \mathrm{each,}$ 3 for 25c. Ready November 15th to June 1st. 


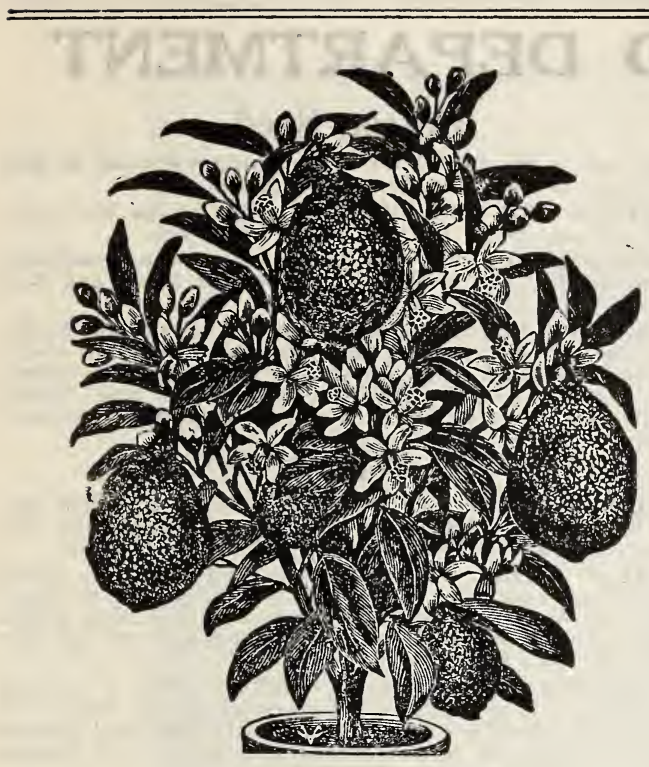

PONDEROSA LEMON

\section{Lemon, Ponderosa}

LEMON-PONDEROSA.-One of the best selling plants : grows rapidly and forms nice, bushy plants; blooms and bears fruit freely at the same time. Nice plants, 25c: large plants, 50c, 75c and $\$ 1.00$. Plants on sale the year round. By express only; the small size can be shipped by mail.

\section{Mint Plants}

MINT PLANTS.-A few plants will supply your requirements for this often needed herb for years to come, as it comes up every year. Good plants, $10 \mathrm{c}$ each; $\$ 1.00$ per dozen.

\section{Moon Flower Vines}

MOON FLOWER VINES.-Ready to sell March 1st to May 15 th.

White.-So called from its rare peculiarity of blooming best at night, although it also expands its flowers on dull days. They are pure white, 5 or 6 inches across, emitting a rich Jasmine-like odor. 10c each.

Blue.-Intense violet blue, with reddish purple rays, 6 inches across. It blooms in the morning and on cloudy days. 10c each.

\section{Oleander}

OLEANDER.-The plants of the South, almost hardy in the northern parts of Texas. Grows to a height of 10 feet; a beautiful pot or tub plant for lawn; blooms nearly all season; very decorative. Colors-white, salmon, pink. Nice plants, 25c each; large plants, $50 \mathrm{c}$ and $\$ 1.00$ each.

\section{Vinca Major Variegata}

VINCA MAJOR VARIEGATA.-Pleasant and refreshing. This is a beautiful variegated trailing vine admirably adapted for hanging baskets and vases. The leaves are a glossy green, broadly margined a creamy-white, flowers blue. More Vincas are employed in vase and basket work than all other vines combined. $10 \mathrm{c}$ each, 3 for $25 c_{\text {s }} \$ 1.00$ per dozen.

\section{Hibiscus}

HIBISCUS.-Stands our hot, dry summers to perfection. 15c each; $\$ 1.50$ per dozen. Large plants, 25c and 50c. If wanted by mail, add $15 \mathrm{c}$ per dozen.

Peachblow.-One of the finest plant novelties of recent years. Flowers double, of a rich shade of clear pink, with small, deep crimson center; an entirely new variety.

Grandiflora.-Rich, glossy foliage, blooming profusely during the summer, literally covering the plant with scarlet crimson flowers.

Rubra.-Flowers enormous, double, clear red, tinted with violet; an unusually free bloomer. Plant outdoors after frost is over. Ready February 1st to May 1st.

\section{Primula Obconica}

PRIMULA OBCONICA.-A favorite pot plant for house and conservatory culture on account of its wonderful blooming qualities, flowering neariy all the year through. 50c each. Ready for sale October 15th to March 15th only. If my mail, add 5 cents extra.

\section{Sage Plants}

SAGE PLANTS.-Have fresh and dried sage when you need it; greatly used for seasoning sausage, dressings, etc. Strong plants, $25 \mathrm{c}$ each.

\section{Salvia}

SALVIA (Salvia Splendens).-The well-known Scarlet Sage. Another splendid flowering plant, with its plumes of dazzling scarlet flowers. Each, 10c; 75c per dozen; $8 \mathrm{c}$ per dozen for postage.

Dwarf Ever-Blooming Salvia Zurich.-A fine scarlet; very dwarf, an ever-bloomer, $10 \mathrm{c}$ each, 75c per dozen. Postage $8 c$ per dozen.

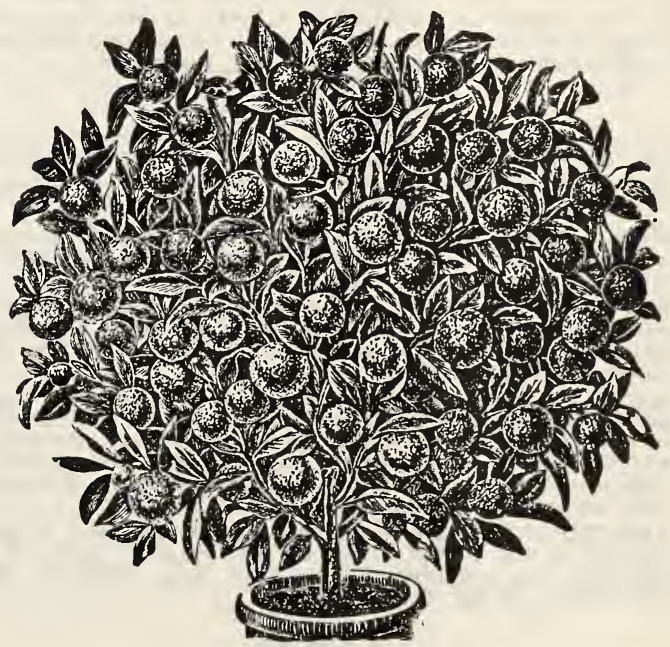

OTAHEITE ORANGE

\section{Otaheite Orange}

OTAHEITE ORANGE.-The best orange for pot culture. Plants dwarf and symmetrical in form. Flowers freely with a delightful orange fragrance. Fruit edible; about half the size of ordinary oranges. A grand plant for winter culture : scarcely ever without some display of blossoms or fruit. Nice plants, 25c; larger plants, 50c, 75c and $\$ 1.00$ each. Ready to sell the year round. 


\section{LANG'S FIELD SEED DEPARTMENT}

\section{PRICES ON FIELD SEEDS}

Up to and including 2 pounds all prices are prepaid; over 2 pounds to go by express or freight at purchaser's expense, unless otherwise stated.

Owing to the fact that this catalogue has to be in the hands of the printer in November and the market having not been established on many field seeds, we kindly ask our customers to write for prices on larger quantities. All prices quoted are subject to market changes without notice.

Any open order entrusted to us will receive all the money will buy at the current market price.

\section{NON-WARRANTY CLAUSE}

While we exercise all care to have all seeds pure and reliable we give no warranty, expressed or implied, as to description, quality, productiveness or any other matter of any seeds, bulbs or plants we send out and will not be responsible for the crop. If the purchaser does not accept these goods on these terms they are at once to be returned to us and the money paid for them will be refunded. Crops are dependent on so many other things besides seed that it is impossible for us to give any guarantee.

\section{Alfalfa}

MEDICAGO-SATAVA.-As a general rule good corn ground is good ground for alfalfa. In can in most cases be grown profitably on any land on which corn is suecessfully grown to a maturity. Price, 60c per pound; $10 \mathrm{lbs} ., \$ 5.00$.

\section{Broom Corn}

MPROVED EVERGREEN.-Grows about 8 to 10 feet high. Stands up well and is entirely free from crooked brush. Lb., 25 c

DWARF.-Grows 4 to 5 feet high and makes straw of finest quality. Lb., 25c.

\section{Cane Seed}

AMBER CANE.-Grown mostly for hay, Lb., 25c

EARLY ORANGE CANE.-Grown for hay and molasses. Lb., 25c.

RED TOP or SUMAC.-Grown for hay and molasses. Lb. $20 \mathrm{c}$

TEXAS SEEDED RIBBON CANE (Gooseneck). -This is one of the largest varieties of Sorghums, resembling very much, as the name implies, the Ribbon Cane. 30c per pound.

HONEY DRIP or JAPANESE CANE.-Is the best syrup producer of all varieties and is a fine forage crop for green feeding and makes excellent hay. $30 \mathrm{c}$ per pound.

\section{Field Beans}

The Field Bean, both as a soil builder and a feed producer, is the greatest legume crop in existence, making a larger growth of vine and a heavier yield of seed.

EARLY SPECKLED VELVET BEANS.-The Early Speckled is a sport from the old Speckled variety which originated in Georgia. Price, 1b., 25c.

SOY OR SOJA BEANS.-This variety has been extensively advertised as the Coffee Bean, the seed being sometimes parched and ground for use as coffee. Price, 1b., 25c. By express, 10 lbs., $\$ 2.00$.

MEXICAN PINTO BEANS (Frijoles).-This now very popular bean is extensively grown in New Mexico and the dry sections surrounding. It has done well in the Panhandle and Western Texas. They are excellent when cooked, highly nutritive, and much preferred to other varieties. Price, $1 \mathrm{~b}$., 30c. By express, 10 lbs., $\$ 1.75$.

THE TEPARY BEAN.-This bean has been grown in some sections of the United States for 100 years or more. It is similar in size and looks like the Navy Bean. Price, lb., 30c. By express, 10 lbs., $\$ 1.75$.

\section{Clover}

SWEET CLOVER (White Blossom)- - Sweet Clover meets the approval of most every farmer who has given it a trial, as a valuable pasturage and soil restorer. For sheep, cattle and horses it is hard to equal and its blossoms will give more honey when used for bees than any other Clover. $60 \mathrm{c}$ per pound; 10 lbs., \$4.50.

BURR CLOVER IN THE BURR.-Lb., 20c; 10 lbs., \$1.75. RED CLOVER.-Lb., 75c.

WHTTE DUTCH CLOVER.-Lb., \$1.00.

ALS'KE CLOVER.-Lb., 85c; 10 lbs., \$6.00.

JAPAN CLOVER.-Lb., 90c; 10 lbs., $\$ 7.50$.

CRIMSON CLOVER.-Lb., 35c; 10 lbs., \$2.50.

\section{Cotton Seed}

If you are in the market for any quantity we would be glad to submit samples and quote you prices.

MEBANE'S TRIUMPH BIG BOLL.-One of the best extra early cottons; heavy yielder. Write for prices.

ROWDEN FANCY BIG BOLL.-Heavy yielder, practically stormproof and one of the best cottons for North and East Texas. Write for prices.

LONE STAR COTTON.-This cotton is of medium height with one to four limbs and many long branches. The staple is long, measuring from one to one and one-eighth inches, very strong and of uniform length. Lone Star Cotton usually brings a premium in price over most other varieties. Write for prices.

\section{Wheat}

BLUE STEM MEDITERRANEAN WHEAT.-A variety that has been greatly favored by many southern growers for years. 20c per lb.; 10 lbs., \$1.75; peck, $75 \mathrm{c}$; bu., $\$ 2.75$.

MIRACLE WHEAT.-This wheat has been thoroughly tested the last few years and has proved a great success in North Texas. It is a pure soft bearded wheat, has a large plump berry and does not shatter like Mediterranean. 20c per lb. peck, $75 \mathrm{c}$; bu., $\$ 2.75$.

NICARAGUA or MACARONI WHEAT.-This is a hard wheat which is yearly growing more popular in Texas. It is the only wheat we have which will succeed well planted in the spring. It is the best wheat known for making macaroni. 20c per lb.

\section{Lang's Seed Corn}

\section{GROWN FOR SEED, SELECTED, GRADED AND TESTED}

The prices quoted below are postpaid up to and including 2 lbs. They are subject to market changes and we would advise writing before ordering any large quantities. We will be glad to submit samples and quote you our very lowest current prices.

\section{NORTHERN RAISED CORN.}

CHAMPION WHITE PEARL.-The stalk is short and thick. The ears grow long on the stalk, from 7 to 12 inches in length, almost parallel throughout, of medium size, averaging 16 rows of grains. $25 \mathrm{c} 1 \mathrm{~b}$.

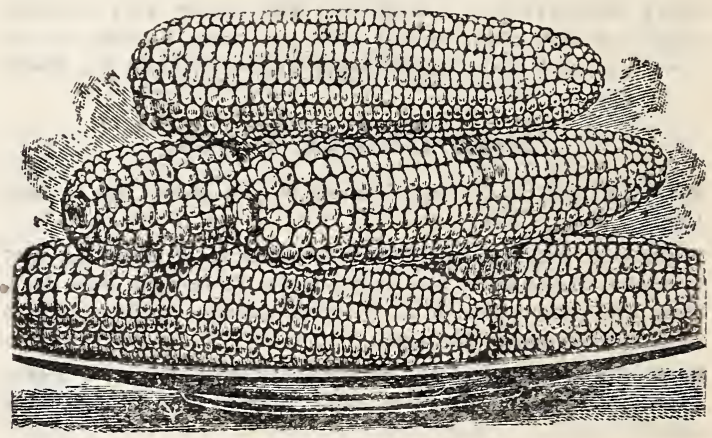

IOWA SILVER MINE

IOWA SILVER MINE (100 Days).-Silver Mine is deep grained, pure white, rough topped, with a small white cob. Ears run from 9 to 12 inches long, with 16 to 20 rows of pure white kernels. Price, 25 c lb.; peck, $\$ 1.00$; bu., \$3.50.

IOWA GOLD MINE-Earliest to mature. the purest yellow; the deepest grain. Price, $25 \mathrm{c}$ lb.; peck, $\$ 1.00$; bu., $\$ 3.50$.

EARLY LEAMING.-This is the earliest Yellow Dent Corn in cultivation, maturing in 80 to 85 days from planting. Price, 25c lb.; peck, $\$ 1.00$; bu., $\$ 3.50$.

HICKORY KING (110 Days).- This is an entirely distinct variety amongst the white corn, combining the largest grain with the smallest cob. A good drought resister. We recommend it very highly. Price, $25 \mathrm{c}$ lb.; peck, $\$ 1.00$; bu., $\$ 3.50$. TEXAS GROWN VARIETIES.

OKLAHOMA WHITE WONDER.-This is one of the best drought-resisting varieties, almost equal to June corn. Can be planted as late as June with good results. It ripens at the same time as the earliest varieties, and is the only large-eared corn we know of that ripens so soon. Price, lb., $25 \mathrm{c}$; peck, $\$ 1.00$; bu., $\$ 3.50$. 


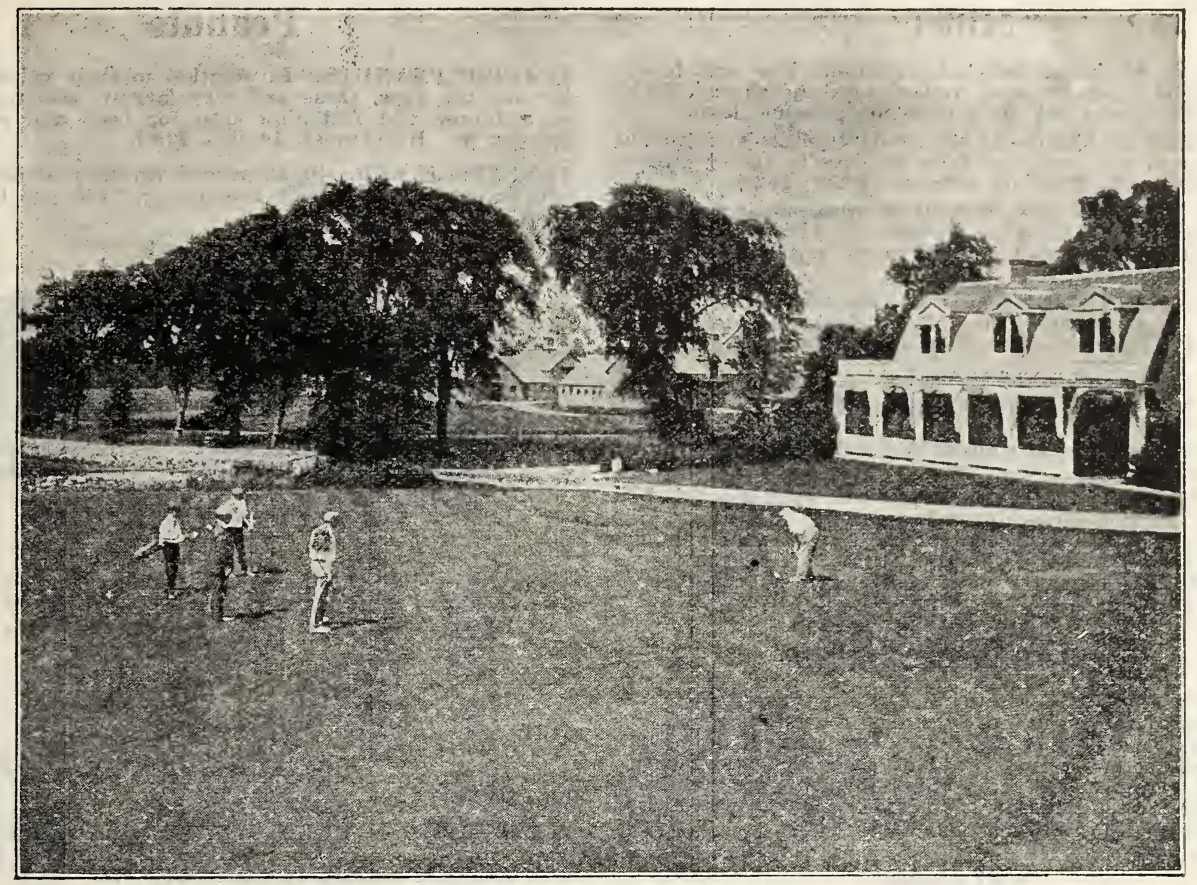

LANG'S LAWN GRASS MIXTURE

SURCROPPER.-This is an excellent variety for both early and late planting. It requires about 110 to 120 days to mature. Price, lb., 25c; peck, $\$ 1.00$; bu., $\$ 3.50$.

GIANT YELLOW DENT.-This fine yellow corn is a splendid variety, well suited to the South Our stock this year is fine; every ear was carefully selected before shelling. Price, b., 25c; peck, $\$ 1.00 ;$ bu., $\$ 3.50$.

GIANT WHITE (Red Cob).-This corn has more notes of distinction than any other variety. It has red cob and large white grains. The Giant White makes the finest meal, roasting ears and hominy, and is the finest quality of corn that grows. Matures in 100 to 110 days. Price, lb., 25c; peck, $\$ 1.00$; bu., $\$ 3.50$.

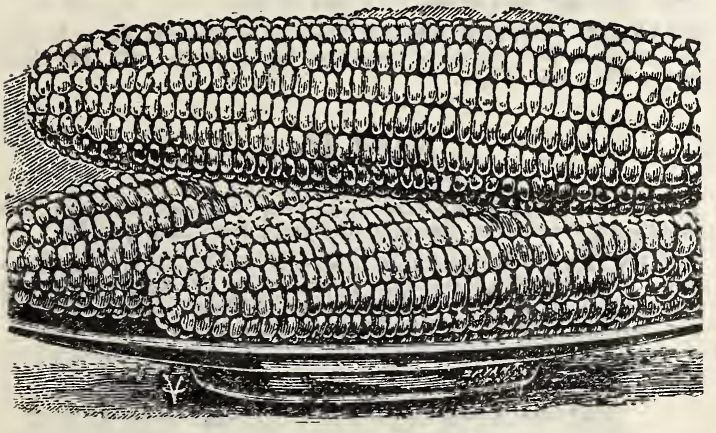

BLOODY BUTCHER CORN

BLOODY BUTCHER.- This is one of the very best corns for rexas. It matures in about 100 days. Price, lb., 25c; peck, $\$ 1.00$; bu., $\$ 3.50$.

STRAWBERRY.-This corn has always done well in Texas. Price, 1b., 25c.

\section{JUNE CORN.}

NATIVE GROWN MEXICAN JUNE CORN.-This variety has become well known among the most progressive farmers of the Southwest, having proven itself worthy of a high place in the corn family of the Southern states. Price, lb., 20c.
IMPROVED SQUAW.-Originated in Oklahoma, and is one of the most popular varieties of corn. It is a natural drought-resisting variety. The grains present a combination of colors; some are red, others yellow, blue and white. Price, lb., 30c.

\section{Grasses}

JOHNSON GRASS (Sorghum Halapense).-Perennial grass, with long, cane-like roots. Leaves, stalks and panicles resemble those of sorghum. 60c per lb. By frieght or express, 10 lbs., $\$ 4.00$.

RESCUE GRASSES.-This is the best winter grass we have in the South and deserves the attention of everyone who has stock to graze in the winter. It is an annual, but seeds itself. After the grass dies down in summer a crop of cowpeas or Japan Clover can be planted, but should be harvested great milk-producing qualities. Pkt., $5 \mathrm{c}$; oz., 10c; 1/4 lb., $20 \mathrm{c}$; lb., 65c.

MAMMOTH LONG RED.-Grows to very large size and good keeper. Pkt., 5c; oz., 10c; lb., 65c.

YELLOW MILO MAIZE.-This excellent fodder plant has proved of great value during dry years in Texas. Five pounds will plant an acre. Price, lb., 15c; peck, $\$ 1.00$; bu., $\$ 3.75$.

WHITE MILO MAIZE-Is much the same as the Yellow Milo except that the grain is pure white, and it makes a heavier head. Price, lb., 20c; peck, $\$ 1.00$; bu., $\$ 3.75$.

EGYPTIAN WHEAT.-A valuable grain for stock feeding. Plant like kafir corn or milo maize. Makes valuable forage as well as heavy yield of grain. Price, lb., 25c.

JERUSALEM CORN. - The best and surest grain crop for dry countries-even better than Kafir Corn, Dhoura and Milo Maize. The grains are pure white and nearly flat. Three pounds will plant an acre. Price, 1b., 25c.

\section{Sunflower}

MAMMOTH RUSSIAN.-One of the best egg-producing foods known for poultry. Just what you need to fill up the vacant spots in your garden where the soil is not easily cultivated. $30 \mathrm{c}$ per $\mathrm{lb}$. By express, $10 \mathrm{lbs}$., $\$ 2.00$.

\section{Oats}

TEXAS RED RUST-PROOF-Is the finest oat grown, and we believe the grade has been, by careful selection of seed stock, greatly improved the last few years. We recommend early fall and early spring planting. 15c per lb., $10 \mathrm{lbs}$., $\$ 1.50$. 


\section{Millet}

Millet is an important and nutritious hay and forage crop, splendid for dairy cows, young stock and sheep. Yields heavily. Two crops can be grown on the same land.

BIG GERMAN MILLET.-It has produced from four to five tons of hay to the acre, and from seventy to eighty bushels of seed. Price, lb., 25c. By express, 10 lbs., $\$ 1.50$.

COMMON MILLET.-Sow in drills or broadcast from May to last of July. Price, lb., 25c. By express, 10 lbs., \$2.00.

PEARL MILLET.-Grows from 8 to 10 feet high; makes a splendid hay. Price, lb., 35c.

NEW JAPANESE BARNYARD MILLET.-Entirely distinct from any other variety. Grows 6 feet high and yields enormously. Has been called "Billion Dollar" grass. Price, lb., 30c.

\section{Schrock-Kafir}

It resembles kafir in waiting for rain, the leaves rolling up in daytime.

Everything likes the hay. As you will see from this and later know from observation, it has several advantages over Feterita, in that the seed does not shatter, the stalks do not fall or lodge and seed all gets ripe at once. Also the fodder and the stalk make the best of feed, which is not true of Feterita. 25 c per $1 b$.

\section{Dwarf Essex Rape}

Sow in summer for fall and winter pasture. It is especially good for sheep, but all kinds of stock and chickens are fond of it and do well on it. One acre of Rape will furnish pasture for twenty head of sheep for two months. It is good to use as a "catch crop" sown on ground where other crops for some reason have failed, as it grows quickly. 30 c per lb.; 10 lbs., $\$ 2.00$.

\section{Vetches}

THE WONDERFUL SAND or HAIRY VETCHES (Vicia Villosa).-Also called Winter Vetch. This useful plant is in time to allow the Rescue Grass to start again in the fall. $35 \mathrm{c}$ per lb. By express, $10 \mathrm{lbs} ., \$ 2.50$.

SUDAN GRASS.-Sudan is a tall, annual grass, reaching a height of from seven to nine feet when planted in rows and allowed to mature for a seed crop broadcasted and cut "in the bloom" for hay, about four feet. Yields 500 to 1,000 lbs., seed or three tons cured hay per cutting per acre with three cuttings per season. 30c per lb. By express, $10 \mathrm{lbs} .$, $\$ 2.00 ; 100$ lbs., $\$ 18.00$.

KENTUCKY BLUE GRASS (Poa Pratensis).-It is the best pasture for the climate and soil, succeeding finely on hill lands and producing the most nourishing food for cattle. Fancy cleaned seed, 60c per lb. By express, $10 \mathrm{lbs} ., \$ 5.00$. BERMUDA GRASS (Cynodon Dactylon).-One of the most valuable grasses for pastures and hay in the South, where it will stand indefinitely if plowed and harrowed in the spring once every four or five years. Best grade of new crop seed, thoroughly recleaned. $\$ 1.00$ per $\mathrm{lb}$. By express, $10 \mathrm{lbs} .$, $\$ 6.00$.

\section{Lawn Grass Mixture}

WINTER SOWING.-There is no better seed than is put in this mixture for the making of good lawns.

It consists of blue grass, red top, Bermuda grass, white clover, English rye and timothy, which assures a quick growth.

Price: $75 \mathrm{c}$ per lb.; 3 lbs., $\$ 2.00 ; 10$ lbs., $\$ 6.00$, prepaid. PERENNIAL ENGLISH RYE (Laliym Perenne).-A hardy rye grass, grows well on clay soil and withstands drought reasonably well; grows quick and is a good pasture grass. White Clover is sometimes used with this when used for lawn purposes. Price, lb., 40c. By express, 10 lbs., $\$ 3.00$.

\section{Stock Beets}

\section{MANGELS FOR FEEDING STOCK}

GIANT FEEDING SUGAR BEET (or Half Sugar Mangel). -Easily grown and harvested, and combines the highly nutritive value of a Sugar Beet with the large size of a MangelWurzel. Pkt., 5c; oz., 10c; $1 / 4$ lb., 20c; lb., 65c. Not prepaid, lb., 60c; 10 lbs., $\$ 5.00$.

MAMMOTH GOLDEN TANKARD.-Flesh a golden, and of noted for its extreme hardiness and is valuable for forage and fertilizing purposes. It is an annual, but drops its seeds freely and will come up year after year on the same ground. 75c per lb. By express, 10 lbs., $\$ 6.00$.

\section{Peanuts}

SPANISH PEANUTS. - In addition to their value for grow. ing for the nuts, these are very largely used in the South as a forage and fattening crop for hogs and other stock. $30 \mathrm{c}$ per lb. By express, $10 \mathrm{lbs}$.; $\$ 2.00$.

TENNESSEE RED.-Small-podded variety; similar to Spanish, except that the pods are longer. 40c per lb. By express, 10 lbs., $\$ 2.50$.

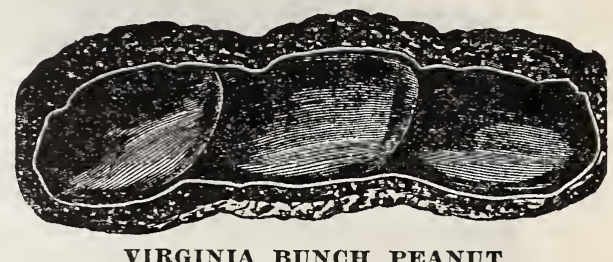

VIRGINIA BUNCH PEANUT

VIRGINIA BUNCH.-A very profitable variety, plant rather dwarf. It is the standard variety for roasting. They furnish excellent forage. $40 \mathrm{c}$ per $\mathrm{lb}$. By express, $10 \mathrm{ibs}$., $\$ 2.50$.

\section{Field or Cowpeas}

WHIPPOORWILL.-Has brown, speckled seed, easily gathered on account of the upright, bushy growth of the plants. Lb., 20c.

WONDERFUL or UNKNOWN.-In yield and in growth of vines surpasses any other varieties; requires a long season and should be planted in May. Lb., 30c.

LARGE BLACK-EYE.-The dry peas, which are produced in large quantities, find a ready sale during the winter. Lb., 30c.

CREAM PEAS.-Plants form sturdy bushes which produce the pods in bunches. These are of creamy yellow color. Lb., 30c.

BROWN CROWDER PEAS.-This is a native Texas Pea, exceptionally fine for table use and very prolific. Lb., 30c.

\section{Barley}

BEARDLESS BARLEY.-This is a spring barley and should be planted about the last of February or first of March. It is beardless as the name implies, making it a fine stock feed. $20 \mathrm{c}$ per lb.; peck, 75c; bu., \$2.75.

BEARDED WINTER BARLEY.-This variety is sown in the fall and makes excellent pasture for winter. 20c per lb.; peck, $75 \mathrm{c}$; bu., $\$ 2.75$.

\section{Seed Rye}

FALL OR WINTER.-The time for sowing is from the middle of August to the last of September. 20c per lb.

ROZEN RYE.-Within the past few years there has been quite a big demand for this new variety of Rye, for it has made good in every Southern state, without exception. 25c per lb.; peck, $75 \mathrm{c}$; bu., $\$ 2.75$, express collect.

\section{Non-Saccharine Sorghums}

WHITE KAFIR CORN.-Grows 4 to 5 feet high. The stems are very leafy and keep green and brittle, unlike other sorghums, which harden. Price, lb., 20c.

RED KAFIR CORN.-Grows taller than the white; stalks slender, juicy and very leafy. The seed is red, smaller than that of the white, and hard and brittle. Ripens earlier than that of the white and yields much heavier. Price, lb., 15c; peck, $\$ 1.00$; bu., $\$ 3.75$.

FETERITA.-Feterita grows about five feet high on an average, and a crop of it growing looks very much like a crop of kafir or dwarf white milo. The heads grow up straight like kafir and are a little larger around but not quite so long. Price, lb., 25c; peck, $\$ 1.25$; bu., $\$ 4.00$. 


\section{Vegetable Seeds That Grow}

Your orders, no matter how large or how small, will always receive our prompt attention.

ALL SEEDS sold in packet, ounce, pound, prepaid by mail, unless it be varieties listed by express at purchaser's expense, or otherwise stated.

ALL SEEDS in lots over one pound, gallon, peck, bushel to go by express or freight at purchaser's expenses unless otherwise stated. The price has been reduced to the lowest figure for choice stock.

\section{Beans}

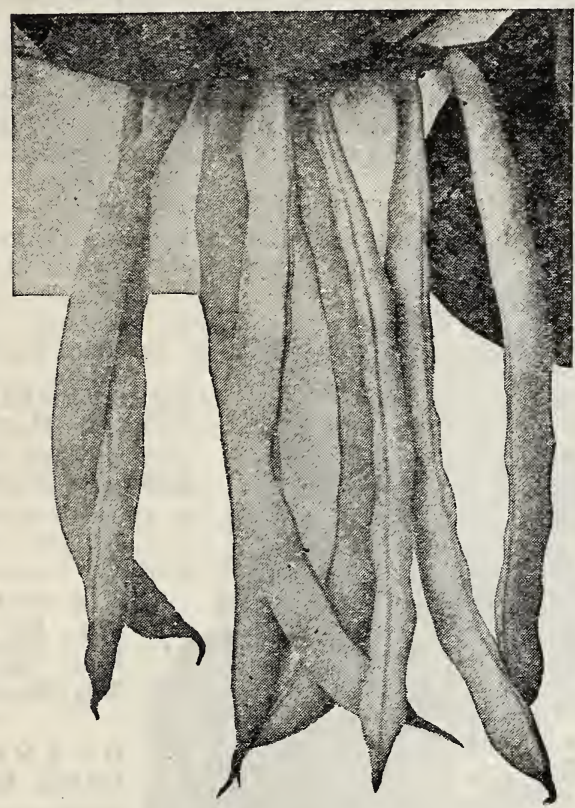

We have our stock grown on contract by one of the most reliable Bean Seed growers in Michigan, and feel sure they will give the best of satisfaction.

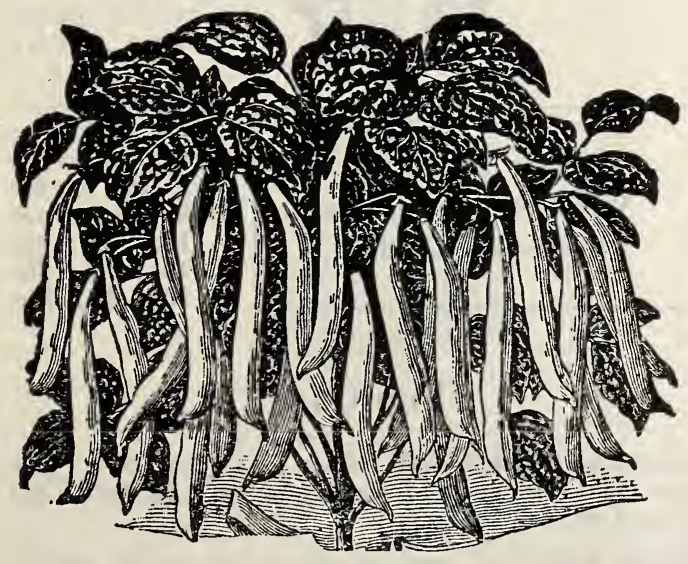

IMPROVED GOLDEN WAX

\section{BUSH WAX PODDED}

IMPROVED GOLDEN WAX (Rust-Proof).-Very valuable, rust-proof strain of Golden Wax. Pkt., 10c; lb., 30c; 2 lbs., $55 \mathrm{c}$, postpaid.

DWARF GERMAN BLACK WAX.-Very prolific strain of the Black Wax, with long, round pod of attractive, waxy yellow color. Pkt., 10c; lb., 30c; 2 lbs., 55c, postpaid.

WARDWELL'S KIDNEY.-Quite extensively grown in Southern Texas for shipping to distant markets. Pkt., 10c; lb., 30 ; 2 lbs., 55c, postpaid.

\section{BUSH GREEN PODS}

EXTRA EARLY RED VALENTINE.-This is a round pod bean, very tender and the earliest of all bush beans, very desirable for the home garden. Pkt., 10c; lb., 30c; 2 lbs., $55 \mathrm{c}$, postpaid.

GIANT STRINGLESS.-One of our most prolific producing varieties, somewhat later than the Early Valentine, but a more abundant producer. Pkt., 10c; lb., 30c; 2 lbs., 55c, postpaid.

BURPEE'S STRINGLESS. - This is the most popular of our green pod beans and the varieties very much planted by our market gardeners. Pkt., 10c; 1b., 30c; 2 lbs., 55c, postpaid.

TENNESSEE GREEN POD.-This early intermediate snap bean is very popular in the South. Pkt., $10 \mathrm{c} ; 1 \mathrm{~b} ., 30 \mathrm{c} ; 2 \mathrm{lbs}$., $55 \mathrm{c}$, postpaid.

LONGFELLOW-Vigorous in growth, 16 inches tall, bearing abundance of pods 5 to 6 inches long; round, slightly curved, stringless when young, of good quality. Pkt., 10c; lb., $30 \mathrm{c}$; 2 lbs., $55 \mathrm{c}$, postpaid.

REFUGEE, or THOUSAND-TO-ONE.-Somewhat later than the other green podded sorts, but very prolific. Pkt., 10c: lb., 30c; 2 lbs., 55c, postpaid.

\section{POLE OR CLIMBING SORTS}

THE KENTUCKY WONDER.-The greatest of all pole beans, almost a continuous bearer, producing pods 6 to 9 inches long, which are very tender. Pkt., 10c; 1b., 30c; 2 lbs., 55c, postpaid.

WHITE CREASEBACK. - Mostly planted by our country cousin on account of its wonderful producing qualities. Pkt. 10c; lb., 30c; 2 lbs., 55c, postpaid.

LAZY WIFE.-A remarkable variety, not only for its great productiveness, but also for its fine quality; the pods are produced in clusters, and almost a handful can be grasped at once. Pkt., 10c; lb., 30c; 2 lbs., 55c, postpaid.

\section{BUSH LIMA BEANS}

HENDERSON DWARF OR BUSH LIMA.-A very desirable variety for the home gardener and a prolific producer. Pkt., 10c; lb., 35c; 2 lbs., 65c, postpaid.

BURPEE'S BUSH LIMA.-A true bush form, growing 18 to 20 inches high; an immense yielding variety. Pkt., 10c: lb., $35 \mathrm{c} ; 2$ lbs., $65 \mathrm{c}$, postpaid.

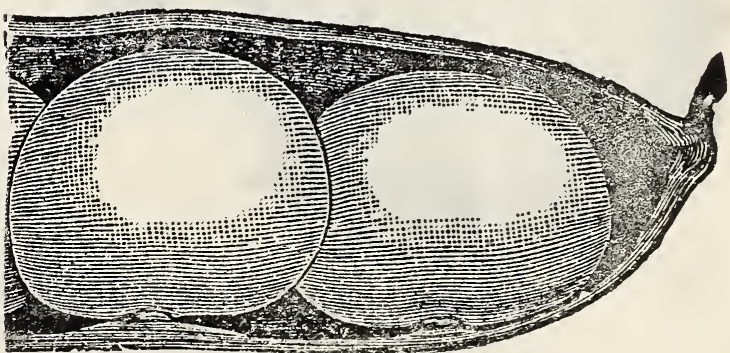

POLE LIMAS

SMALL WHITE LIMA OR SIEVA-A very early variety, valuable for the truck growers on account of its wonderful productiveness. Pkt., $10 \mathrm{c}$; 1b., 35c; $2 \mathrm{lbs}$., $65 \mathrm{c}$, postpaid. KING OF THE GARDEN. - This is the large variety, very productive and will bear until frost if picked often and not allowed to ripen on the vines. Pkt., $10 \mathrm{c}$; lb., $35 \mathrm{c} ; 2$ lbs., $65 \mathrm{c}$, postpaid. 


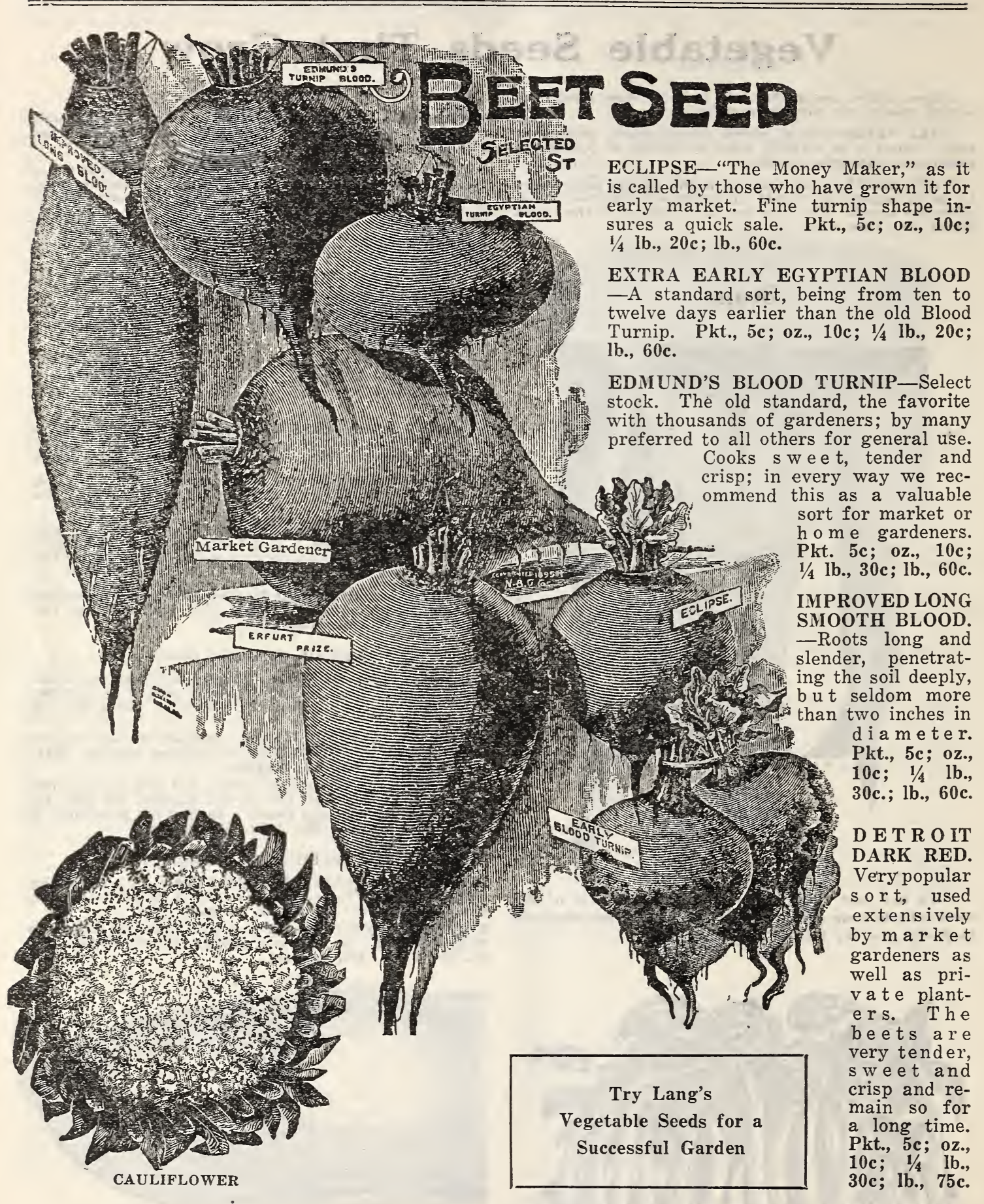

\section{Cauliflower}

EARLY SNOWBALL FORCING.-The market gardeners' favorite. Stands the heat and drought better than most Caulifluwers. Pkt., 25c; oz., $\$ 3.00$.

SELECTED DWARF ERFURT.-Excellent for forcing as well as open ground. The plants are small-leaved and dwarf, producing pure white heads of finest quality. Pkt., 25c; oz., $\$ 3.00$.

\section{Pop Corn}

QUEEN'S GOLDEN.-The largest of all Pop Corin. It is cream in color, but pops perfectly white. Lb., 30c. Not postpaid, 10 lbs., $\$ 1.75$.

WHITE RICE.-The most popular widely known variety. Lb., 20c; 10 lbs., \$1.75, by express. 


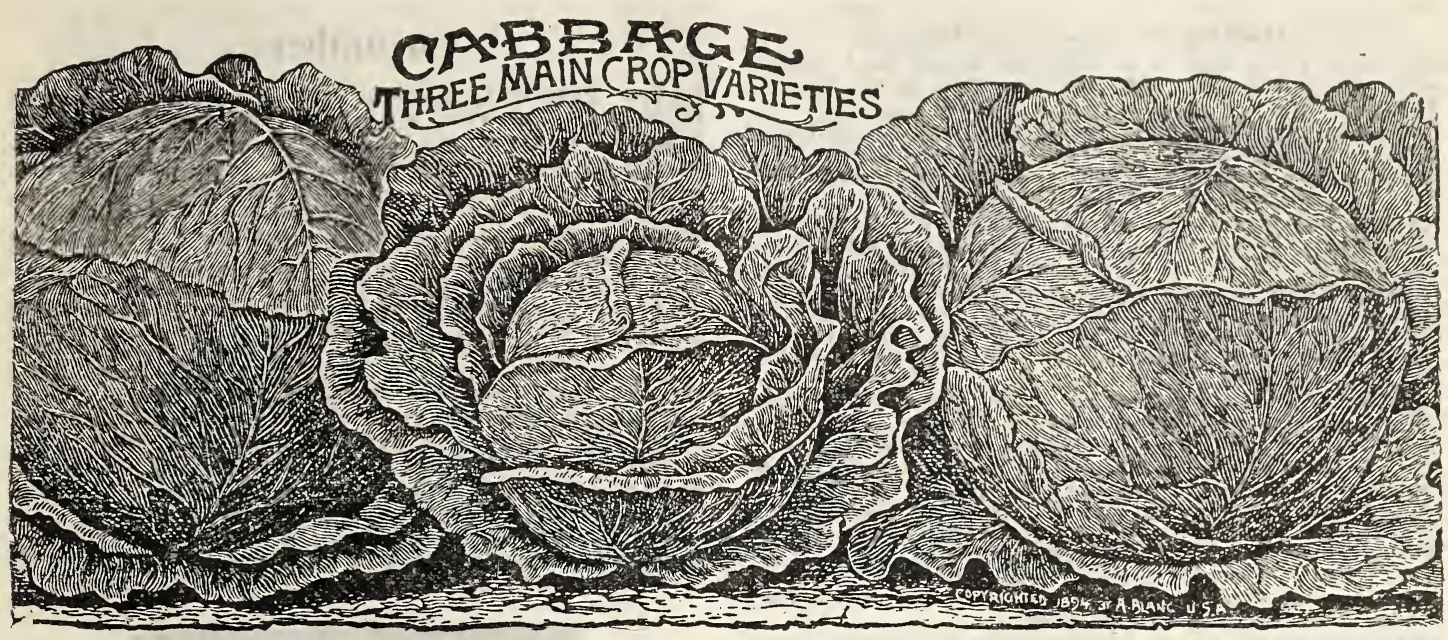

SUREHEAD

SUCCESSION

ALL SEASONS

\section{Cabbage}

HENDERSON'S EARLY SUMMER.-Our strain of this standard early variety has been carefully selected each season and we pride ourselves on being able to offer a strain of Early Summer that cannot be surpassed. Pkt., 10c; oz., 20c ; $1 / 4$ lb., 50c; lb., $\$ 2.00$.

EARLY DWARF FLAT DUTCH.-A standard sort that seems to increase in popularity each season. The plants are short-stemmed and upright with comparatively few and short leaves, so that they may be planted very close together. Pkt., 10c; oz., 20c; $1 / 4$ lb., 60c; lb., $\$ 2.00$.

STEIN'S EARLY FLAT DUTCH.-A distinct strain of quick growing and early maturing. Immense growth, weighing 10 to 12 lbs. Pkt., 10c; oz., 25c; 1/4 lb., \$1.00.

JERSEY WAKEFIELD. - Carefully selected seed. For over twenty years Jersey Wakefield has held its own with other cabbages and our enormous sales of this variety every sea(Continued on Page 42.)

\section{Swiss Chard \\ GROWN FOR LEAVES ONLY.}

SWISS CHARD (Sea Kale, or Spinach Beet).-This kind of beet is grown exclusively for the numerous fleshy, tender leaves and leaf stalks, which are superior to those of other beets for greens. Pkt., 5c; oz., 10c; $1 / 4$ lb., 25c; 1b. 75c.

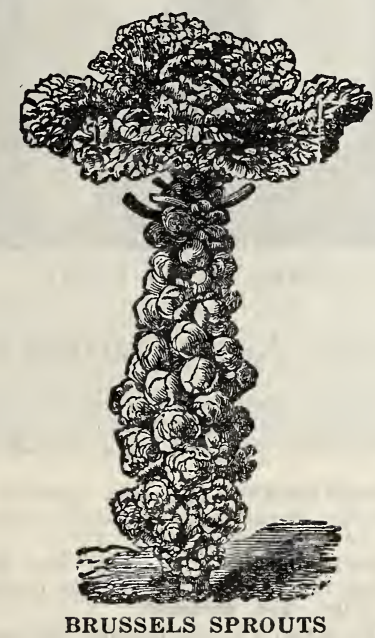

\section{Brussels Sprouts}

BRUSSELS SPROUTS are a very delicate vegetable and deserve a more general cultivation than they receive. The plant belongs to the cabbage family, and should be grown and cultivated like cabbage. The "sprouts" which grow around the strong, upright stems of the plant look like miniature cabbages. Very hardy ; improved by frost. Pkt., $10 \mathrm{c} ; 0 \mathrm{z} ., 15 \mathrm{c}$.

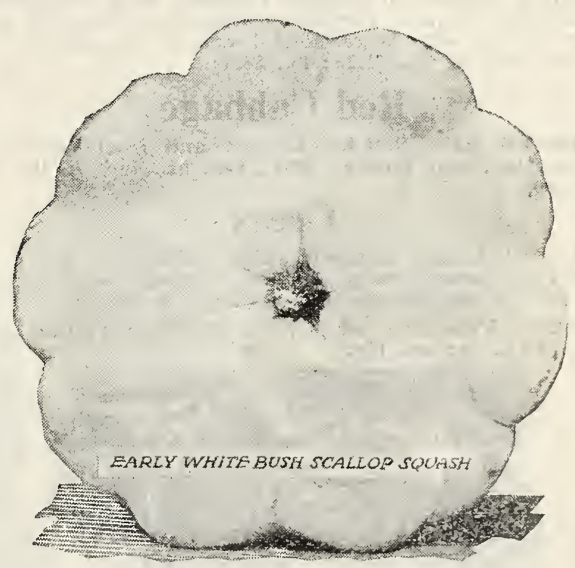

\section{Squash}

YELLOW SUMMER CROOKNECK.-A small crookneck sort. Skin bright yellow; very early and productive. Pkt., 5c; oz., 10c; 1/4 lb., 35c; lb., \$1.25.

WARTED HUBBARD.-This is similar in size and quality to the well known Hubbard. The vines are fully as vigorous and productive, while the dark olive green fruits are rather more heavily warted. Very handsome in appearance. An excellent keeper. Pkt., 10c; oz., 15c; 1/4 lb., 55c; lb., $\$ 2.00$. BOSTON MARROW.-A fall and winter variety of medium large size, oval shape, bright orange color, with a shading of light cream color. Flesh rich yellow, fine grained, rich, delicious flavor. Pkt., 5c; oz., 10c; $1 / 4$ lb., 40c; lb., \$1.35. 
(CABBAGE-Continued From Page 41.)

son prove to us that it is still one of the most popular sorts ever introduced. Pkt., 10c; oz., 20c; 1/4 1b., 55c; lb., $\$ 2.00$.

COPENHAGEN MARKET.-The earliest, large, round-headed Cabbage yet introduced. The heads are exceptionally large for so early a variety, very solid and of most excellent quality. Pkt., 10c; oz., 30c; 1/4 lb., 75c; lb., $\$ 2.50$.

EARLY DRUMHEAD or SHORT STEM.-One of the best second early varieties. Head large, flat, compact, solid and of fine quality. Price, pkt., 10c; oz., 20c; 1/4 lb., 65c; lb., \$2.35. CHARLESTON WAKEFIELD.-A very popular variety with market gardeners in the South. It is a week later than Early Jersey Wakefield, but the heads are nearly one-half larger. Does not burst when ripe. Pkt., 10c; oz., 20c; 1/4 lb., $60 \mathrm{c}$; lb., $\$ 2.00$.

SUREHEAD. - Burpee's Surehead is a most popular strain of the favorite Flat Dutch type of cabbage. Pkt., 10c; $1 / 2$ oz., 20c; oz., 30c; $1 / 4$ lb., 90c; lb., $\$ 3.00$, postpaid. ALL SEASONS.-Heads large, solid and of excellent keeping qualities. Fine for shipping purposes. A splendid cabbage for general use. In quality, tenderness and flavor no Drumhead can surpass our selected strain of All Seasons. Pkt., 10c; oz., 30c; 1/4 lb., 75c; lb., \$2.50.

SUCCESSION.- The best general crop cabbage in the world. Surest heading late sort. Keeping qualities unequaled. Pkt., $10 \mathrm{c}$; oz., 20c; 1/4 lb., 60c; lb., $\$ 2.00$.

PREMIUM LATE FLAT DUTCH.-This is a large, strong growing variety, requiring a considerable length of season in which to perfect the large, solid flat heads. Pkts., 10c; oz., 20c; $1 / 4$ lb., 60c; lb., $\$ 2.00$.

\section{Chinese Cabbage}

PE-TSAI.-Improved Chinese Cabbage. The market appearance of this cabbage in quantity the past two years has created a wide-spread demand for the seed. It has a mild flavor and may be eaten raw or as a salad, or cooked. Boiled, minced and seasoned with butter, it is especially delectable. Pkt., 10c ; 1/2 oz., 25c ; 0z., 45c; 1/4 lb., \$1.50.

\section{Savoy Cabbage}

PERFECTION DRUMHEAD SAVOY.-Savoy Cabbage is very much superior to ordinary Cabbage, as it is more tender and of finer flavor. Perfection Drumhead Savoy is an excellent strain, with large, solid heads of fine quality. Pkt. $10 \mathrm{c}$; oz., $40 \mathrm{c}$; $1 / 4 \mathrm{lb}$., $\$ 1.25$; lb., $\$ 4.00$.

\section{Red Cabbage}

MAMMOTH RED ROCK.-Largest and most solid of the red varieties; very tender. Pkt., 10c; oz., 40c; $1 / 4 \mathrm{lb} ., \$ 1.25$; lb., \$4.00.

\section{Cress}

A well known pungent salad. Requires to be sown thickly and covered very slightly, at frequent intervals, to keep up a succession, as it soon runs to seed.

CURLED.-Very fine for salad; will bear cutting several times. Pkt., 5c: oz., 15c.

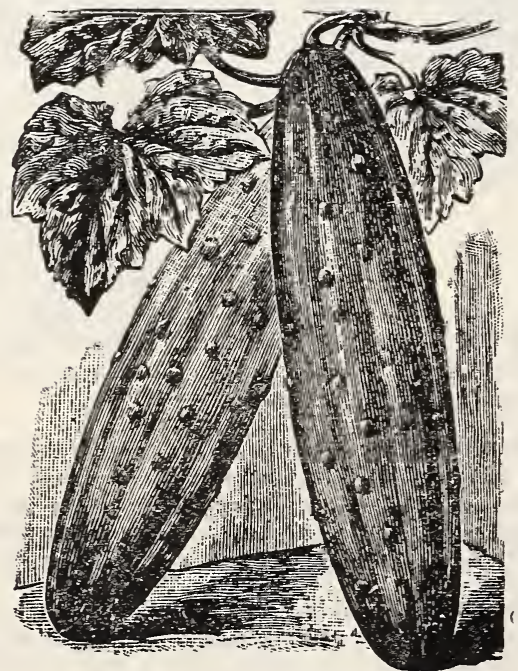

ARLINGTON WHITE SPINE

\section{Cucumbers}

DAVIS' PERFECT.-Color a dark glossy green. Length 10 to 12 inches. Pkt., 5c; oz., 20c; $1 / 4$ lb., 60c; 1 b., $\$ 2.00$. BOSTON PICKLE.-An abundant bearer; highly recom. mended for pickles. Pkt., 5c; oz., 10c; 1/4 lb., 30c; lb., \$1.00. NEW KLONDIKE.-An attractive dark green sort. The fruits average 6 to 7 inches long and 2 inches in diameter. When small, make excellent pickles. Pkt., 5c; oz., 10c; $1 / 4$ lb., 30c; lb., $\$ 1.00$.

JAPANESE CLIMBING CUCUMBERS.-A marvelous climb. ing variety introduced from Japan. The cucumbers are about ten inches in length, and of a beautiful green color; the flesh is firm and free from the bitter taste found in some varieties. It can be trained on poles, trellises, fences. Pkt., $10 \mathrm{c} ;$ oz., 15c; $1 / 4$ lb., 35c; lb., $\$ 1.25$.

ARLINGTON WHITE SPINE.-The truckers' favorite. Very early: color deep green. Pkt., 5c; oz., 10c; 1/4 lb., 30c: lb., $\$ 1.00$.

EARLY CLUSTER.-Fruits small dark green; borne in clusters. Pkt., 5c; oz., 10c; $1 / 4$ lb., 30c; lb., $\$ 1.00$

IMPROVED LONG GREEN.-Most widely cultivated sort. Unsurpassed for general use. The cucumbers average 12 inches long. Pkt., 5c; oz., 10c; 1/4 lb., 30c; lb., \$1.00.

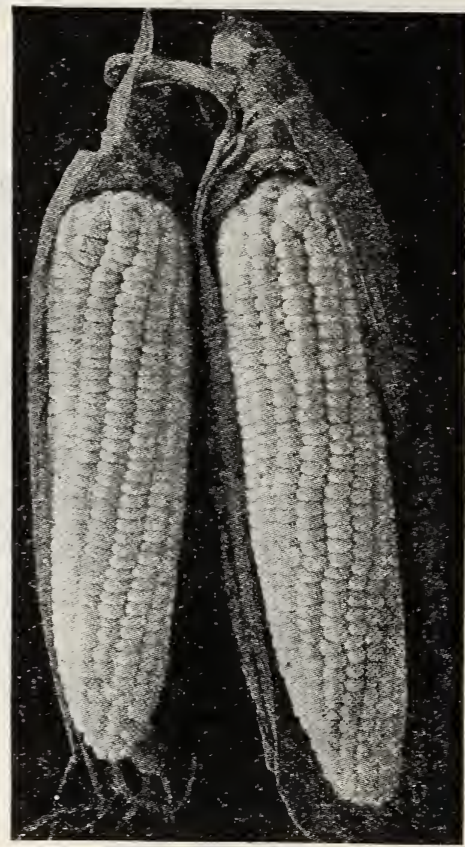

ADAMS' EARLY LARGE

\section{Sweet Corn-Early Garden Varieties}

GOLDEN BANTAM.-Early Sweet Corn, with yellow kernels. Very sweet and delicious; tender and of excellent quality. One of the best early varieties. Pkt., 10c; lb., 50c; 2 lbs., $90 \mathrm{c}$, postpaid.

COUNTRY GENTLEMAN.-The most delicious of all Sweet Corns, and also one of the most productive sorts. Pkt., 10c; lb., $25 \mathrm{c} ; 2$ lbs., $45 \mathrm{c}$, postpaid.

STOWELL'S EVERGREEN.-The best late sweet corn in every way, being large eared, hardy and productive. Pkt., 10c; lb., 20c; 2 lbs., 35c, postpaid.

ADAMS' EXTRA EARLY.-The hardiest and earliest variety. It is not a Sweet Corn, but produces ears well filled with tender white grains. Pkt., 10c; lb., 20c; 2 lbs., 35c, postpaid.

ADAMS' EARLY LARGE.-One of our leading varieties. Ears are large and handsome. Pkt., 10c; lb., 20c; 2 lbs., 35c, postpaid.

HICKORY KING, IOWA SILVERMINE and WHITE PEARL are all good to plant for roasting ears. Pkt., $10 \mathrm{c}$; lb., 20c; 2 lbs., 35c, postpaid. For larger quantities see Field Corn. 


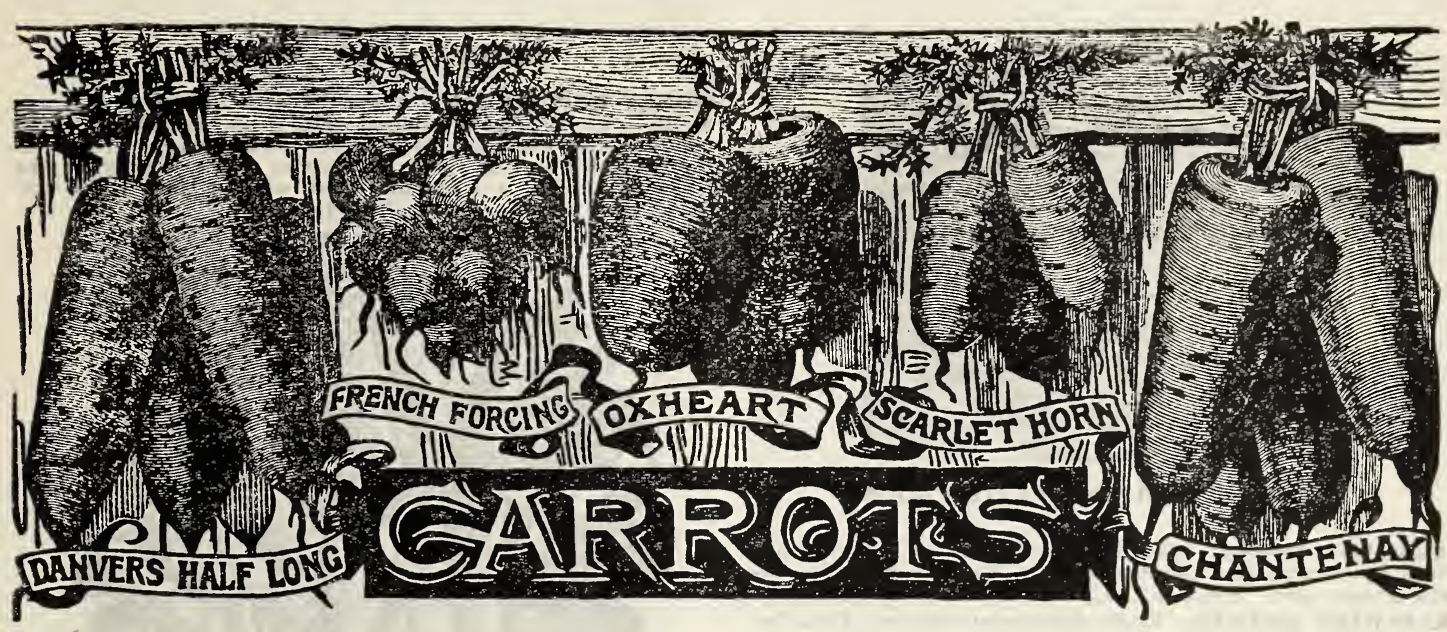

\section{Carrots}

EARLY SCARLET HORN.-Stump root. Is popular for forcing and early outside sowing. Flesh deep orange, small tops. Pkt., 5c; oz., 10c ; $1 / 4$ lb., 20c; lb., 75c.

OXHEART. - A desirable variety on soil too hard and stiff for the longer growing sorts. Pkt., 5c; oz., $10 \mathrm{c}$; $1 / 4 \mathrm{lb}$., $20 \mathrm{c}$; lb., 75c.

HALF LONG DANVERS.-Improved stock. One of the most productive for field culture. Pkt., 5c; oz., 10c; $1 / 4$ lb., 20c; 1b., 75c.

LONG ORANGE.-The best late variety for field culture. Pkt., 5c; oz., 10c; 1/4 lb., 20c; lb., 75c.

\section{Celery}

WHITE PLUME.-It is more largely grown for both private and market use than any other sort. In earliness it sur- passes any other celery, as it can be blanched for the table in September. Pkt., 5c; oz., 30c; $1 / 4$ lb., 90c.

GOLDEN SELF-BLANCHING. A grand sort on the style of White Plume, except that it is a golden yellow color. Pkt., 10c; 0z., 45c; 1/4 lb., \$1.40.

\section{Collards}

TRUE GEORGIA.-Pkt., 5c; oz., 10c; 1/4 lb., 30c; lb., $\$ 1.00$.

\section{Egg Plant}

IMPROVED NEW YORK SPINELESS.-Fruit of large size and perfect form. Pkt., 10c; oz., 35c; $1 / 4 \mathrm{lb}$., $\$ 1.25$.

BLACK BEAUTY.-Fruit large, dark purple. Pkt., 10c; oz., 35c; $1 / 4$ lb., $\$ 1.25$.

\section{Endive}

One of the best salads for fall and winter use. For greens and for flavoring soups and stews. Large pkt., 10c.

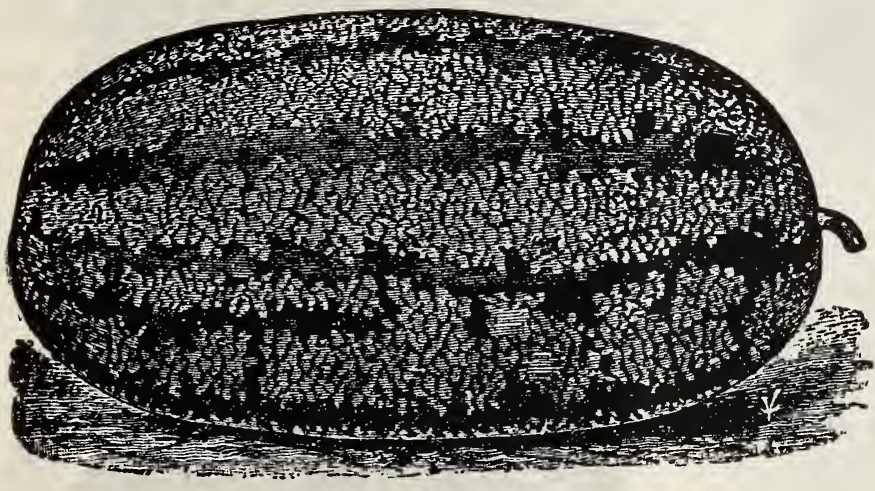

AMABAMA SWEET

is thick, green, well flavored and sweet. Pkt., 5c: oz., 10c; $1 / 4$ lb., 30c; lb., $\$ 1.25$.

NUTMEG GREEN.-A medium-sized globularformed variety, which is slightly ribbed; the skin is a rich, dark green. Pkt., 5c: oz., 10e $1 / 4$ lb., 30c; lb., \$1.25.

HACKENSACK or TURK'S CAP. - Very hardy, are of good size, round, heavily ribbed and netted. The meat is green, thick, firm, and of excellent flavor. Pkt., 5c; oz., 10c: $1 / 4$ lb., 30c; lb., \$1.25.

NETTED ROCK.-It is about the same size as Rocky Ford, heavily netted, the flesh is green, deep and solid and of very fine flavor. Pkt., 5c; oz.. 10c; $1 / 4$ lb., 30c; lb., \$1.25.

TEXAS CANNON BALL - Round, medium size, heavily netted, flesh green, very solid, melting and of delicious flavor. Pkt., 5c; oz. $10 \mathrm{c} ; 1 / 4$ lb., 30c; lb., $\$ 1.25$.

\section{Muskmelons}

LANG'S GOLD-LINED NETTED ROCK.-This melon we do not hesitate to recommend to the market gardener and large grower. Size runs from medium to large. They always bring the top price on the market. Pkt., 10c; 0z., 15c; $1 / 4 \mathrm{lb} ., 35 \mathrm{c}$; lb., \$1.25.

ROCKY FORD.- The melon that made Rocky Ford famous. The favorite green-fleshed shipping variety. Pkt., 5c; oz., 10c; $1 / 4 \mathrm{lb}$., 30c; lb., $\$ 1.00$.

BALTIMORE or ACME.-The fruits are medium sized, ova or long oval, slightly pointed at stem end, slightly ribbed and are covered when ripe with coarse netting. The flesh

\section{Watermelons}

GILBER'S EXCEL-It is a cross between Tom Watson and the Blue Gem. It is a dark green stripes; the flesh is of superb quality and intense red to the rind. Pkt., 10c; oz., 15c; $1 / 4 \mathrm{lb}$., 35c; lb., $\$ 1.00$.

TOM WATSON.-This is one of the best melons. Pkt., $5 c$; oz., $10 \mathrm{c}$; $1 / 4$ lb., $25 \mathrm{c}$; lb., 85c.

HALBERT HONEY.-A Texas melon and particularly adapted for our state Brings always higher prices than any other melon on the market. Pkt., 5c; oz., 10c; $1 / 4$ lb., $25 \mathrm{c}$; 1b., 85c. 


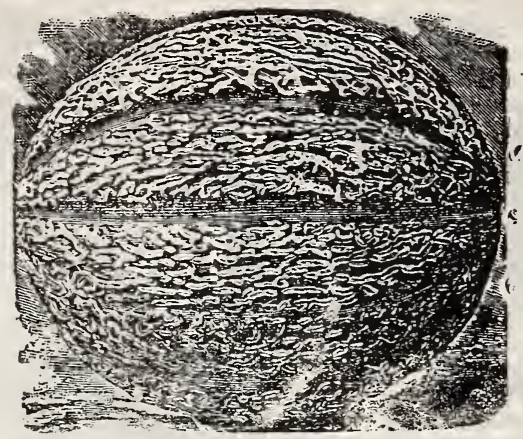

LANG'S GOLD-LINED NETTED ROCK

ALABAMA SWEET.-This is a large, oblong melon; color dark green with faint lighter stripes. Fancy selected Southern grown seed. Pkt., 5c; oz., $10 \mathrm{c} ; 1 / 4 \mathrm{lb}$., $25 \mathrm{c}$; lb., $85 \mathrm{c}$. KLECKLEY SWEETS.-Vines strong and vigorous. Pkt., 5c; oz., $10 \mathrm{c} ; 1 / 4$ lb., 25c; 1 b., $85 \mathrm{c}$.

GEORGIA RATTLESNAKE.-Standard Southern variety oblong, flesh scarlet, crisp and juicy. A good shipper. Pkt., $5 \mathrm{c}$; oz., $10 \mathrm{c}$; $1 / 4 \mathrm{lb}$., 25c; $1 \mathrm{~b}$., $85 \mathrm{c}$.

CITRON-Grows uniformly round and smooth, striped and marbled with light green. Flesh white and solid, seeds red. This sort is not used for eating in the raw state, but for preserves and pickles, etc. Pkt., 5c; oz., 10c; $1 / 4$ lb., $25 \mathrm{c}$ lb., 85c.

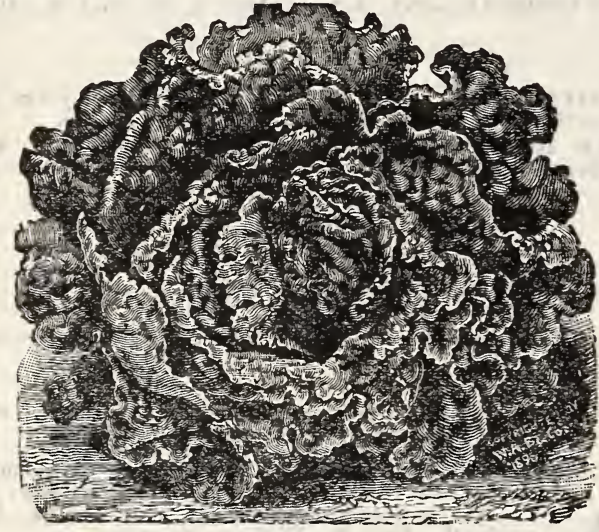

PRIZEHEAD

\section{Lettuce}

LANG'S CALIFORNIA MAMMOTH.-This is by far the best lettuce we have introduced for the market gardener. Pkt., 5c; oz., 15c; $1 / 4$ lb., $45 \mathrm{c}$; lb., $\$ 1.50$.

BIG BOSTON.-One of the most valuable varieties for open ground or forcing in cold frames. Pkt., 5c;0z., 10c; $1 / 4 \mathrm{lb}$., $35 \mathrm{c} ; \mathrm{lb}$., $\$ 2.50$.

PHILADELPHIA BUTTER.-This is one of the finest, the most brittle as well as the crispest Lettuce. Pkt., 5c; oz., $10 \mathrm{c} ; 1 / 4 \mathrm{lb}$., 30c; lb., $\$ 1.00$.

HANSON.-One of the finest. Heads very large, solid, tender, crisp and of excellent flavor. Stands the sun and drought better than most varieties. Pkt., 5c; oz., 10c; 1/4 lb. $30 \mathrm{c} ; 1 \mathrm{~b}$., \$1.00.

EARLY CURLED SIMPSON-(Seed white). Leaves light green, slightly frilled, crisp, sweet and tender. Pkt., 5c; oz., $10 \mathrm{c} ; 1 / 4 \mathrm{lb}$., 30c; lb., \$1.00.

MAY KING.-A handsome, light green heading variety of medium size and excellent quality. Pkt., 5c; oz., 10c; 1/4 lb., $30 \mathrm{c} ; \mathrm{lb}$., $\$ 1.00$.

PRIZEHEAD.-Forms large, loose heads, which will not stand shipment to distant markets. Pkt., 5c; oz., 10c; 1/4 lb., $30 \mathrm{c}$; lb., $\$ 1.00$.

BROWN DUTCH.-A valuable fall and winter variety, standing almost any amount of cold. Pkt., $5 \mathrm{c} ;$ oz., $10 \mathrm{c} ; 1 / 4 \mathrm{lb}$., $30 \mathrm{c} ; 1 \mathrm{~b} ., \$ 1.00$.

\section{Honey Dew Melons}

HONEY DEW MELON.- The Honey Dew Melon produces a melon with a smooth almost white rind, measuring about six inches in diameter, about seven inches long. The green flesh is thick and has a peculiar sweet flavor, somewhat like a banana; they are at their best when a little over-ripe. Pkt., 10e; oz., 15e; 1/4 1b., 35e; Ib., \$2.00.

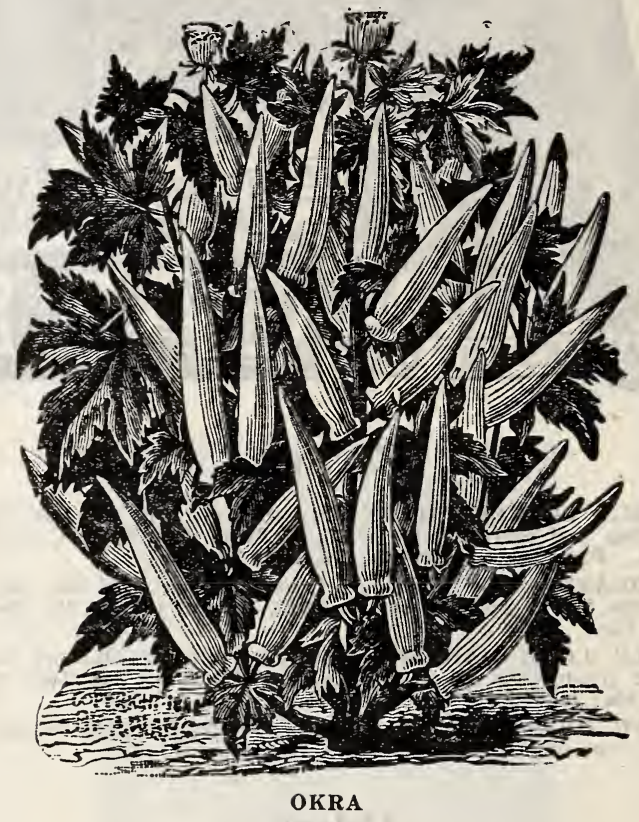

\section{Okra}

TALL GREEN.-Long, slender pods, light colored; keep edible a long time and are very tender. Pkt., 5c; oz., 10c; $1 / 4$ lb., 15e; lb., 75e.

WHITE VELVET OKRA.-It is distinct in appearance, the pods are perfectly round, smooth, of an attractive white velvety appearance, and of superior flavor and tenderness. Pkt., 5e; oz., 10e; $1 / 4$ lb., 15e; lb., 75e.

DWARF GREEN.-Early and productive, smooth pods. Oz., 5e; $1 / 4$ 1b., 15e; 1b., 75c.

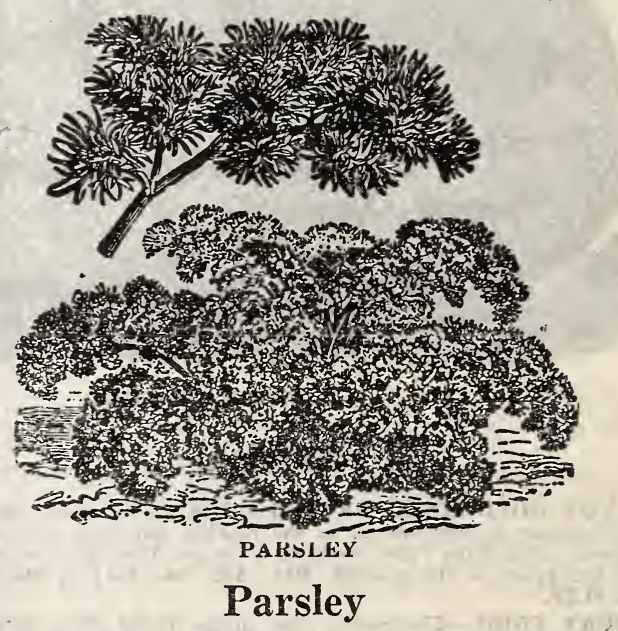

CHAMPION MOSS CURLED.-A very select stock; the leaves are curled and crimped. Pkt., 5c; oz., 10c; $1 / 4 \mathrm{lb}$., $35 \mathrm{c}$; lb., \$1.25, postpaid.

PLAIN PARSLEY.-Dark green leaves, good for seasoning. Pkt., 5c; oz., 10c; 1/4 lb., 35c; lb., \$1.25, postpaid. 


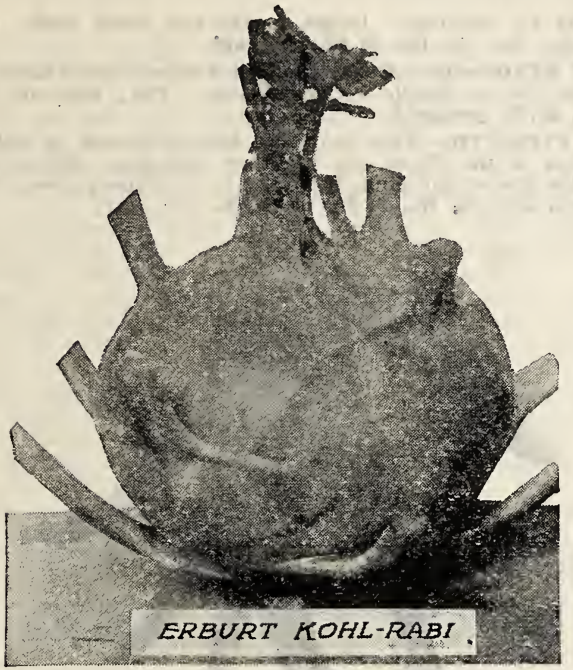

\section{Kohl-Rabi (Kohlrabi)}

EARLY WHITE VIENNA.-Flesh white and tender: a standard sort for market and table use. Pkt., 10c; oz., $20 \mathrm{c} ; 1 / 4 \mathrm{lb}$., 50c.

EARLY PURPLE VIENNA-Differs from the Early White Vienna in color only. Pkt., 10c; oz., 20c; $1 / 4$ lb., 50c.

\section{Parsnips}

HOLLOW CROWN.-A standard sort. Pkt., 5c; oz., 15c : X/4 lb., 35c; lb., \$1.25.

\section{Kale or Borecole}

DWARF GREEN.-A finely curled, spreading, low-growing variety, very hardy, and the favorite sort sown in the South for winter greens. Pkt., 5c; oz., 15c; $1 / 2$ lb., 50c; lb., \$1.75.

\section{Mustard}

SOUTHERN GIANT CURLED.-The best for greens and the most popular mustard in the South. None better. Pkt., 5c: oz., $10 c$; $1 / 4$ lb., 20c; 1b., 65c.

OSTRICH PLUME-Dark green leaves curve outwardly like an ostrich plume. Pkt 5c: 0z, 10c: 1/4 lb 20c: lb $65 \mathrm{c}$ LARGE SMOOTH LEAVED.-Has a large, fleshy leaf. This variety fills a long-felt want in the South. Pkt., 5c; oz. $10 \mathrm{c} ; 1 / 4 \mathrm{lb} ., 20 \mathrm{c} ; 1 \mathrm{~b} ., 65 \mathrm{c}$.

WHITE.-A small pungent salad. The seed is also used for flavoring pickles, etc. Price, pkt., 5c; oz., $10 \mathrm{c}$; $1 / 4 \mathrm{lb}$. $25 \mathrm{c}$; lb., 80c.

\section{Potatoes}

IRISH COBBLER POTATO.-A comparatively new and very fine early variety; extensively grown for market in some localities. This is a very reliable variety and heavy cropper. PURE EARLY ROSE.-The good old favorite which continues in great popularity. The seed we offer is the purest and best that can be put on the market.

TENNESSEE TRIUMPH-Matures a week in advance of the Early Rose. Color a beautiful light red.

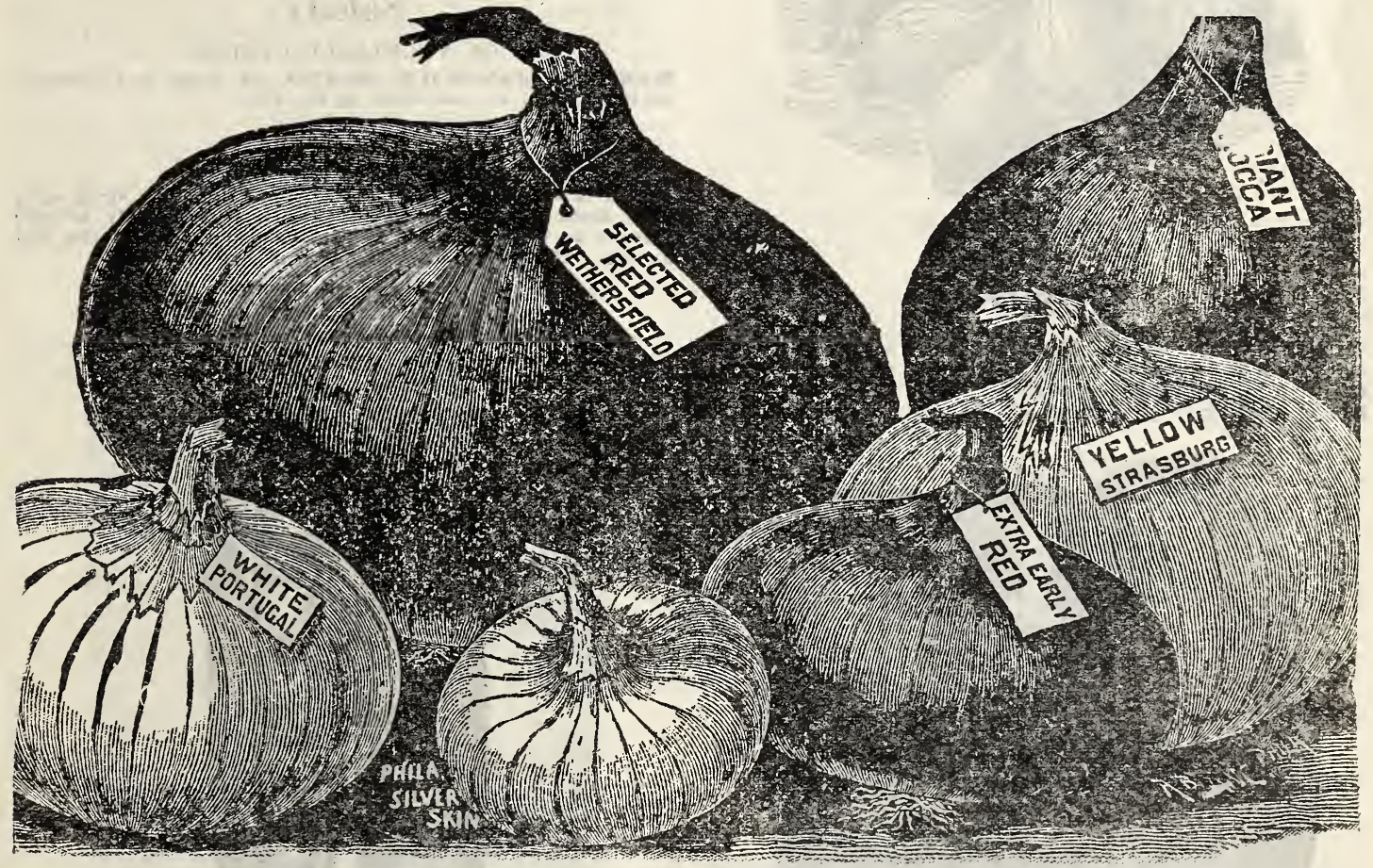

\section{Onions-New Crop Seed}

CRYSTAL WAX BERMUDA.-The most attractive onion in the world. Pkt., 10c; oz., 75c; $1 / 4$ lb., $\$ 2.50 ; 1 b ., \$ 6.00$. IMPORTED RED BERMUDA.-Our genuine Red Bermuda is a favorite for home use. Pkt., 10c; oz., 25c; 1/4 lb., $\$ 1.00$, lb., $\$ 3.75$.
IMPORTED YELLOW BERMUDA.-Planted extensively by market gardeners in the South for shipping. Pkt., 10c; oz. 25 ; $1 / 4$ lb., $\$ 1.00 ; 1 b ., \$ 3.75$.

WHITE PEARL, EXTRA EARLY.-The earliest of all the white varieties, If you are in want of an early white onion, grow Extra Early Pearl. Its immense yield and fine quality will please you. Pkt., 10c; oz., 35c; $1 / 4$ lb., $\$ 1.00$; $1 \mathrm{~b}$., $\$ 3.75$. 
THE MAMMOTH SILVER KING.-This variety has been extensively cultivated in all sections for the past five years and has given perfect satisfaction. Pkt., 10c; oz., 35c; $1 / 4$ lb., \$1.25; lb., \$4.00, post paid.

GIANT YELLOW PRIZETAKER.-Extra large size onion, particularly fine flavor. Pkt., 10c; oz., $30 \mathrm{c}$; $1 / 4 \mathrm{lb}$., $\$ 1.00$; lb., $\$ 3.75$, postpaid.

YELLOW GLOBE DANVERS.-This strain of Globe Danvers is equal to any usually sold and may be relied upon as a first-class cropper in every way. Pkt., 10c; oz., 30c; $1 / 4$ lb., $\$ 1.00 ; 1 b ., \$ 3.75$, postpaid.

LARGE RED WEATHERSFIELD.-The most widely cultivated red variety, the standard winter onion in many Northern states. A most excellent keeper. Pkt., 10c; 0z., 35c; $1 / 4$ lb., $\$ 1.00$; lb., $\$ 3.75$, postpaid.

AUSTRALIAN BROWN.-Of medium size, wonderfully hard and solid; ripens very early; a fine keeper. Pkt., 10c; oz., $35 \mathrm{c} ; 1 / 4 \mathrm{lb}$., $\$ 1.00 ; 1 \mathrm{~b} ., \$ 3.50$, postpaid.

\section{Onion Sets}

ONIONS SETS.-Onion sets should be planted out as soon as the ground is in condition to work, early in the spring. Notice: Prices by the bushel are subject to fluctuation of this market, but the prices quoted on quarts will hold good throughout the season, or as long as our stock allows.

WHITE BOTTOM.-Qt., 35c, postpaid.

RED BOTTOM.-Qt., 35c, postpaid.

YELLOW BOTTOM.-Qt., 35c, postpaid.

Write for prices on larger quantities.

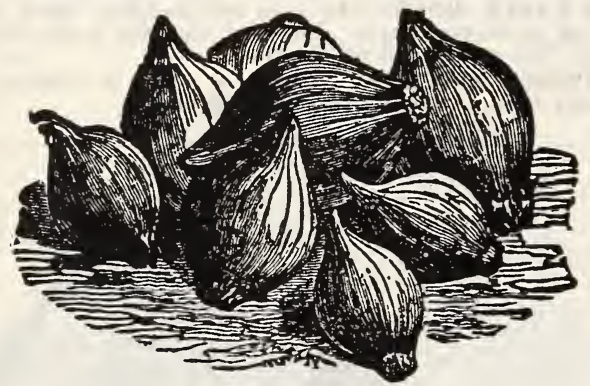

PICKLING ONIONS

\section{Peppers}

CHINESE GIANT.-The largest and most handsome Pepper in the world, twice the size of its nearest rival. Pkt., 10c; oz., 50c; $1 / 4$ lb., $\$ 2.00$, postpaid.

BELL or BULL NOSE.-Early and of mild flavor. A

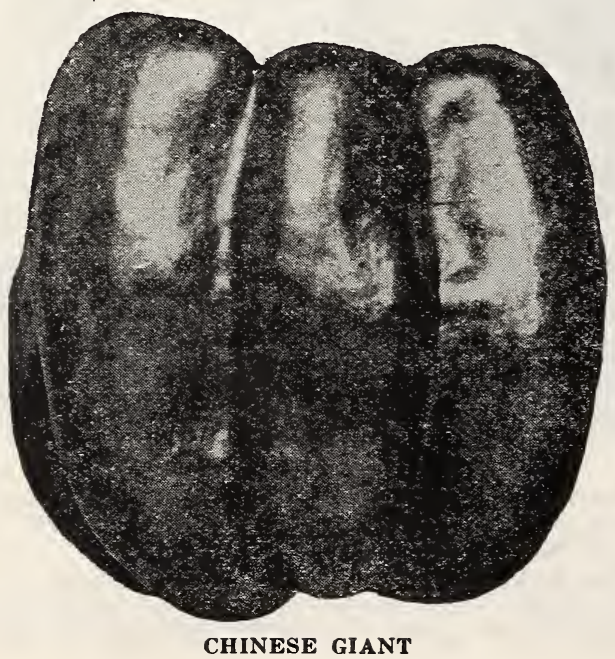

favorite for pickling. Large, bright red, thick flesh. Pkt., 10c; oz., 50c; $1 / 4$ lb., $\$ 1.60$, postpaid.

RUBY KING.-One of the standard Peppers, very large and of mild flavor. Bright ruby red color. Pkt., 10c; oz., 50c; $1 / 4$ lb., $\$ 1.60$, postpaid.

NEW PIMENTO.-This pepper is largely grown in California, also in the South, for canning purposes. When ready for table use or shipping, the color is a brilliant green. Pkt., $10 \mathrm{c}$; oz., 50c; $1 / 4 \mathrm{lb}$., $\$ 1.60$, postpaid.

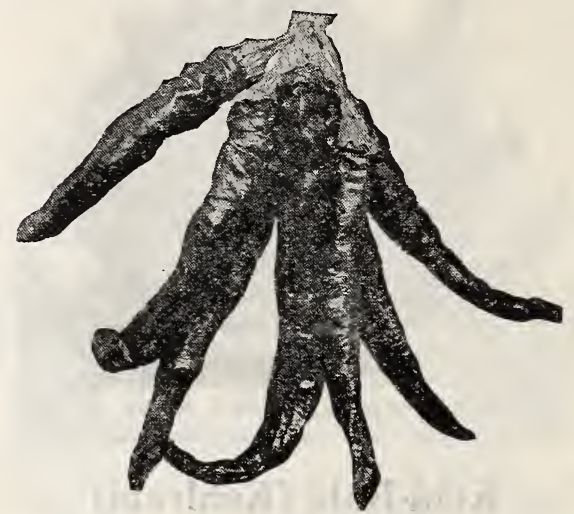

PEPPERS, RED CAYENNE

LONG RED CAYENNE.-Of dwarf growth, bearing long, pungent pods. Pkt., 10c; oz., 50c; $1 / 4$ lb., \$1.60, postpaid. RED CHILI.-Smaller and later than Cayenne. Extensively used for pepper sauce. Pkt., 10c; oz., 50c; 1/4 lb., \$1.60, postpaid.

\section{Salsify}

OR VEGETABLE OYSTER.

MAMMOTH SANDWICH ISLAND.-A large and superior variety. Pkt., 5c; oz., 15c; $1 / 4$ lb., 45c.

\section{Peas}

FIRST AND BEST.-A vigorous growing, hardy, extra early sort, about $2 \frac{1}{2}$ feet in height, unbranched, usually bearing from 5 to 7 pods each, filled with smooth peas of the best quality. Pkt., 10c; lb., 30c; 2 lbs., 55c, postpaid.

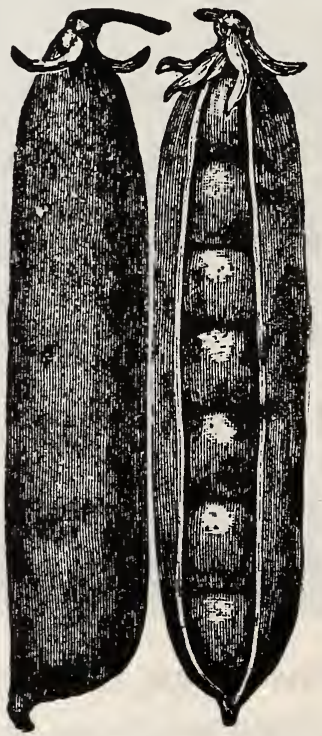

PRIDE OF THE MARKET

ALASKA.-This is a smooth blue pea of unequalled evenness in growth of vine and early maturity of pods, well 
filled with medium size, bright green peas of excellent flavor. Pkt., 10c; 1b., 30c; 2 lbs., 55c, postpaid.

LAXTONIAN. - This very handsome wrinkled pea is the largest podded of the dwarf varieties on our list. Pkt., 10c: lb., $40 \mathrm{c}$; 2 lbs., 75c, postpaid.

AMERICAN WONDER.-Until the introduction of Nott's Excelsior this was the earliest of all the wrinkled varieties. It is of dwarf habit, only grows about 10 to 12 inches high, but always produces a profusion of well filled pods of the richest flavor. Our stock is selected with the greatest care. Pkt., $10 \mathrm{c}$; lb., 35c; 2 lbs., $65 \mathrm{c}$, postpaid.

PRIDE OF THE MARKET.-Vines of medium height, stiff, with large dark green leaves and bearing at the top, generally in pairs: a good crop of large, pointed, dark green pods. Pkt., 10c; lb., 35c; 2 lbs., 65c, postpaid.

BLISS' EVERBEARING. - Height of vines, two feet; foliage very large, firm and bright green; pods three to four inches long. Pkt., 10c; lb., 35c; 2 lbs., 65c, postpaid.

CHAMPION OF ENGLAND. - The favorite late variety. Pkt., $10 \mathrm{c}$; lb., 35c; 2 lbs., 65c, postpaid.

THOMAS LAXTON.-A very early wrinkled variety of great merit. The vines are vigorous, of medium height, about three feet. Pkt., 10c; lb., 40c; 2 lbs., 75c, postpaid.

NOTT'S EXCELSIOR.-Grows 15 inches high, and is claimed by the introducer to be the earliest and best Dwarf Wrinkled Pea ever introduced. For the home garden it cannot be too highly recommended. Pkt., $10 \mathrm{c} ; 1 \mathrm{~b} ., 35 \mathrm{c} ; 2$ lbs., $65 \mathrm{c}$, postpaid.

LARGE WHITE MARROWFAT.-The vines of this variety are about 5 feet high and of strong growth. Pkt., 10c; lb., 30c; 2 lbs., 55c, postpaid.

NEW TELEPHONE.-Seed green, wrinkled; height about 4 feet. Pkt., 10c; lb., 35c; 2 lbs., 65c, postpaid.

\section{Pumpkins}

CONNECTICUT FIELD.-A very productive old standard sort that is grown almost exclusively for stock feeding purposes. Pkt., 5c; oz., 10c; $1 / 4$ lb., 25c; lb., 85c, postpaid.

IMPROVED GREEN-STRIPED CUSHAW.-A crook-necked variety, with green and white striped skin. The flesh is of rich yellow color, solid, fine grained, very thick and sweet. Pkt., 5c; oz., 15c; $1 / 4$ lb., 45c; lb., $\$ 1.75$.

LARGE CHEESE or KENTUCKY FIELD.-Very popular and productive. Flesh yellow, thick, tender, nutritious and of excellent quality. Pkt., 5c; oz., 10c; $1 / 4$ lb., 25c; 1b., 85c. TENNESSEE SWEET POTATO.-The best variety for home gardens. They are almost pear-shaped, growing to a large size. Vines are enormously productive. Pkt., 5c; oz., 15c; $1 / 4$ lb., $40 \mathrm{c}$; lb., $\$ 1.65$.

\section{Rhubarb}

VICTORIA.-The finest market variety, producing large thick, heavy stalks in rich soil. Pkt., 5c; oz., 20c; 1/4 1b., 50c.

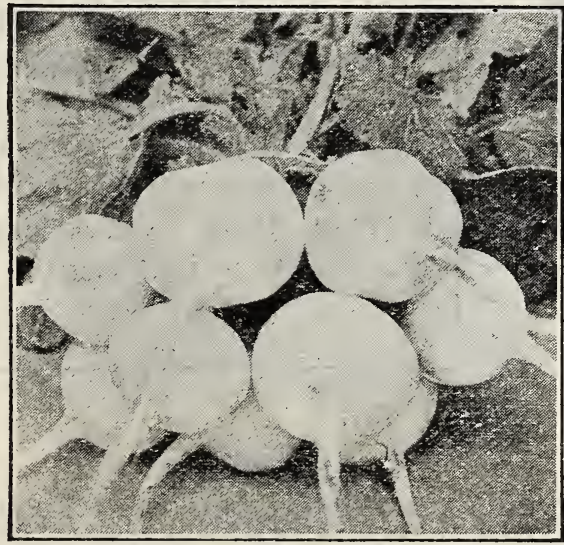

RADISHES, WHITE TURNIP

\section{Radishes}

EARLY SCARLET TURNIP.-A round, red, turnip-shaped radish with small tops and of very quick growth. Very desirable for early outdoor planting, as well as foreing. Pkt., 5c; oz., 10c; $1 / 4$ lb., 25c; lb., 85c.

EARLY SCARLET TURNIP, WHITE TIPPED.-One of the handsomest of the turnip radishes and a great favorite in many large markets for early planting outdoors. Color very

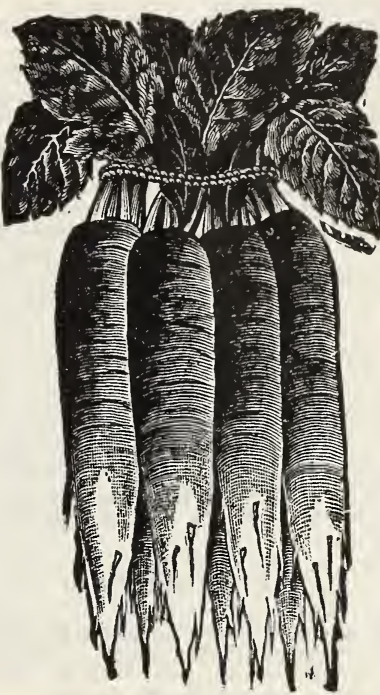

LONG SCARLET RADISH

deep scarlet with a distinctly white tip. Pkt., 5c; oz., 10c; $1 / 4$ lb., 25c; lb., 85c.

FRENCH BREAKFAST.-A quick growing, small, oliveshaped radish about $11 / 2$ inches long by $5 / 8$ to $8 / 4$ of an inch in diameter when fully grown. Color beautiful deep scarlet except a little clear white about the tip. Pkt., 5c; oz., 15c; $1 / 4$ lb., 35c; lb., 85c.

ROSE CHINA WINTER.-One of the best fall radishes; a favorite with market gardeners. Pkt., 5c; oz., 10c; $1 / 4$ lb. $35 \mathrm{c} ; 1 \mathrm{lb.}$, \$1.25.

CHARTIER.-The color at the top is a bright crimson, changing to a pink at the center and from thence downward it is a pure waxy white. Pkt., 5c; oz., 10c; 1/4 lb., 35c; lb., \$1.25.

LONG SCARLET SHORT TOP.-The standard long variety for market and home gardens; root long and growing partly above ground. Pkt., 5c; oz., $10 \mathrm{c}$; $1 / 4 \mathrm{lb}$., $25 \mathrm{c}$; lb., $85 \mathrm{c}$.

LONG WHITE VIENNA or LADY FINGER.-This is one of the finest long radishes, beautiful in shape, skin and flesh pure white. Pkt., 5c; oz., 10c; 1/4 lb., 25c; lb., 85c.

ICICLE.-The earliest and finest long white radish. Pkt., 5c; oz., $10 \mathrm{c}$; $1 / 4 \mathrm{lb}$., $25 \mathrm{c}$; $1 \mathrm{~b}$., $85 \mathrm{c}$.

ROUND BLACK SPANISH.-Skin black, flesh white; roots round ; well flavored. Keeps well through the winter. Plst. $5 \mathrm{c} ; 0 z ., 15 \mathrm{c} ; 1 / 4 \mathrm{lb} ., 40 \mathrm{c}$; lb., $\$ 1.25$.

LONG BLACK SPANISH.-One of the latest and hardiest long radishes, especially adapted for winter use. Roots rather long, thick, almost black, with white flesh. Pkt., 5c; oz., 15c; $1 / 4$ lb., 40c; lb., \$1.25.

\section{Turnip}

EXTRA EARLY PURPLE TOP MILAN,-Fully a week earlier than any variety. Pkt., 5c; oz., 15c; $1 / 4$ lb., 60c; lb., $\$ 2.00$.

PURPLE TOP FLAT STRAP LEAF.-The standard variety. Pure white, except the purple outer skin above the ground. Pkt., 5c; oz., 10c; 1/4 lb., 20c; lb., 65c.

PURPLE TOP WHITE GLOBE.-This famous purple top turnip is very desirable for home gardens, and a favorite 
with market gardeners on account of its shape, size and beauty. Flesh pure white, with a red or purple top. Pkt., $5 c$; oz., $10 \mathrm{c} ; 1 / 4$ lb., 20c; lb., 65c.

WHITE GLOBE.-The king of all mammoth white Turnips. A very good autumn variety. Pkt., 5c; oz., 10c; 1/4 lb., 20c; lb., 65c.

WHITE EGG.-A very quick growing Fall Turnip. Should be sown in August. Oval or egg-shaped, flesh very firm and fine grained; flavor mild and sweet. A fine cooking variety. Pkt., 5c; oz., 10c; 1/4 lb., 35c; lb., $\$ 1.25$.

EARLY WHITE FLAT DUTCH.-A popular, well-known early sort; the best variety for spring sowing. Pkt., 5c; oz., $10 \mathrm{c} ; 1 / 4 \mathrm{lb} ., 25 \mathrm{c}$; lb., $90 \mathrm{c}$.

AMBER GLOBE.-Yellow flesh, firm, fine grain; very sweet; skin yellow, with green top; keeps well; very popular in the South. Pkt., 5c; oz., 10c; 1/4 1b., 25c; lb., 75c.

GOLDEN BALL.-Rapid grower, globe-shaped and of a deep yellow color. Pkt., 5c; oz., 10c; $1 / 4$ lb., 20c; lb., 65c.

SEVEN TOP.-Grown only for the tops, which are used for greens or salad in the South. Pkt., 5c; oz., 10c; 1/4 lb., 20c; lb., 65 c.

\section{Rutabaga}

AMERICAN YELLOW PURPLE TOP.-The most satisfactory variety of Rutabaga to grow for either family use or stock feeding. Is very hardy and productive. Flesh yellow, solid and sweet. Pkt., 5c; oz., 10c; 1/4 1b., 25c; lb., 75c. COWV HORN.-Long white, resembling a cow horn; good for winter. Pkt., 5c; oz., 10c; 1/4 lb., 35c; lb., \$1.00.

\section{Tomatoes}

BEAUTY.-Of a very glowing crimson in color and with a slight tinge of purple. It has more solid flesh and fewer seeds than average kinds and is less inclined to rot. Pkt., 5c; oz., 30c; 1/4 lb., \$1.25; lb., $\$ 4.00$.

ACME.-The old standard variety. The color is a crimsontinted, with a light pinkish shade. Our seed is selected. Pkt., 5c; oz., 25c; $1 / 4$ lb., $\$ 1.00 ;$ lb., $\$ 3.50$.
SPARK'S EARLIANA.-This tomato has become very popular with many growers of tomatoes for early market. Pkt., 5c; oz., 35c; $1 / 4$ lb., 85c; lb., $\$ 3.25$.

JUNE PINK TOMATO.-The earliest pink tomato. Pkt., $5 c$; oz., 35c; $1 / 4$ lb., $\$ 1.10$; lb., $\$ 4.00$.

NEW STONE.-Fruit large and deep, bright scarlet; smooth, ripening evenly to the stem without a crack; very solid and firm fleshed; of the finest quality. Pkt., 5c; oz., 25c; 1/4 lb., $75 \mathrm{c}$; lb., $\$ 2.50$.

McGEE.-This variety was introduced three years ago, and gave excellent success. The most prolific bearer. The color is a bright crimson, very solid and of good flavor, producing few seeds and small cavities. A variety that can be depended on both for market and home use. Pkt., 10c;0z., 45c; 1/4 lb. $\$ 1.00$; lb., $\$ 3.75$.

PERFECTION.-Preferred by many to any other sort, and is extensively grown by gardeners who raise fruit for the canning factories. It is invariably smooth and of a handsome deep blood red; flesh is thick; almost coreless. Pkt., 5c; oz., $30 \mathrm{c}$; $1 / 4$ lb., 85c; lb., $\$ 3.00$.

GOLDEN QUEEN.-Fruits large and smooth; color a beautiful golden yellow, sometimes with a slight blush of red, as smooth and well shaped as the best of the red varieties and of superior flavor. Plst., 10c; oz., 50c; 1/4 lb., $\$ 1.75$; lb., $\$ 6.00$.

YELLOW PEAR.-A pear-shaped variety, used for preserving. Vines are very heavy yielders. Pkt., 5c; oz., 35c ; $1 / 4$ lb., $\$ 1.50$.

\section{Squash}

EARLY WHITE SCALLOPED BUSH.-A beautiful white Squash of light cream color, large size, flat. Elegant for home use. Pkt., 5c; oz., 10c; 1/4 lb., 30c; lb., \$1.50.

\section{Spinach}

CURLED BLOOMSDALE or LONG STANDING SPINACH.Produces nearly twice the weight of crop as other varieties and has further merit in the fact that it is the hardiest of all varieties of spinach. Pkt., $5 \mathrm{c} ; 0 \mathrm{z} ., 10 \mathrm{c} ; 1 / 4 \mathrm{lb}, 15 \mathrm{c} ; \mathrm{lb} ., 40 \mathrm{c}$.

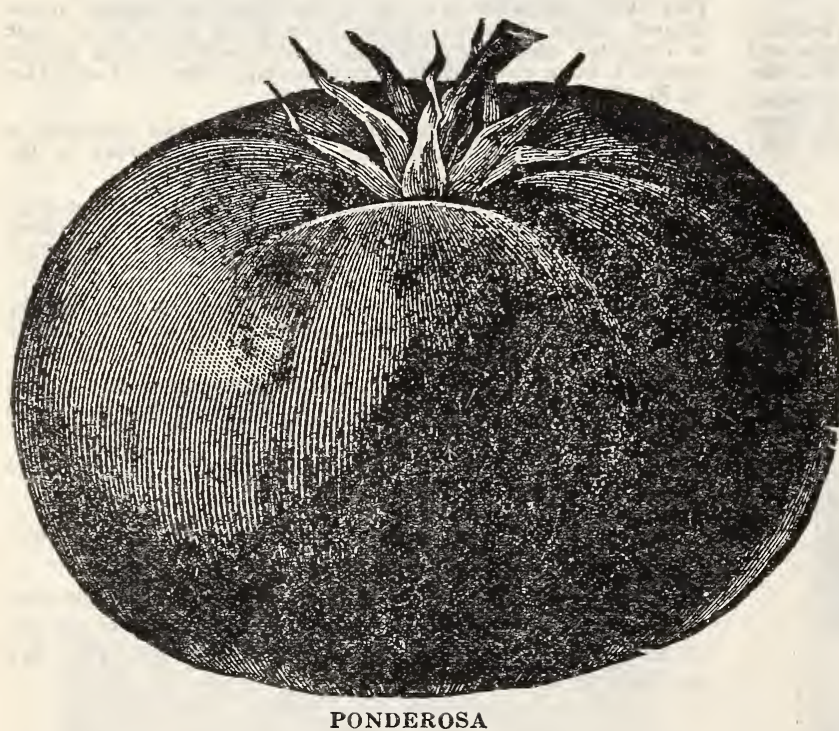

PONDEROSA

\section{$\$ 3.50$ Rose Special}

\section{. 12 Roses, 2 Yeats Old}

\section{Twelve large field-grown} roses, at least six varieties, our selection, all colors-a beautiful bed of toses at less than one-half tegulat prices. Plant a mixed tose bed and see the beauty.
DWARF CHAMPION.-The best early tomato grown; entirely distinct in habit of growth and foliage; vines are dwarf and compact, grow stiff and upright, with thick, short jointed stems. Plt., 5c; oz., 30c; 1/4 lb., \$1.25; lb., \$4.00. LIVINGSTON'S DWARF STONE.-In habit of vine it resembles Dwarf Champion, but is of stronger growth and more erect. Pkt., 5c; oz., 40c; $1 / 4$ lb., \$1.25; lb., \$4.00.

PONDEROSA.-This is one of the largest varieties. The fruits are of a purplish pink color; very solid and ripen early, continuing to do so until frost. Pkt., 10c; oz., 45c; $1 / 4$ lb., $\$ 1.40$; lb., $\$ 5.00$.

\section{Herbs}

CHERVIL.-For flavoring soups, etc. Pkt., 5c; oz., 15c. DILL.-Seeds for flavoring pickles and vinegar. Pkt., 5c ; oz., 10c.

MAR.JORAM, SWEET.-For seasoning. Pkt., 5c; oz., 25c MUSTARD, WHITE.-For seasoning. Oz., 10c; lb., 75c. SAGE.-Used as a culinary herb, also for fowls. Pkt., 10c ; oz., 25c.

THYME.-Used as a seasoning. Pkt., 5c.

SWEET BASIL.-Used for flavoring soups and sauces. Plat., 10c. 


\section{Fresh, New and Reliable Flower Seed}

NOTICE TO FLOWER SEED BUYERS: WE MAKE A SPECIALTY OF ALL THE LEADING SEEDS. IF YOU WANT TO BEAUTIFY YOUR PLACE AT A SMALL COST, TRY OUR SEEDS. NOTE THE RESULTS.

ALL PACKet SEeds ARE PREPAid.

\section{Alyssum, Sweet}

The delicate, honey-like fragrance of its white flowers is much prized in bouquets and baskets.

Little Gem.-The best variety for bedding. Very dwarf and compact. Pkt., 10c.

\section{Alyssum Benthami}

Trails; white and fragrant. Pkt., 10c.

\section{Amaranthus}

Brilliant foliage annuals, bearing curious racemes of flowers.

Caudatus (Love Lies Bleeding).-Blood red; drooping. Pkt., $10 \mathrm{c}$

Tricolor (Joseph's Coat).-Leaves red, yellow and green. Pkt., 10c.

\section{Aquilegia}

\section{(Columbine)}

Beautiful, curiously formed and variously colored flowers. Double.-All colors mixed. A beautiful yard plant and good bloom; all colors imaginable. Pkt., 10c.

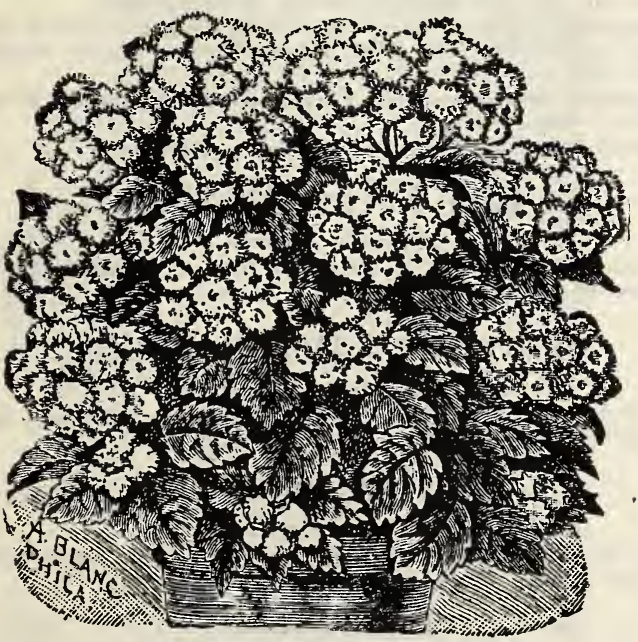

AGERATUM

\section{Ageratum}

'This plant is almost constantly in bloom throughout the summer.

Mexicanum.-Lavender-blue. 2 feet. Pkt., 10c.

Tom Thumb.-Mixed, rarely exceeds 6 inches in height. Pkt., 10c.

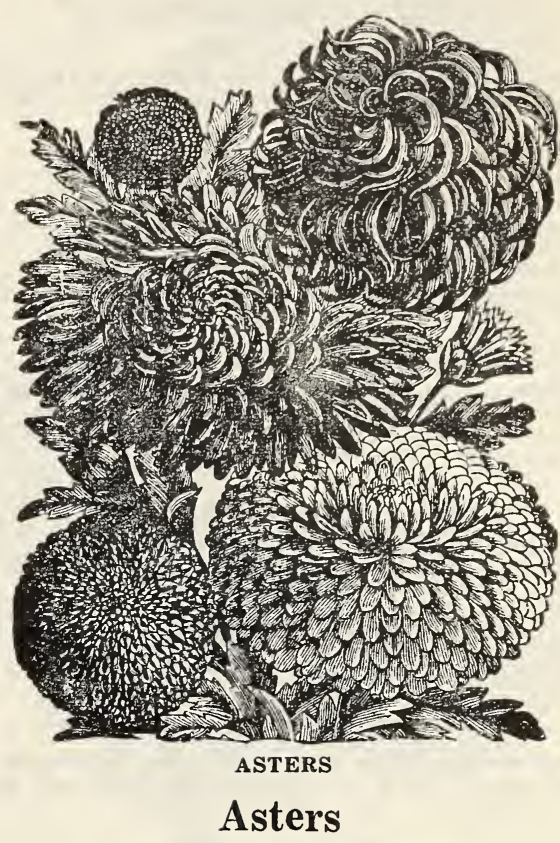

One of the prettiest mid-summer flowering plants. Asters.-All "colors mixed. Pkt., 10c.

Asters, Delicata.-Light pink. Pkt., 10c.

Asters, Peony.-All colors mixed. Pkt., 10c.

Asters, Empress of China.-Dark blue. Pkt., 10c.

Asters, Fire King.-Deep crimson. Pkt., 10c.

Asters, Snowball.-Pure white. Pkt., 10c.

\section{Carnations}

Carnations are general favorites.

Marguerite.-Variety of colors and delicious perfume will insure its popularity in all gardens where cut flowers are in demand. Pkt., 15c.

Finest German.-Mixed colors ; saved from extra fine, double, named flowers. Pkt., 25c.

Double Vienna.-Dwarf; early; large flowers; all colors and beautiful markings. Pkt., 15c.

\section{Balsam}

(Lady Slipper)

An old favorite garden flower. Rose Flowering.-Mixed. Pkt., 10c. Double Dwarf Mixed.-Pkt., 10c.

\section{Burning Bush or Summer Cypress} (Kochia Trichophila)

This we consider one of the most ornamental border or hedge plants that has ever been brought out and it is sure to attract attention. Pkt., 10c.

\section{Candytuft}

Universally known and cultivated and considered indispensable for cutting.

White Rocket.-Pkt, 10c.

Dwarf Mixed.-Pkt., 10c.

\section{Celosia}

(Coxcomb)

Glasgow Prize.-The best dwarf crimson sort, with handsome dark foliage. Combs very large and solid. Pkt., 10c. 
Plumosa (Plumed or Ostrich Feather Cockscomb).-Blooming in late summer and autumn. Producing large, showy plumes resembling ostrich feathers. Pkt., 10c.

\section{Chinese Wallflower}

\section{(Celosia Childsii)}

This novelty has proved a great success everywhere. The most odd and novel flower of most any garden. Pkt., 10c.

\section{Centaurea}

\section{(or Bachelor's Button)}

Thanks to the praiseworthy fashion of using only longstemmed flowers for bouquets, the different species of Centaurea have become general favorites in all countries.

Bachelor's Button (Centaurea Cyanus).-Called Blue-Bottle, Ragged Soldier, etc. Mixed colors. Pkt., 10c.

Imperialis (Giant Sweet Sultan). $-2 \frac{1}{2}$ feet. Finest of all Sweet Sultans for cut flower purposes. Pkt., 10c.

Candidissima-Ornamental Leaved Centaurea (Dusty Miller).-For bedding, hanging baskets and pots and for edging of beds where white basket foliage is desired. Silvery white, finely cut leaves. One foot. Pkt., 10c.

\section{Calendula}

Large double flowers, blooming all summer. Meteor.-Creamy center, edged with orange. Pkt., 10c.

\section{Castor Oil Beans}

Blood-red stalks and clusters of red fruit. Eight feet. Pkt., 5c.

\section{Chrysanthemums}

Mixed annual. These varieties are summer-flowering sorts and are greatly prized for their brilliant colors and profuse blooming qualities. Pkt., 10c.

\section{Coreopsis}

\section{(Grandifiora)}

Large, showy, bright yellow flowers. Easily grown from seed, flowering the first year if sown early. Pkt., 10c.

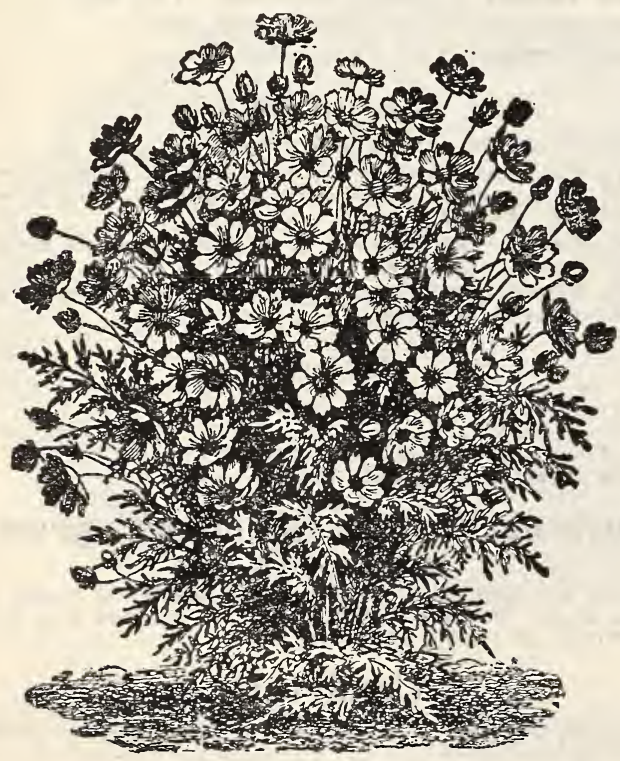

Cosmos

\section{Cosmos}

The flowers are borne profusely in loose clusters, and present a charming appearance. Pkt., 10c.

Klondyke Cosmos (Orange)-15c Pkt.

\section{Canna}

Cannas are famous for their luxuriant growth and immense Gladiolus-like flowers of most brilliant colors.

Large-Flowering French Hybrid.-Early flowering and remarkable for large size and beauty of flower and foliage. This elegant collection contains everything that is best in Cannas. Large pkt., 10c.

Madame Crozy (Dwarf).-Flowers beautiful scarlet with gold border around each petal; foliage green. Pkt., 10c.

\section{Dahlia}

Double, Finest Mixed.-Large flowering. Pkt., 10c. Single Mixed.-Large, showy single flowers. Pkt., 10c.

\section{Daisies}

Daisy, Double Perennial Mixed (Bellis)-Will bloom the first season if sown early. Pink, white and red. Pkt., 10c.

Marguerite or Paris.-One of the best known and most popular plants, both for house and yard. Pkt., 10c.

Shasta Daisies.-A great improvement upon the old-fashioned daisy, being about 2 or 3 inches in diameter. Very fine. Pkt., 25c.

\section{Digitalis}

$$
\text { (Foxglove) }
$$

Gloxinia-shaped flowers. A lovely type. All colors mixed. Pkt., 10c.

\section{Everlasting Flowers}

Mixed Everlasting.-A good variety; all the useful and favorite sorts. Pkt.. 10c.

Globe Amaranth or Bachelor's Buttons, Mixed.-Two feet high, producing small, globe-shaped, double flowers in bright colors. Pkt., 10c.

\section{Four o'Clock}

\section{(Marvel of Peru)}

Blooming the first season from seed. The flowers, which are produced in clusters, open in the afternoon. Pkt., 10c.

\section{Dianthus or Pinks}

Double annual varieties. A magnificent genus, embracing some of the most popular flowers in cultivation.

Heddewigi (Japan Pink).-Colors vary from the richest velvety crimson to the most delicate rose. Double mixed. Pkt., 10c.

Imperials (Double Imperial Pink).-Double variegated. Mixed colors. Pkt., 10c.

Double China.-Beautiful full flowers. Pkt., 10c.

\section{Blue Forget-Me-Not}

(Myosotis Alpestris)

An old favorite. It flourishes best in a moist, shady situation. Pkt., 10c.

\section{Feverfew-Double White}

\section{(Matricaria)}

For cutting and pot culture, as well as for beds and borders. Pkt., 10c.

\section{Gypsophila \\ (Bahy's Breath)}

Delicate. free-flowering plants covered with star-shaped flowers. Pkt., 10c.

\section{Geraniums}

All the leading fine varieties are combined in this mixture. Pkt., 25c.

\section{Heliotrope}

Everyone loves the delightful fragrance and beauty of the Heliotrope. It can be raised from seed as easily as Verbenas. Fine mixed. Pkt., 10c.

\section{Hollyhocks}

Few plants combine as many good qualities or lend them. selves as readily to varied uses as hollyhock. Extra choice double mixed. Pkt., 10c. 


\section{Ice Plants}

The most suitable plant grown for hanging baskets ; leaves of dark green and glossy color hanging down one to two feet. Pkt., 10c.

\section{Kochia}

(Mexican Fire Bush)

Pretty ornamental plant with fine, feathery foliage; light green, turning to blood-red in autumn. Pkt., 10c.

\section{Lantana}

There is no plant which makes more show, and which gives more blooms and satisfaction in some corner of the yard, side of the house or any sunny, hot place, where nothing else will grow. Best mixed. Pkt., 10c.

\section{Larkspur}

Dwarf German Rocket.-Finest double mixed. Pkt., 10c. Double-Stock Flowering.-Purple, rose, flesh, blue, white, or mixed. A tall, branching variety, with beautiful long spikes of flowers. Pkt., 10c.

\section{Pansies}

We secure our pansy seed from the best American, French and European growers, and offer as fine a quality as can be grown.

King Rufus.-Fine bright red. Pkt., 10c.

President Wilson.-Large size; beautiful blue shade; gradually deepening to a purple color. Pkt., 10c.

Snow Queen.-Handsome pure white flowers. Pkt., 10c. Faust.-Rich, deep black. Pkt., 10c.

King of Yellows.-Clear yellow flowers. Pkt., 10c.

Finest Mixed.-Different shades and colors. Pkt., 15c.

English Show, Mixed.-All the richest and most delicate colors. Pkt., 20c.

Cassier's Mixed.-Blossoms are of enormous size and are most beautifully blotched, marked and striped; an inconceivable variety of colors. Pkt., 25c.

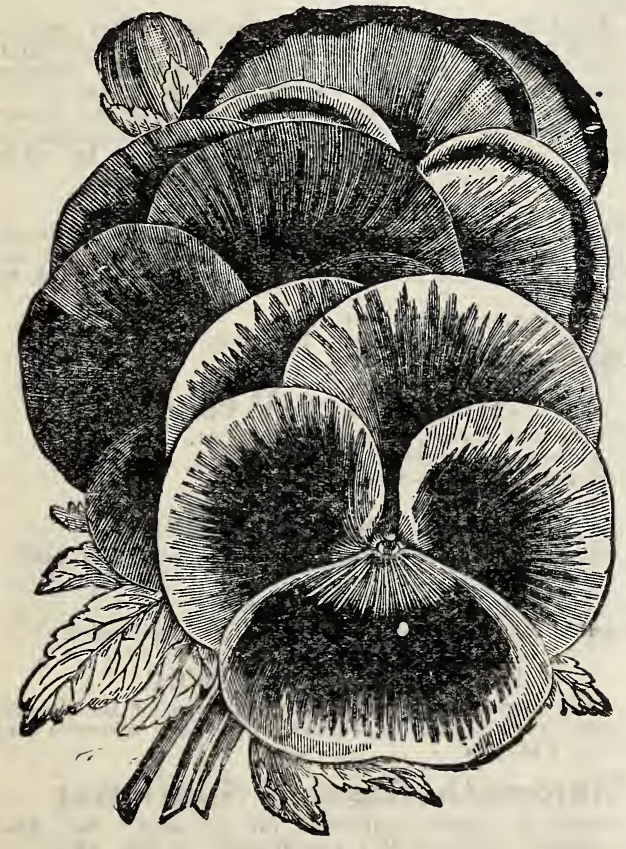

ENGLISH SHOW PANSIES

\section{Marigold}

Large African.-Tall, double; orange, brown and yellow mixed. Pkt., 10c.

Dwarf French.-Fine color. Mixed. Pkt., 10c.

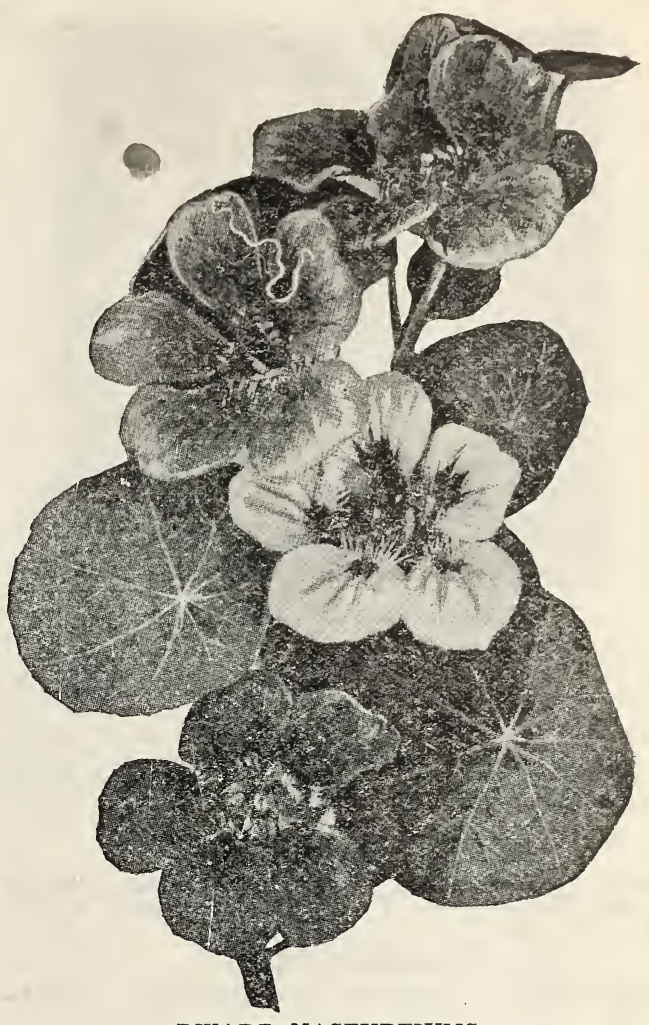

DWARF NASTURTIUMS

\section{Nasturtiums, Dwarf}

Free-flowering and very desirable for bedding, vases and pot plants. These come in all shades and colors assorted. Pkt., 10c; oz., 20c; $1 / 4$ lb., 50c.

\section{Nasturtiums, Tall}

Choice mixture of the finest varieties; 6 to 10 feet. Pkt., 10c; oz., 15c; 1/4 lb., 40c.

\section{Mignonette}

The fine old variety with small spikes of delightfully scented flowers. Pkt., 5c.

\section{Phlox}

For a splendid mass of colors and a constant display this is not excelled by any other annual.

Drummondi.-Its color ranges from purest white to bloodred or crimson. Finest mixed, all colors. Pkt., 10c; oz.. $\$ 1.00$.

Drummond Grandiflora.-These are a decided improvement on the old class, with larger flowers, a better range of colors and more compact growth. Pkt., 15c; oz., \$1.25.

\section{Portulaca}

A dazzling display of beauty; multi-colored. Double Mixed.-All colors. Pkt., 10c. Single Mixed-All colors. Pkt., 10c.

\section{Petunias}

We now have superb show varieties, fringed and ruffled and doubled. mottled, striped and self-colored. SINGLE.

Single Inimitable.-Striped and blotched. Very effective. Pkt.. 10c.

Large Flowered, Single Fringed.-A choice mixture from superb strains. Pkt., 25c.

Rose.-Fine pink. Pkt., $10 \mathrm{c}$

Good Mixed.-Pkt., 10c. 


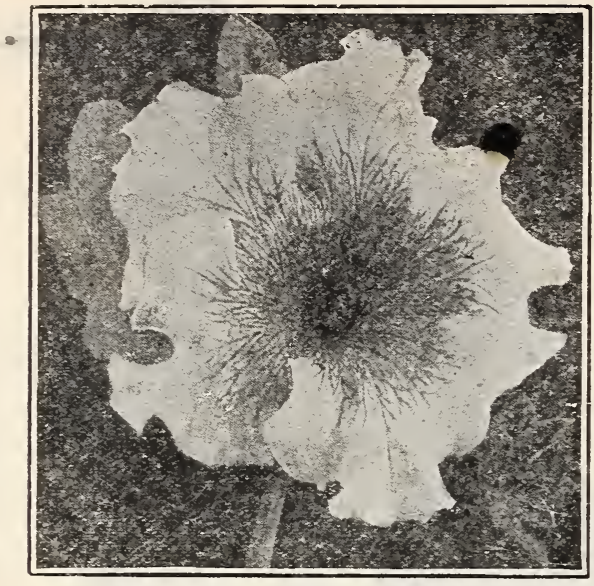

SINGLE FRINGED PETUNIAS

DOUBLE.

Large Flowered, Double Fringed.-All the best colors. Pkt., 30c.

Giants of California.-This is the largest strain of petunias ever sent out. The large, beautiful, fluffy blossoms are handsomely cr mpled, fringed and ruffled and come in white rose, velvety crimson-black, etc. Pkt., 25c.

\section{Pyrethrum}

Aureum (Golden Feather).-Bright yellow foliage. Pkt., 10c. Roseum (Persian Insect Powder Plant).-Flowers a bright rose. Pkt., 10c.

\section{Snapdragon}

One of the most showy and useful yard plants. Pkt., 10c.

\section{Verbena}

Scarlet.

The Most Popular Flower for the Yard.

Blue.-Purple and blue.

Mixed.-Finest colors.

Pink.-Deep pink.

White.-Pure white.

Above varieties, each, Pkt., 10c.

\section{Poppies}

Very Attractive Plants for Beds, Edgings or Masses. Carnation-Flowered (Double Annual Sorts).-Splendid double fringed flowers. Mixed colors. Pkt., 10c.

Peony-Flowered,-Large, showy, double globular flowers: well adapted for shrubbery, etc. Mixed colors. Pkt., 10c.

Shirley. - The range of colors is so varied that scarcely two flowers are alike; many are delicately edged and striped. Pkt., 10c.

Iceland (Nundicaule). - Hardy perennial sorts. Yellow, white or orange-scarlet flowers. Pkt., 10c.

Tulip-Flowered Scarlet.-Large, bright scarlet flowers. The two outer petals of the flower form a tulip cup. Strikingly beautiful. Pkt., 10c.

American Flag.-Large, showy bright flowers. Pkt., $10 \mathrm{c}$.

\section{California Poppy}

Profuse flowering, folisge fine cut; in bloom from June until frost. Flowers rich orange. Pkt., 10c.

\section{Sweet Peas}

Snowflake.-Large, pure white, improved white. Amethyst.-Royal purple.

Blanche Ferry.-Pink and white.

Canary Bird.-Large, cream.

Fordhook Rose.-Improved rose and carmine.

Illumination.-Salmon-cerise.

King Edward.-Deep maroon.

Asta Ohn.-Lavender.

Fiery Cross.-Bright red.

Mrs. Chas. Zvonenek.-Orchid.

Selma Swensen.-Soft pink.

Enchantress.-Pure rose-pink.

Pkt., 25c; oz., 50c; 1/4 lb., \$1.25; Ib., \$3.50.

Plant Sweet Pea seed from November 1st to February 28th.

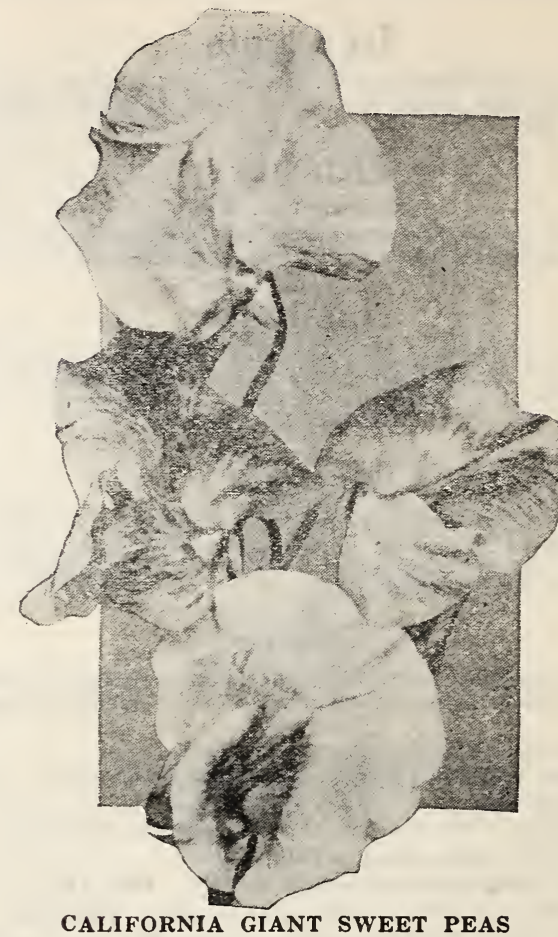

A Select List of Sweet Peas

Eckford's New Mixed.-This strain, although not embracing the latest novelties, contains a beautiful assortment of the famous Eckford Sweet Peas. Pkt., 10c; oz., 15c; 1/4 lb., 35c ; lb., \$1.25.

Gold Medal Mixture.-One of the most satisfactory ways of growing Sweet Peas is in a mixed row. Contains all bright varieties in proper proportions, mixed from many standard varietiss. Pkt., $15 \mathrm{c}$; oz., 20c; $1 / 4$ lb., 50c; lb., $\$ 2.00$.

California Giant Mixed. - The enormous size of the flowers and freedom with which they are produced recommend this mixture to all. Pkt., 25c; oz., 35c; 1/4 lb., 7jc; lb., $\$ 2.50$.

\section{Vinca (Periwinkle)}

The Vincas are among our most satisfactory bedding plants; they are very ornamental and bloom freely. In the fall they can be potted for the house, and kept in bloom through the winter.

Rosea.-Fine rose color. Pkt., 10c.

Rosea Alba.-White, rosy eye. Pkt., 10c.

All Colors.-Mixed. Pkt., 10c.

\section{Stocks, Ten-Weeks}

Large Flowered Dwarf.-Fine mixed. Pkt., 10c. Large Flowered Branching.-Mixed. Pkt., 10c. Cut and Come Again.-Mixed. Pkt., 10c.

\section{Scarlet Sage or Salvia}

Beautiful scarlet flowers. Best summer flower. Pkt., 10c.

\section{Sunflower}

Remarkable for the stately growth, size and brilliancy.

\section{New Red Sunflower}

The long, slender stems, the graceful poise of the flowers, with their varier coloring, make them very effective and desirable. Pkt., 10c.

\section{Mammoth Russian Sunflower}

This variety is largely cultivated for the seed. Pkt., 10c; price (prepaid), 35e per lb.; not prepaid, 10 lbs., \$2.25.

\section{Sweet William}

A beautiful free-flowering, bright-looking annual. Flowers star-shanod and come in all colors of the rainbow. Mixed colors. Pkt., 10c.

Single 10c Pkt.

Double 


\section{Zinnias, Dahlia Flowered}

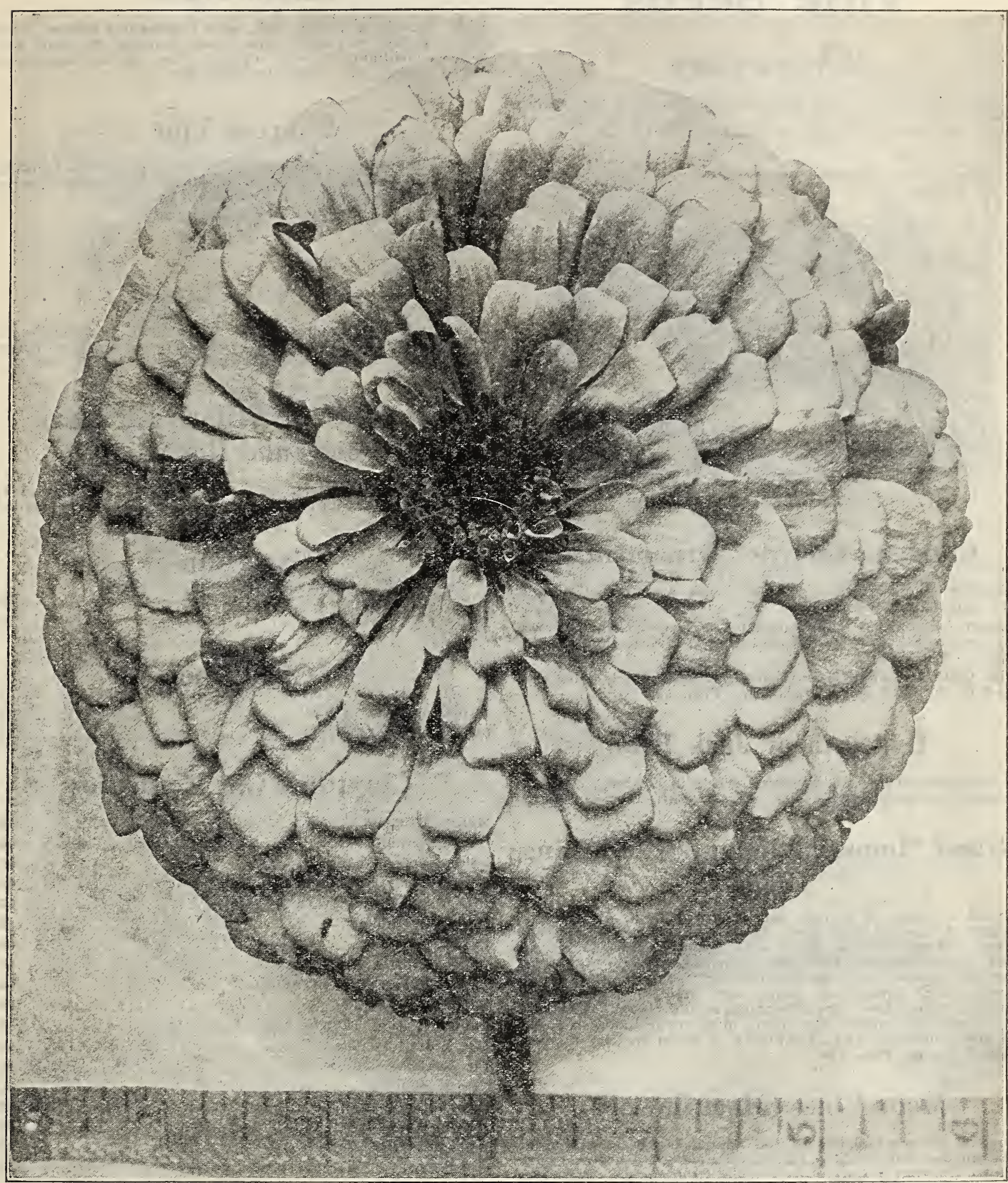

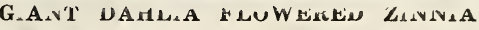

As its name indicates the DAHLIA FLOWERING ZINNIA resembles the Dahlia, flowers of ten measuring 6 to 12 inches, very hardy, being adapted to our climate. These may be had in separate colors or in mixed packages. There are NoNE BETTER to be had anywhere.

We offer all varieties as follows: Small pkt., 50c; large size, pkt., \$1.00, postpaid.

Exquisite L Light rose, center deep rose. Old Rose-Old rose shade. Golden State-Yellow, changing to orange, Crimson Monarch-Largest and best of the red shades. Meteor-Rich glowing deep dark red. Dream-Fine deep lavender changing to purple. Polar Bear-Best large, pure white. Buttercup-Immense deep creamy-yellow. Canary Bird-Delicate shade of primrose. Special Mixture-A well-blended mixture containing all of the above novelties.

Zinnias, Giant Double-A special strain of this grand old favorite. Under favorable conditions they remain in bloom from early summer to late autumn.
Mammoth Double Orange-Pkt., 10c. Mammoth Double Pink-Plt Mammoth Double Purple-Pkt., 10c. Mammoth Double Scarlet-Very bright, Pkt., 16c. Mammoth Double Red-Pkt., 10c. Mammoth Double White-Pkt., 10c. Mammoth Double Golden Yellow-Pkt., 10c. Mammoth Double Mixed-All colors, Pkt., 10c. Elegan's Double-This, we consider, the best type for general use, forming bushy compact plants not over two feet high, and bearing perfect double flowers. Mixed. Pkt., 10c, 25c; large pkts., 50c. 


\section{Vine Seeds}

\section{Morning Glory}

Tender annuals of rapid growth, with beautiful and varied lowers. For covering old walls, trellises, arbors, stumps of trees, they are invaluable; 15 to 20 feet. Pkt., 10c.

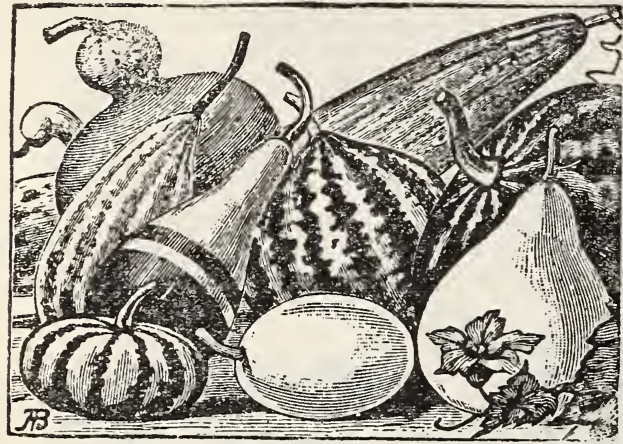

ASSORTED CLIMBING GOURDS

\section{Climbing Gourds-Ornamental}

Rapid-growing, interesting plants with ornamental follage and singular shaped fruit.

Dipper.-Useful for many household purposes. When grown on the ground, produce different shaped gourds than on the trellis. Pkt., 10c.

Dish Cloth or Luffa.-Sponge-like, porous lining is dried and used in the bath or for dishcloth. Pkt., 10c.

\section{Hyacinth or Jack Bean}

A rapid-growing plant, flowering freely in clusters; used for covering arbors, trellises, etc. Mixed. Pkt., 10c; oz., 15c.

\section{Grand "Imperial Japanese" Morning Glory}

Grand climbers of strong and robust growth, attaining a height of from 30 to 50 feet. Some are of deep rich, velvety tones, others daintily tinted and shaded, crimson. bronze and garnet-maroon; from the daintiest blue to the ultramarine, indigo and blackish-purple; from snow-white to cream and silver-gray. Some are striped, starred and spotted, others have magnificent edges and throat. They are of the earliest culture. Sow early in a warm, sunny position in good, rich soil, and give plenty of water in dry summer. Mixed colors. Pkt., 10e.

\section{Moon Vines (Moonflower)}

One of the most showy of the annual climbers. At night and during dull days the plants are covered with large, pure white, fragrant flowers, 5 to 6 inches in diameter. Pkt., 10c.

\section{Scarlet Runner Beans}

A rapid-growing annual climber, bearing sprays of brilliant scarlet pea-shaped blossoms. Used either as a snap or shell bean for eating as well as being desirable for ornamental purposes. Pkt., 10c.

\section{Balloon Vine}

A rapid-growing plant; succeeds best in light soil and warm situation; flowers white. Half-hardy annual; 5 to 15 feet. Pkt., 5c.

\section{Balsam Apple}

Very vigorous climbing vines, with ornamental foliage; fruit golden yellow. and when ripe opens, showing the seeds, and also its brilliant carmine interior; fine for trellises, rockwork, stumps, etc. Pkt., 10c; oz., 50c.

\section{Cypress Vine}

One of our most popular vines, with very delicate fern-like foliage, and masses of beautiful, small star-shaped flowers. Mixed white and crimson. Pkt., 10c: oz., 35c.

Red.-A beautiful shade of red. Pkt., 10c.

White.-A beautiful white, Pkt., 10c.

\section{Cardinal Climber}

The finest new annual climber introduced in many years. Bespangled with clusters of fiery scarlet, tubular, spearshaped flowers, measuring $1 \frac{1}{4}$ inches across. Pkt., 10c.

\section{Dr. Hess' and Clark's Poultry Foods and Remedies}

Prices quoted are f. o. b. Los Angeles. If wanted by mail, add postage at zone rates. Liquids cannot be mailed.

\section{Cage Cups}

No. $1904-$ Flint Glass.........................25c

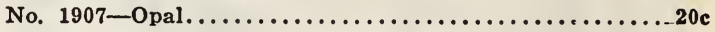

\section{Cage Hook}

10-inch Brass or Nickel.......................... 12-inch Brass or Nickel......................50

\section{Clayton's Cat Remedies}

Mange Remedy..............................60

Distemperine ............................6.

Distemperine Tablets ........................60

Tonic Catnip and Condition Tablets..............60

Blood Purifier and Cooling Tablets................60

Digestive Tablets..........................6.

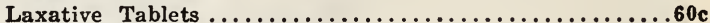

Worm Tablets.............................60c

Tape Worm Expeller Tablets..................6.

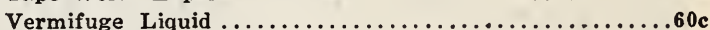

Canker Lotion Tablets.....................6.

Eye Lotion Tablets.........................60

Fit Tablets...............................6.

Cough Remedy .............................60

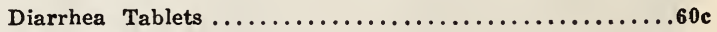

Mouth Wash ...............................60

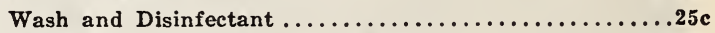

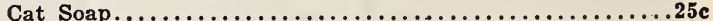

\section{Acme 2-Way Spray}

This very effective and approved formula, containing $14 \%$ Arsenate of Lead and $83 \%$ Bordeaux Mixture, enables you to kill two birds with one stone. It will control all leafeating or chewing insects and at the same time the Bordeaux Mixture will control and prevent many of the fungus diseases that the average amateur gardener does not know are present. Acme 2-Way Spray is a powder to be mixed with water when used as a spray material, or it may be used as a dust. Bordeaux Mixture stimulates plant growth and it is, therefore, an important addition to the 2-Way Spray. (1/2-lb. carton 25c); (1-lb. carton 45c); (4-lb. paper bag $\$ 1.25)$; f. o. b. Los Angeles. Can not be mailed. 


\section{Insecticides-Spray Materials}

\section{Destruxol}

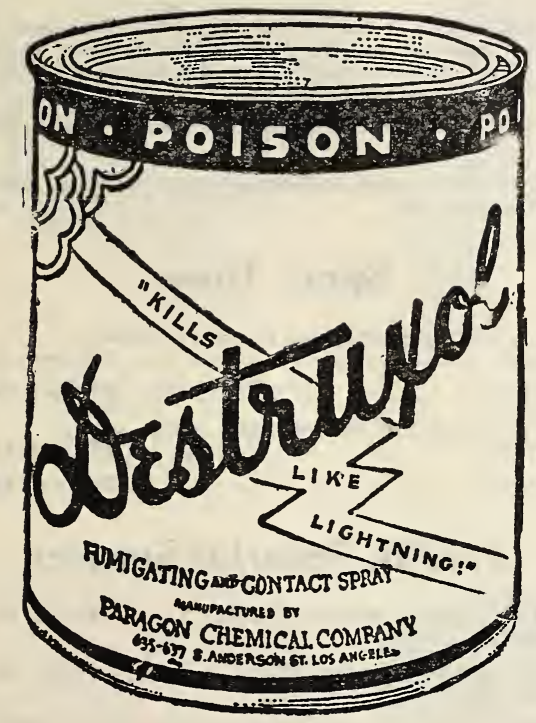

This combination spray, containing Nicotine Sulphate and Cyanide, seems to be what we have been after for some time. making it possible through the fumes given off by the Cyanide to reach insect life on the under side of foliage. Our tests have shown it effective when used at proper temperatures and conditions against such common garden pests as aphids, thrip, lice, red spider, leaf roller hoppers, mildew and mealy bug. It is most effective under temperatures of $70^{\circ}$ degrees and above, the warmer the weather the better, as the fuming action is greater under higher temperature. Our tests of this product would indicate higher temperature. Our tests of this product would indicate though used at double strength. Use 1 large teaspoonful of Destruxol to 1 gallon of water.

1 oz. makes 5 gallons of spray.......... $\$ 40$

$1 / 4$ pt. makes 25 gallons of spray............90

$1 / 2$ pt. makes 50 gallons of spray........... 1.40

1 pt. makes 100 gallons of spray........... 2.00

1 qt. makes 200 gallons of spray.......... 3.75 Must be sent via express.

\section{Black Leaf 40}

A 40 per cent. Nicotine solution for the control of plant lice or aphids on roses and other garden plants. Must be applied in vapor form with a spray pump. Black Leaf 40 will kill all aphids or plant lice that are covered with the spray material, but a new supply of aphids may be carried to your plants the following day by the Argentine Ant. To control aphids it is necessary also to control Argentine Ant. A one-ounce bottle of Black Leaf 40 will make 6 gallons of spray. Full directions on the package. (1 oz. bottle. 35c); (1/2 lb. tin, \$1.25); (2 lb. tin, \$3.50); (10 lb. tin, $\$ 13.50$ ). Sent by express or freight only.

\section{Cyanogas}

For Wireworm, Red Ant, Etc.

For the control of Wireworm plant a bait crop of beans, corn or peas, before the garden is planted, covering the bait crop to a depth of about 3 inches, in rows about 36 inches apart. Within one week the Wireworms will be attracted to the bait crop and at this time apply Cyanogas by means of a garden seeder or by similar method, directly into the
bait rows and about one inch below where the bait was planted. In the small garden, where no seeder is available, open a narrow trench deeper than the bait level, close to and on each side of the bait row, and apply Cyanogas at the rate of one pound to each 100 feet of row. Cover immediately with the earth dug from the trench and leave it for three to four days, after which time seeds or plants may be planted without injury to them. Remember that Cyanogas is injurious to growing plants and it must not be used except when there are no plants growing.

For field operations, where the bait rows are about three feet apart, it requires about 90 pounds of Cyanogas per acre. For further information ask for bulletin on Wireworm Control. 1 lb. package, 60c; 5 lb. package, $\$ 2.75$, f. o. b. Los Angeles. Cannot be mailed.

CYANOGAS A-DUST-For the control of large red ants, gophers, etc. $1 \mathrm{lb}$. package, $60 \mathrm{c} ; 5 \mathrm{lb}$. package, $\$ 2.75$.

\section{Acme Garden Guard}

So far as we know, Garden Guard is the only garden insecticide on the market containing Bordeaux Mixture. It is a convenient, practical and economical all-around garden insecticide, ready for use as it comes in the package; in a sifter can, easily applied, and very effective in combating the majority of insect pests that prey upon your garden. Applied early in the morning or late in the evening when the dew is on, it will control many chewing insects on vegetables shrubs and flowers. The Bordeaux Mixture contained therein serves as a fungicide and will assist in preventing Mildew and other fungus difficulties. Used extensively by market gardeners. $1 \mathrm{lb}$. package, $35 \mathrm{c} ; 5 \mathrm{lb}$. package, 90c; 100 lb. drum, \$15.75; 200 lbs., \$31.00, f. o. b. Los Angeles. Can not be mailed.

\section{Arsenate Lead}

1/2-lb. can ......................... 40

1-lb. can $\ldots \ldots \ldots \ldots \ldots \ldots \ldots \ldots \ldots \ldots \ldots, \quad .75$

\section{Dry Lime-Sulphur}

1-lb. can ........................... 50

All Spray Materials Shipped by Express, Collect.
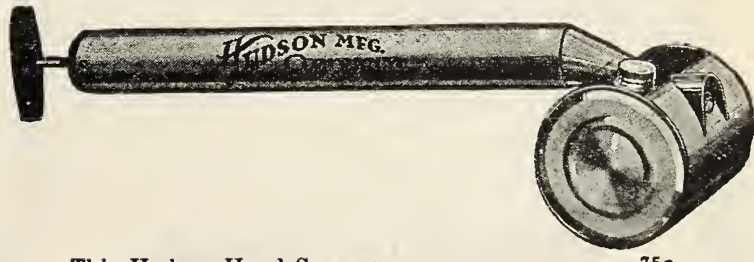

This Hudson Hand Sprayer............... 75e

Galvanized Continuous Sprayer...........\$1.25

\section{Lowell Junior Sprayer}

Fruit trees, shade trees, ornamentals and the garden in general mist be sprayed if best results are obtained. For all around general use on the small ranch this pump will be found most satisfactory. It will handle whitewash, water, paints, Bordeaux Mixture, Lime Sulphur, etc., and is used by many poultrymen for spraying their poultry houses and by many poultrymen for spraying their poulthort extension rod with angle fog nozzle. Easy to reach the underneath side of leaves and vines. Weight packed, 14 pounds.

Galvanized-\$7.50 each, f. o. b. Los Angeles.

Brass-\$10.50 each, $f$. o. b. Los Angeles.

Three-foot brass extension rod, $\$ 1.00$. 


\section{Lowell Compressed Air Sprayer}

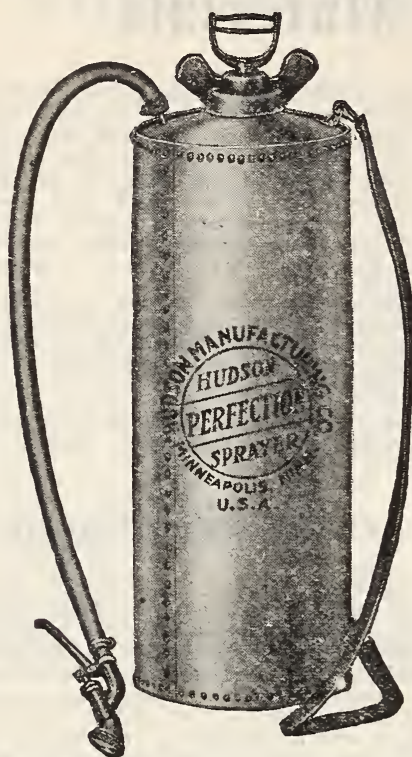

For the Hume Gardener and Poultryman

This is an inexpensive sprayer that makes spraying a pleasure and applies spray materials effectively. A home garden, trees and shrubs can be sprayed quickly and with the compressed air tank there is sufficient pressure to cover the plant thoroughly with a fine fog spray. Capacity is $2 \frac{1}{2}$ gallons. All working parts are brass and with proper care will last indefinitely. Price, $\$ 6.00, f$. o. b. Los Angeles.

\section{Continuous Sprayer No. 26}

We believe this is one of the very best continuous sprayers. The container may be detached for refilling and cleaning by simply unscrewing it from the pump cylinder. May be used for all spraying solutions. $10 \mathrm{c}$.

No. 26-C-All brass, capacity one quart, \$1.50. Postage,

No. 26-D-Tin pump, galvanized tank, capacity, one quart, \$1.10. Postage, 10c.

\section{Spray Hose}

\begin{abstract}
Heavy, high pressure hose for power pumps: $8 / 8$-inch...........................25 per foot $1 / 2$-inch............................. per foot

Five-ply hose for use on small spray pumps: $8 / 8$-inch........................17c per foot $\%$-inch............................. per foot
\end{abstract}

\section{A. \& M. Superior Sprayer}

Holds 1 quart. Weight, crated, 3 lbs. Price, 50c. By mail, $60 \mathrm{c}$.

Little Midget Sprayer-Holds 1 pint. Price, 40c. By mail, 50c.

\section{Bird Cages and Supplies}

PLAIN ENAMEL BIRD CAGES

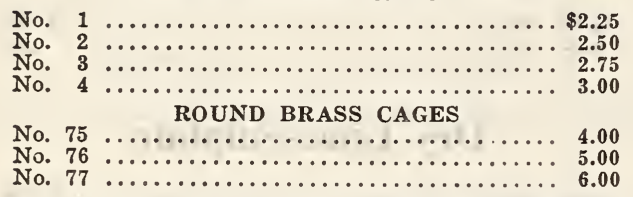

\section{Bird Food and Remedies}

Postage Extra on All Bird Supplies Canary Breeding and Train Book................

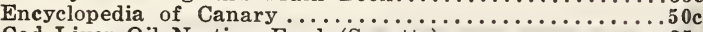
Cod Liver Oil Nesting Food (Spratts) ................25c Song Restorer..............................25c

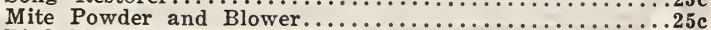

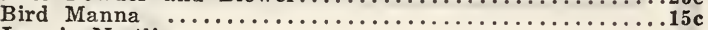

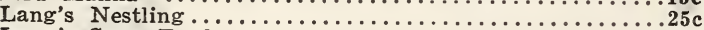

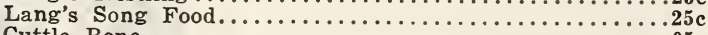

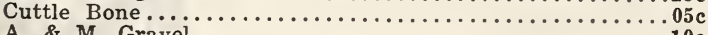

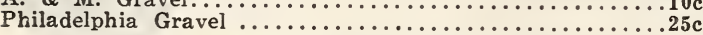

\section{Clayton's Dog Remedies}

(Postage Extra on All Dog and Cat Remedies and Supplies)

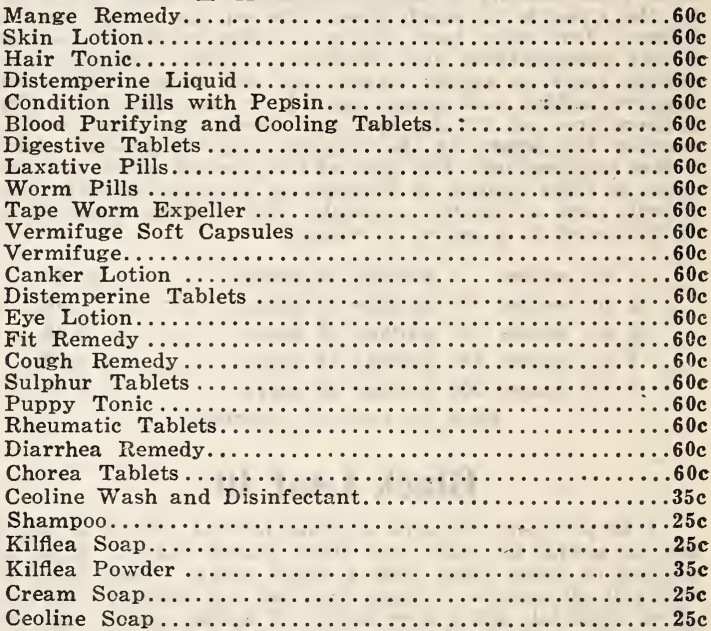

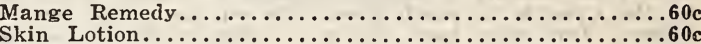

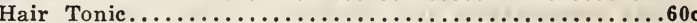
Distemperine Liquid .......................60

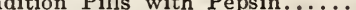
Blood Purifying and Cooling Tablets . . .

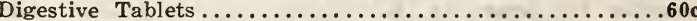
Worm Pills Tape Worm Expeller ........................60 Vermifuge Soft Capsules $\ldots \ldots \ldots \ldots \ldots \ldots \ldots$ Vermifuge. Canker Lotion

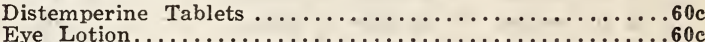
Fit Cough Remedy .

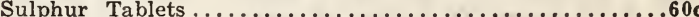
Puppy Tonic..........60 Diarrhea Remedy

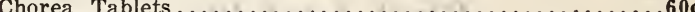

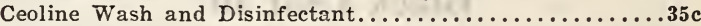
Kilfea Soap

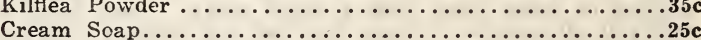

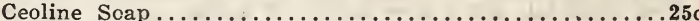

\section{WE ARE BIG GROWERS OF VEGETABLE PLANTS}

We are the largest growers of vegetable plants in the South. Over one million Frost-proof Cabbage Plants now ready for early gardens. We can supply your needs in Egg, Pepper, Tomato, and Sweet Potato Plants, all grown from highest quality seed. Place your orders early; we will make shipment when you desire.

\section{POTATO SLIPS READY ABOUT APRIL IST}

Every year we grow for our trade about 10,000 Pumpkin Yam potato slips. The price varies according to season. March delivery, $10 \mathrm{c}$ per dozen, 50c per $100 ; \$ 5.00$ per 1,000 . April delivery, $\$ 4.50$ per 1,000 . TOMATOES READY ABOUT MARCH 1ST

For early planting try some of our fine and true plants grown from selected seeds. Dwarf, Champion (tree Tomato), Acme (tall variety), also Beauty and Stone. Price, $10 \mathrm{c}$ per dozen; 50c per $100 ; \$ 3.50$ per 1,000 .

\section{CABBAGE READY ABOUT FEBRUARY 1ST}

Thousands of these plants are grown by us for early planting, such varieties as Early Jersey Wakefield, Early Winningstadt, Early Summer. Prices, $10 \mathrm{c}$ per dozen, 50c per $100 ; \$ 3.50$ per 1,000 .

Place orders early, as they are always short. 20c per dozen; 2 dozen, 35c; $75 \mathrm{c}$ per 100. 


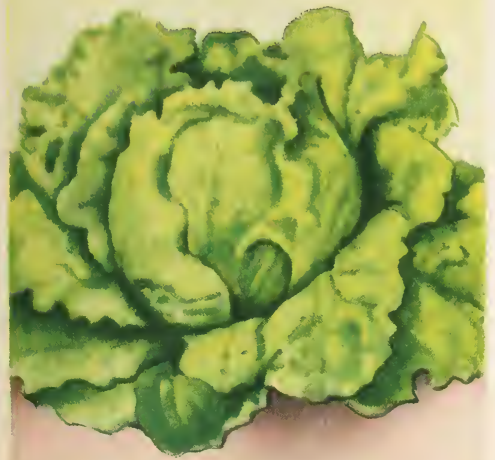

Lang's Butterhead Lettuce. The Family Delight. Pkg. 15c

\section{CANTALOUPE}

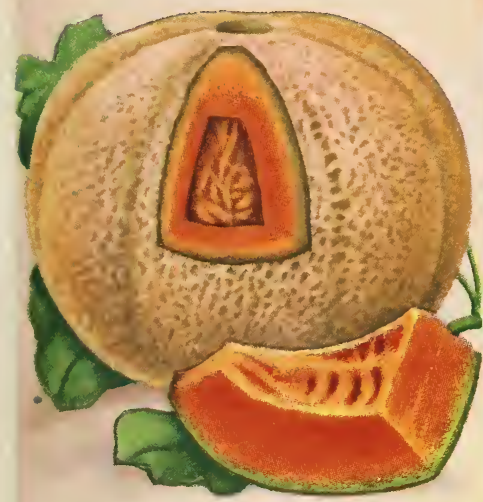

Lang's Gold Lined.

Netted Rock Family Favorite. Pkg. 15c RADISH

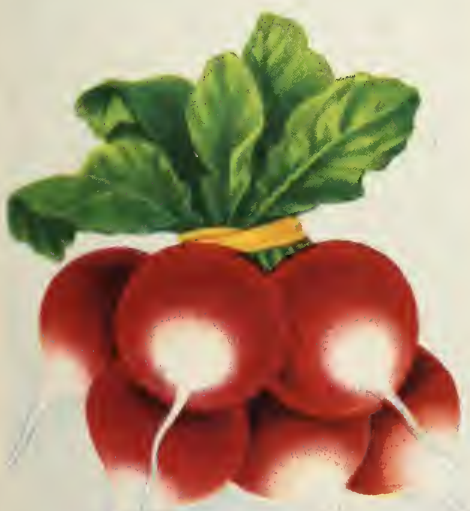

Lang's Home Delight. Early Select White Top. Pkg. 15c

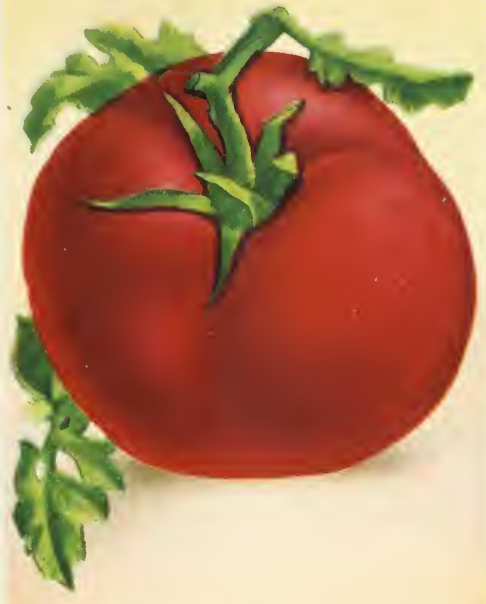

Red Beauty Dwarf. Lang's Prize Tomato. Pkg. 15c BEET

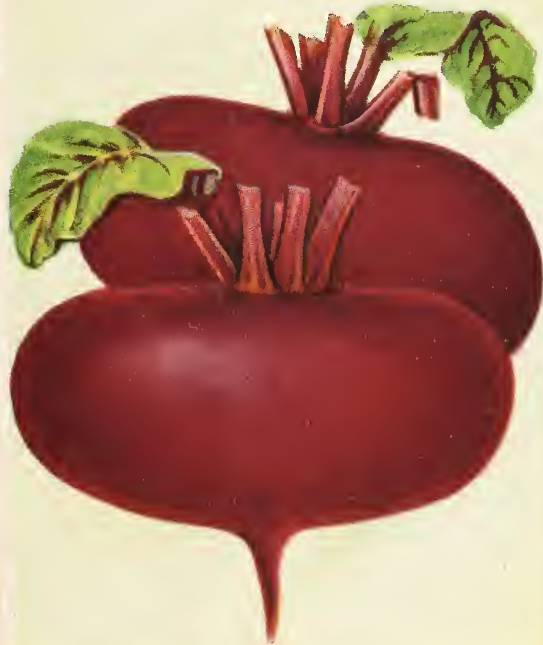

Lang's Extra Early Table Favorite. Pkg. 15c

\section{WATERMELON}

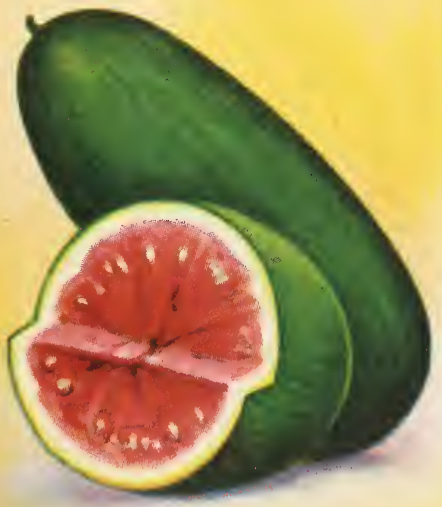

Lang's Family Favorite. Improved Kleckley Sweet $\mathrm{Pkg}$. $15 \mathrm{c}$

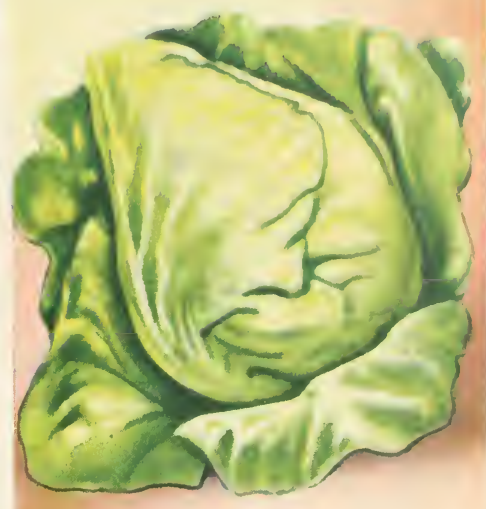

Lang's Improved Early. Jersey Wakefield Cabbage. Pkg. 15c TURNIP

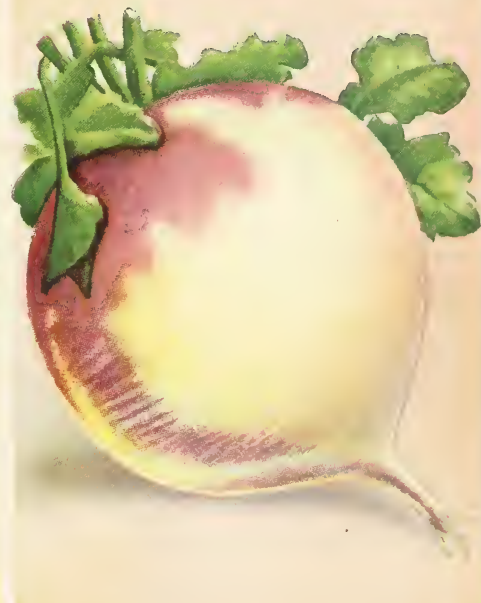

Lang's Special Grown.

Purple Top White Globe. Pkg. 15c

\section{CARROT}

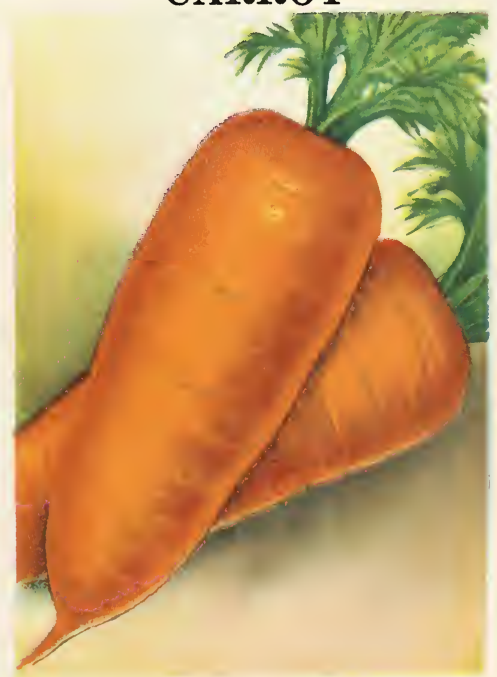

Lang's Improved. Special Extra Full Half Long. Pkg. $15 \mathrm{c}$ 


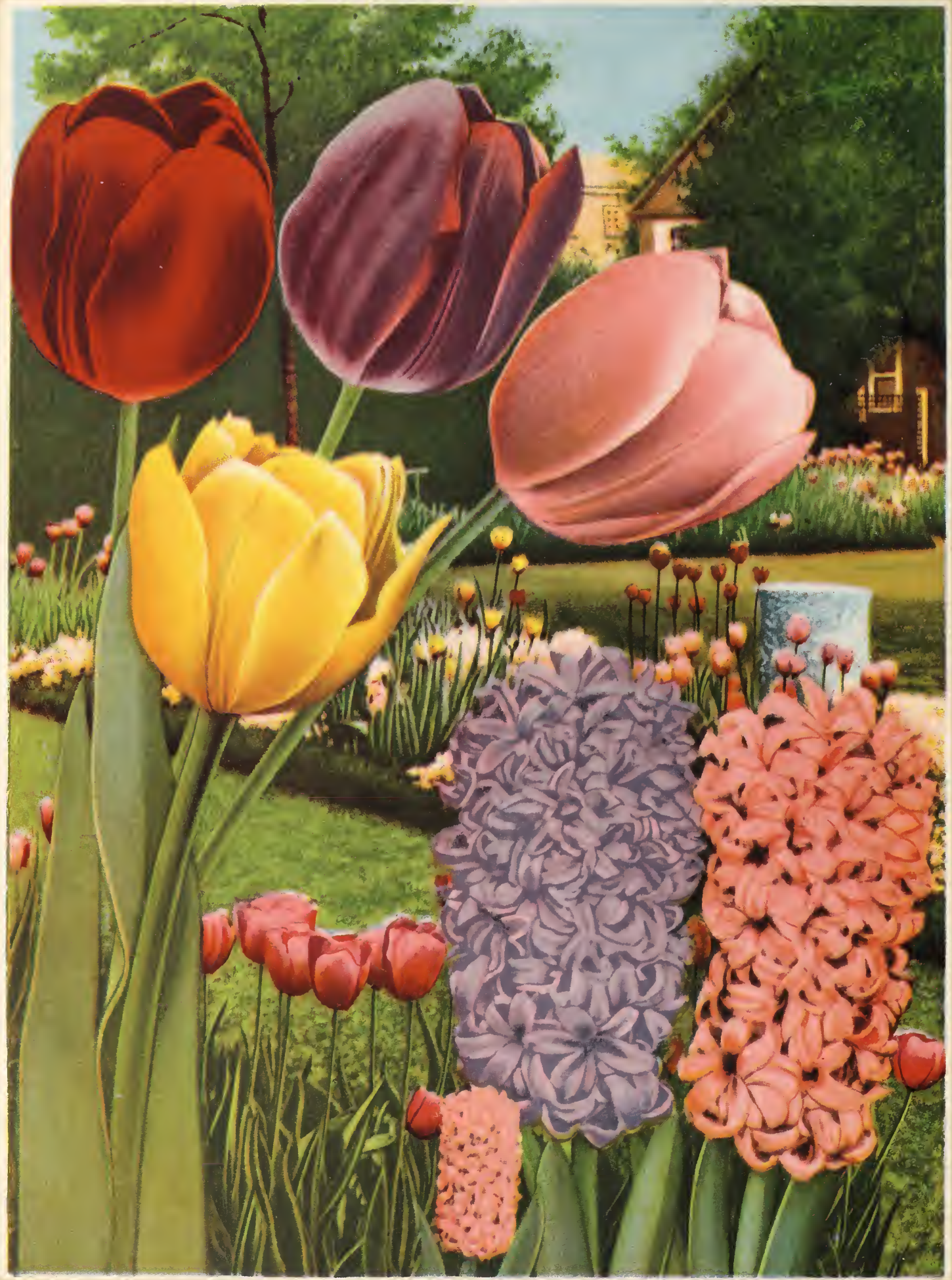

\section{DARWIN TULIPS}

Lang's Special

Finest Red Bedder

Faircombe Sanders Improved......... Violet

Reverend Eubank Extra Select..............

Pride of Harlem

Best Yellow Tulip Grown

Inglescombe Special Select

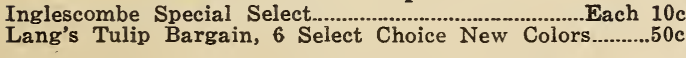

Each $10 \mathrm{c}$ Each $10 \mathrm{c}$

Each $10 c$

Each 10

\section{LANG'S HYACINTH Special Select} Queen of the Blues

Monster Bulbs...........

Finest Pink; Mammoth Bulbs....................

Gertrude Lang's Pride

Fine Bloomer; Large Bulbs.......................

6 Extra Select Single and Double..

12 Special Select Single and Double.
Each 25c

Each $25 c$ Each $15 c$

$\$ 1.50$ 2.75 